\title{
Flora da Bahia: Menispermaceae
}

\author{
Michella Del Rei Teixeira ${ }^{1 *} \&$ André Márcio Araújo Amorim²,3
}

${ }^{1}$ Universidade Estadual de Feira de Santana, Departamento de Ciências Biológicas, Av. Transnordestina, s/n, Novo Horizonte, 44036-900, Feira de Santana, Bahia, Brasil.

${ }^{2}$ Departamento de Ciências Biológicas, Universidade Estadual de Santa Cruz, Km 25 Rodovia Ilhéus-Itabuna, 45662-000, Ilhéus, Bahia, Brasil.

${ }^{3}$ Herbário CEPEC, CEPLAC, C.P. 07, Km 22, Rodovia Ilhéus-Itabuna, 45600-970, Ilhéus, Bahia, Brasil.

\begin{abstract}
Resumo - É apresentado o levantamento florístico de Menispermaceae da Bahia, Brasil, como contribuição ao conhecimento da flora do estado. Foram reconhecidos 22 táxons, sendo apresentadas chaves analíticas de identificação, descrições, comentários, mapas de distribuição e ilustrações das espécies. São fornecidas pela primeira vez a descrição e ilustração de caracteres reprodutivos de Curarea crassa (flores fem.), Odontocarya duckei (flores masc.) e Sciadotenia pubistaminea (frutos). Abuta selloana e Disciphania ernstii representam novos registros para a Bahia. Uma espécie de Cissampelos permanece não identificada, mas suas afinidades morfológicas são aqui discutidas.

Palavras-chaves adicionais: Chondrodendron, Cissampelos, florística, Nordeste brasileiro, taxonomia.
\end{abstract}

\begin{abstract}
Flora of Bahia: Menispermaceae) - A floristic survey of Menispermaceae from Bahia, Brazil, is presented as a contribution to the study of the State flora. Twenty-two taxa are recognized and identification keys, descriptions, comments, distribution maps and illustrations of the species are provided. Descriptions and illustrations of reproductive characters of Curarea crassa (female flowers), Odontocarya duckei (male flowers) and Sciadotenia pubistaminea (fruits) are provided for the first time. Abuta selloana and Disciphania ernstii are recorded for the first time in Bahia. One species of Cissampelos remains unidentified, but the morphological affinities with other species are discussed.
\end{abstract}

Additional key words: Chondrodendron, Cissampelos, floristics, Northeastern Brazil, taxonomy.

\section{Menispermaceae}

Lianas, às vezes arbustos eretos ou escandentes, raramente ervas ou árvores, perenes; caule cilíndrico ou achatado, tricomas simples; estípulas ausentes. Folhas alternas, geralmente simples, às vezes peltadas, pecioladas; venação geralmente palmatinérvea, com 3-12 nervuras principais, às vezes peninérvea. Inflorescências estaminadas e pistiladas axilares a supra-axilares ou caulifloras, geralmente racemosas, paniculadas, tirsiformes, algumas vezes cimosas no ápice, raro flores solitárias ou aos pares. Flores pequenas, unissexuadas (plantas dioicas), mono ou diclamídeas. Flores masculinas com sépalas (1)3-12 ou mais, livres ou conatas, em 2 ou mais séries; pétalas menores que as sépalas, 1-6 ou ausentes, livres ou conatas; estames (1-)3-6 ou mais, livres ou conatos (sinândrio), anteras com deiscência rimosa ou transversal. Flores femininas com sépalas e pétalas geralmente como nas flores masc., menos numerosas e ramificadas; estaminódios presentes ou ausentes; gineceu apocárpico, carpelos 3, 6 ou mais raro 1, estigma terminal, inteiro ou lobado, ovário súpero, óvulos 2 por lóculo, 1 abortivo, placentação pêndula. Frutos drupáceos, frutículos 1-6, com estípite ou não, com ou sem carpóforo; epicarpo coriáceo ou membranáceo; mesocarpo mucilaginoso, carnoso ou fibroso; endocarpo fibroso, lenhoso ou coriáceo, raro cartilaginoso, superfície rugosa, sulcada ou tuberculada, muitas vezes com uma intrusão do endocarpo (côndilo); semente reta ou curvada sobre o côndilo, com ou sem endosperma.

Menispermaceae está incluída na ordem Ranunculales e possui distribuição pantropical, com poucas espécies ocorrendo em regiões temperadas (Jacques et al. 2007; Judd et al. 2007). A família possui oito tribos com aproximadamente 70 gêneros e mais de 500 espécies (Diels 1910; Barneby \& White 2004). Para o Brasil, são referidos 16 gêneros (2 endêmicos), 110 espécies (26 endêmicas), seis subespécies e sete variedades, ocorrendo em todos os estados (Braga 2010). Na Bahia, Menispermaceae está representada por 12 gêneros e 22 espécies.

\section{Chave para os gêneros}

\section{Planta estaminada.}

2'. Folhas com venação peninérvea.

3. Flores com pétalas planas...

3'. Flores com pétalas formando um pseudodisco

2. Folhas com venação palmatinérvea.

*Autora para correspondência: michelladelrei@yahoo.com.br 
4. Perianto e androceu 4-meros; pétalas presentes, conatas; estames conatos formando um sinândrio....... 5. Cissampelos

4'. Perianto e androceu 3-meros; pétalas presentes ou não, livres, conatas apenas na base ou até a metade do comprimento; estames livres ou levemente conatos, raro em sinândrio.

5. Sépalas $9-18$, em 4 ou mais séries.

6. Lâmina foliar concolor, verde, face abaxial glabra a pubescente

11. Sciadotenia

6'. Lâmina foliar discolor, face adaxial verde, face abaxial geralmente alva, densamente tomentosa.

4. Chondrodendron

5'. Sépalas 6 ou 9 , em 2 ou 3 séries.

7. Pétalas ausentes

1. Abuta

7'. Pétalas presentes.

8. Lâmina foliar discolor, face abaxial velutina a tomentosa

6. Curarea

8'. Lâmina foliar concolor, ambas as faces glabras ou levemente pubescentes.

9. Pétalas carnosas, planas ou involutas.

10'. Sépalas conatas na base ou até a metade do comprimento; pétalas planas; estames $3(-6)$.

10. Sépalas livres; pétalas involutas, abraçando completamente cada estame; estames 6 .

7. Disciphania

11. Folhas com nervuras principais laterais salientes na face abaxial; pétalas maiores que os estames ...

2.Anomospermu

11'. Folhas com nervuras principais laterais não salientes na face abaxial; pétalas iguais ou menores que os estames

10. Orthomene

9'. Pétalas membranáceas, levemente involutas ou revolutas.

12. Sépalas 9

3. Borismene

12'. Sépalas 6.

13. Estames (3-5)6, livres

8. Hyperbaena

13 '. Estames 1,3 ou 6 , conatos, raro livres

9. Odontocarya

1'. Planta pistilada.

14'. Folhas com venação peninérvea.

15. Flor com 6 estaminódios; sementes com endosperma

12. Telitoxicum

15'. Flor sem estaminódios; sementes sem endosperma

8. Hyperbaena

14. Folhas com venação palmatinérvea.

16. Carpelo 1

5. Cissampelos

16'. Carpelos 3 ou 6.

17. Sementes sem endosperma.

18. Carpelos 3.

19. Lâmina foliar discolor, face abaxial densamente velutina a tomentosa; flor fem. com 3 pétalas; drupas com carpóforo, geralmente curto .

6. Curarea

19'. Lâmina foliar concolor, face abaxial glabra a pubescente; flor masc. com 6 pétalas; drupas sem carpóforo.

8. Hyperbaena

18'. Carpelos 6.

20. Lâmina foliar discolor, face abaxial geralmente alva, densamente tomentosa; drupa com estípite até $1 / 4$ do comprimento do fruto

4. Chondrodendron

20'. Lâmina foliar concolor, face abaxial glabra a levemente pubescente; drupa com carpóforo.

11.Sciadoteni

17'. Sementes com endosperma.

21. Endosperma ruminado.

22. Pétalas ausentes; endosperma em forma de U invertido

1. Abuta

22'. Pétalas presentes; endosperma em forma de J ou linear.

23. Endosperma em forma de $\mathbf{J}$

23 '. Endosperma linear

2. Anomospermum

21'. Endosperma liso.

10. Orthomene

24. Flor com 9 sépalas; drupa com endocarpo cartáceo

3. Borismene

24 '. Flor com 6 sépalas; drupa com endocarpo cartilaginoso a crustáceo.

25. Endocarpo com costa lobada, mais ou menos saliente; côndilo ausente

7. Disciphania

$25^{\prime}$. Endocarpo sem costa; côndilo presente

9. Odontocarya 
1. Abuta Barrère ex Aubl.

Lianas, arbustos escandentes, raro árvores. Folhas simples; pecíolo inserido na base; lâmina oblonga, lanceolada, oval a cordiforme; venação palmatinérvea, nervuras principais 3 ou 5. Inflorescência estaminada axilar a supra-axilar, racemosa, 6 paniculada ou tirsiforme; brácteas diminutas. Flores masc. geralmente monoclamídeas, sésseis a pediceladas; sépalas 6, em 2 séries, livres, pubescentes, as 3 externas menores e bracteiformes; pétalas ausentes, estames 6 , filetes livres ou os 3 internos conatos, anteras com deiscência rimosa ou transversal. Inflorescência pistilada axilar a supra-axilar, espiciforme, racemosa ou paniculada, geralmente mais curta que a masc.; brácteas diminutas. Flores fem. com perianto semelhante ao das masc.; estaminódios (3-)6; carpelos 3, sésseis, estigma simples a bífido, subulado, recurvado. Drupa com estípite ca. $5 \mathrm{~mm}$ compr., oblonga a ovoide com contorno quase simétrico, levemente comprimida lateralmente; epicarpo geralmente coriáceo; mesocarpo delgado ou ausente; endocarpo em forma de $\mathrm{U}$ invertido, coriáceo, reticulado ou lenhoso, côndilo não visível externamente, intrusão lateral, lameliforme; semente curvada, endosperma ruminado.

Abuta está posicionado na tribo Anomospermeae Miers (Diels 1910; nome corrigido em Forman 1982) e inclui ca. 32 espécies de distribuição neotropical (Krukoff \& Barneby 1970a; Ortiz 2001). No Brasil, Abuta está representado por 16 espécies distribuídas em todos os estados das Regiões Norte e Sudeste, e em estados do Nordeste, Centro-Oeste e Sul (Barneby \& Krukoff 1971; Krukoff \& Barneby 1974; Krukoff 1982; Barneby 1996; Braga 2010). Na Bahia, Abuta esta representado por duas espécies.

\section{Chave para as espécies}

1. Planta estaminada.

2. Lâmina foliar largamente elíptica ou cordiforme, face adaxial glabra, abaxial pubescente, nervuras principais 5; flores com sépalas internas 2,2-2,4 × 1,2-1,8 mm, estames 1,3-1,5 mm compr. 1.1. A. convexa

2'. Lâmina foliar lanceolada, ambas as faces glabras, nervuras principais 3 ; flores com sépalas internas $1-1,2 \times 0,8-0,9 \mathrm{~mm}$, estames ca. 0,8 mm compr. 1.2. A. selloana

1'. Planta pistilada, com fruto.

3. Lâmina foliar largamente elíptica ou cordiforme, face adaxial glabra, abaxial pubescente, nervuras principais 5; drupa velutina ............................. 1.1.A. convexa

3'. Lâmina foliar lanceolada, ambas as faces glabras, nervuras principais 3; drupa glabra......1.2. A. selloana

1.1. Abuta convexa (Vell.) Diels in Engler, Pflanzenr. 4(94): 193. 1910.

Figuras 1A-E e 2.

Liana ca. 2 m alt. Folhas cartáceas; pecíolo (3,5-)5-15 cm compr., pulvino levemente torcido no ápice; lâmina 10 $20 \times 11-18 \mathrm{~cm}$, largamente elíptica, cordiforme, base subcordada a arredondada, raro truncada, margem inteira, revoluta, ápice arredondado a mucronado, face adaxial convexa, raro plana, glabra, abaxial pubescente; nervuras principais 5. Inflorescência estaminada em racemo composto; raque 4-28 cm compr., densamente pubescente (Folli 2808). Flores masc. creme; pedicelo 5-10 mm compr., pubescente; sépalas cartáceas, margem inteira, ápice acuminado, as externas $0,9-1,2 \times 0,5-1 \mathrm{~mm}$, ovadas, as internas 2,2-2,4 $\times$ $1,2-1,8 \mathrm{~mm}$, oblanceoladas a ovadas, levemente revolutas na antese; pétalas ausentes; estames 1,3-1,5 mm compr., livres, anteras extrorsas (Folli 2808). Inflorescência pistilada em racemo simples; raque 4-16 cm compr., pubescente (Krukoff \& Barneby 1974). Flores fem. não observadas. Drupa 25-30 × 15-20 mm, 11-15 mm espessura, oblonga, velutina, imatura oliva, madura amarelo-pálida a laranja; endocarpo ca. $21 \times 13 \mathrm{~mm}$, reticulado; semente ca. $18-20 \times$ 10-12 mm.

Endêmica da Mata Atlântica brasileira, sendo distribuída em estados das Regiões Nordeste e Sudeste (Barneby \& Krukoff 1971; Barneby 1996; Braga 2010). G8, I8, J8: Floresta Ombrófila Densa. Coletada com frutos de junho a setembro.

Material selecionado - Camacan, $15^{\circ} 23^{\prime} 35^{\prime \prime} \mathrm{S}, 39^{\circ} 33^{\prime} 53^{\prime \prime} \mathrm{W}$, 26 mar. 2009 (est.), D.S.B. Rocha et al. 1025 (CEPEC); Ilhéus, 1446’38'S, 3905'28'W, 28 set. 1994 (fr.), W.W. Thomas et al. 10733 (CEPEC, HUESC); Prado, 12 ago. 1995 (fr.), G. Hatschbach et al. 63017 (CEPEC, MBM); Santa Cruz Cabrália, 16²3'36”S, 39¹0'32’'W, 19 jun. 2004 (fr.), V.C. Souza 29953 (ESA).

Material adicional examinado - ESPÍRITO SANTO: Linhares, 17 fev. 1983 (fl. masc.), D.A. Folli 2808 (CVRD n.v., $\mathrm{RB})$.

Abuta convexa distingue-se das demais espécies estudadas principalmente por apresentar lâmina foliar largamente elíptica ou cordiforme, com face adaxial convexa (raro plana) e glabra e face abaxial pubescente, com cinco nervuras principais.

\subsection{Abuta selloana Eichler, Flora 47: 389. 1864.}

Figuras $1 \mathrm{~F}-\mathrm{J}$ e 2.

Liana 5-8 $\mathrm{m}$ alt. Folhas levemente coriáceas; pecíolo 2-5,5 cm compr., glabro, pulvino espesso torcido no ápice; lâmina 6-10 ×3,5-5,8 cm, lanceolada, plana, base cuneada, margem inteira, levemente revoluta, ápice acuminado, ambas as faces glabras, face adaxial verde-escura, lustrosa, abaxial mais clara; nervuras principais 3 . Inflorescência estaminada paniculada; raque 3,5-11 cm compr., velutina. Flores masc. verdes; pedicelo 0,6-1,2 mm compr., velutino; sépalas membranáceas, margem inteira, ápice agudo, as externas $0,5-$ $0,6 \times$ ca. $0,2 \mathrm{~mm}$, lanceoladas, as internas $1-1,2 \times 0,8-0,9$ $\mathrm{mm}$, obovadas; pétalas ausentes; estames ca. $0,8 \mathrm{~mm}$ compr., filetes conatos na base, levemente torcidos no ápice, anteras extrorsas, rimosas. Inflorescência pistilada em racemo simples; raque 5-14 cm compr., velutina (Demuner 1133). Flores fem. não observadas. Drupa 25-28 × 13-20 mm, 11$15 \mathrm{~mm}$ de espessura, oblonga, imatura verde, madura amarela, glabra; endocarpo 23-26 × 11-18 mm, reticulado; se- 


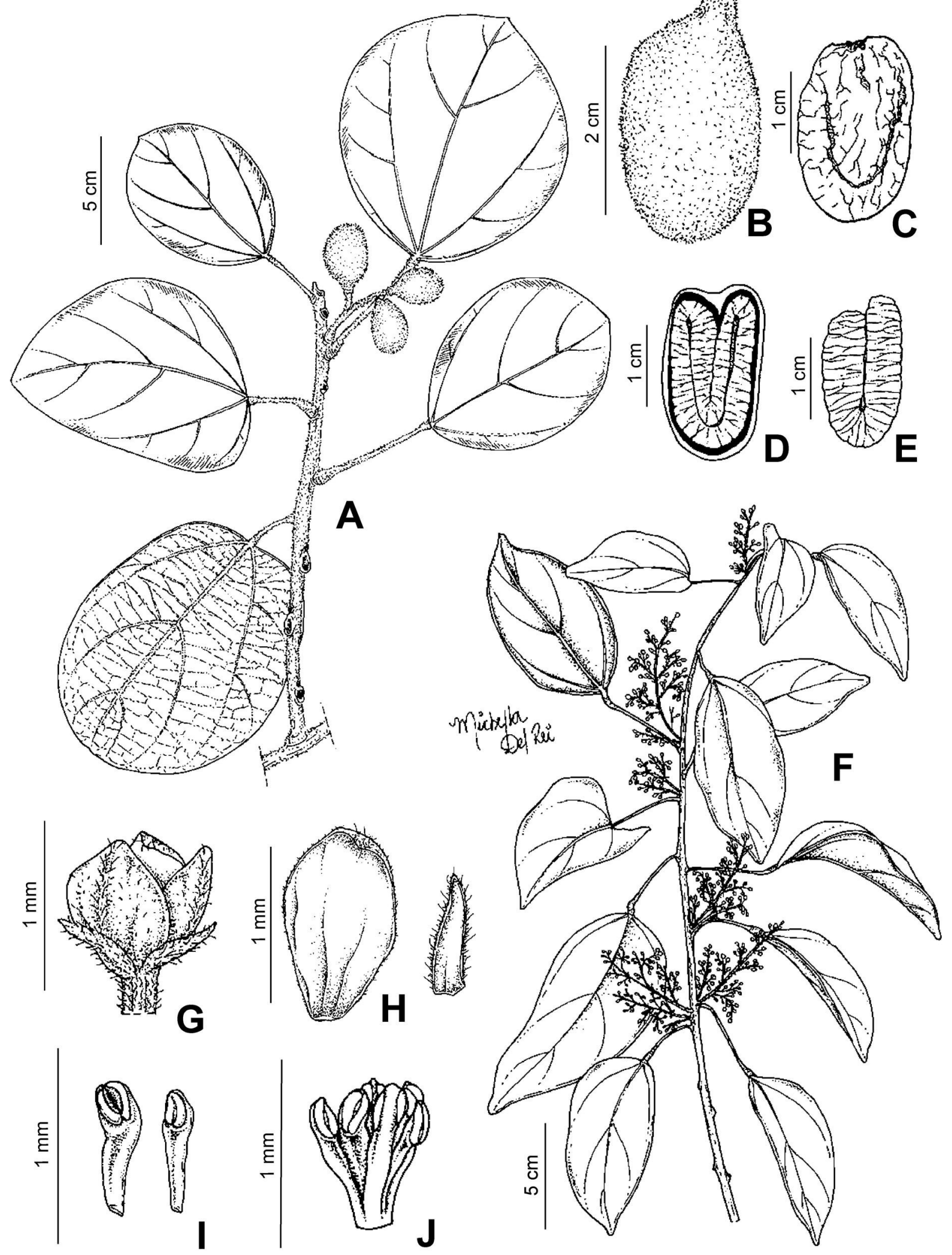

Figura 1. A-E. Abuta convexa: A- ramo com frutos; B- fruto, vista lateral; C- endocarpo; D- endocarpo, corte longitudinal; E- endosperma. F-J. Abuta selloana: F- ramo com inflorescências estaminadas; G- flor masc., vista lateral; H- sépala interna (esq.) e sépala externa (dir.), face adaxial; I- estames; J- androceu (A-E- Hatschbach 63017; F-J- Fiaschi 2595). 


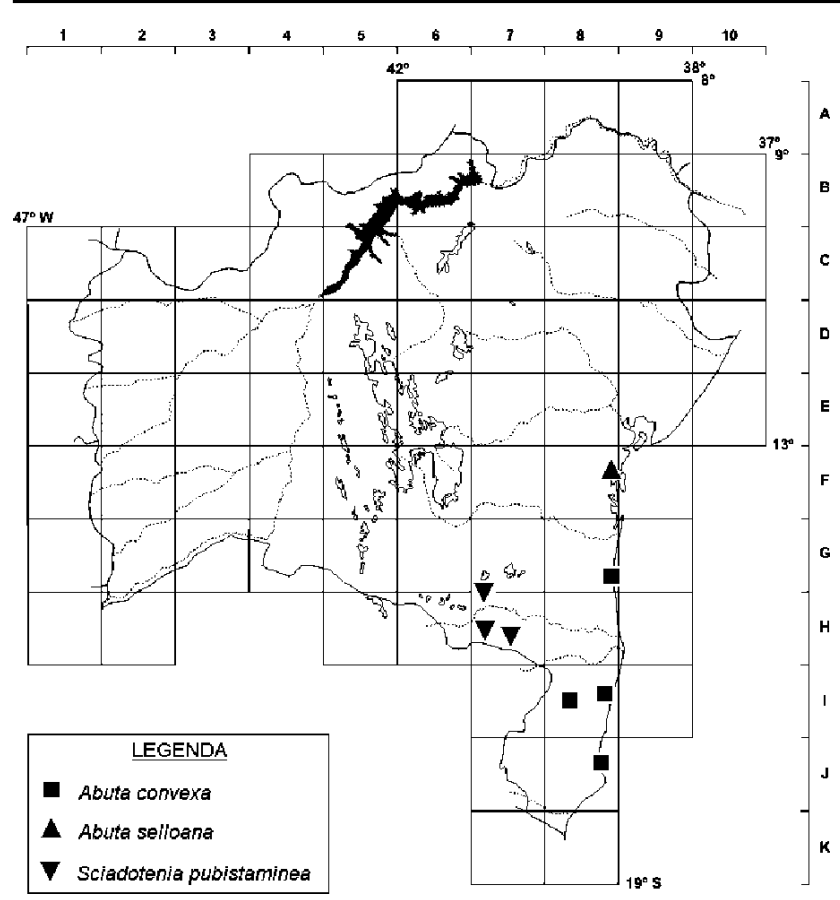

Figura 2. Distribuição geográfica de Abuta convexa, A. selloana e Sciadotenia pubistaminea no estado da Bahia.

mente ca. $22 \times 12 \mathrm{~mm}$ (Demuner 1133).

Espécie endêmica da Mata Atlântica brasileira, distribuída na Região Sudeste e em estados do Nordeste e Sul (Krukoff \& Moldenke 1938; Barneby \& Krukoff 1971; Krukoff \& Barneby 1974; Krukoff 1976, 1982; Barneby 1996; Braga 2010). F8: Floresta Ombrófila Densa. Coletada com flores em outubro.

Material examinado - Valença, $13^{\circ} 19^{\prime} 44^{\prime \prime} \mathrm{S}, 39^{\circ} 05^{\prime} 25^{\prime \prime} \mathrm{W}$, 30 out. 2004 (fl. masc.), P. Fiaschi et al. 2595 (CEPEC, SPF).

Material adicional examinado - ESPÍRITO SANTO: Santa Teresa, 14 jan. 2000 (fr.), V. Demuner \& R. Bausen 1133 (MBM, $\mathrm{RB})$.

Abuta selloana assemelha-se a Hyperbaena domingensis, podendo distinguir-se dela pelo pulvino espesso (vs. delgado) no ápice do pecíolo, flores masc. monoclamídeas (vs. diclamídeas), drupas oblongas (vs. obovoides) e sementes com endosperma ruminado (vs. sem endosperma). Também pode ser confundida com Borismene japurensis, que possui flores masc. diclamídeas, drupas elípticas a globosas e sementes com endosperma liso; em $A$. selloana as flores masc. são monoclamídeas, as drupas são oblongas e as sementes possuem endosperma ruminado. Este é o primeiro registro de $A$. selloana na Bahia.

\section{Anomospermum Miers}

Lianas. Folhas simples, pecíolo inserido na base; lâmina oblonga a elíptica; venação palmatinérvea, nervuras principais 3(-5). Inflorescência estaminada axilar ou supraaxilar, racemosa ou mais frequentemente com flor solitária; brácteas diminutas. Flores masc. diclamídeas, pediceladas; sépalas $6 \mathrm{em} 2$ séries, livres, as 3 externas menores, as 3 internas muito maiores; pétalas 6(-9), carnosas ou submembranáceas, involutas, abraçando completamente o estame; estames 6, filetes livres, eretos ou fortemente incurvados distalmente, anteras com deiscência rimosa ou transversal. Inflorescência pistilada axilar ou supra-axilar, racemosa, paniculada ou flor solitária; brácteas diminutas. Flores fem. com perianto semelhante ao das masc.; estaminódios 6, adnatos à base das pétalas; carpelos 3. Drupa obovoide a subglobosa, ligeiramente comprimida lateralmente, assimétrica; epicarpo coriáceo; mesocarpo mucilaginoso, delgado; endocarpo em forma de J, coriáceo, lenhoso ou crustáceo, externamente reticulado, côndilo lameliforme, não visível externamente; semente curvada, endosperma ruminado.

Anomospermum está posicionado na tribo Anomospermeae Miers (Diels 1910; nome corrigido em Forman 1982), e abrange 11 espécies distribuídas na América Central (Cuba, Nicarágua e Panamá) e na América do Sul (Bolívia, Brasil, Colômbia, Equador, Guiana, Guiana Francesa, Peru e Venezuela) (Barneby \& Krukoff 1971; Krukoff \& Barneby 1974; Krukoff 1982; Ortiz 2001). No Brasil, o gênero está representado por oito espécies e cinco subespécies, distribuídas nos estados da Região Norte e em estados do Centro-Oeste e Sudeste (Barneby \& Krukoff 1971; Krukoff 1976, 1982; Braga 2010). Anomospermum foi citado para a Bahia por Amorim et al. (2009) em um levantamento florístico, sendo aqui confirmada a ocorrência do gênero no estado.

\subsection{Anomospermum reticulatum (Mart.) Eichler, Flora 47:} 388. 1864.

Figuras 3 e 4.

Nome popular: bute (Jardim 1031).

Liana 5-15 m alt. Folhas subcoriáceas; pecíolo 3-7,5 cm compr., glabro, pulvino levemente torcido no ápice; lâmina 5,5-11(-13) ×3,5-5,5(-7) cm, oblonga a elíptica, base cuneada, margem inteira, ápice agudo, obtuso ou arredondado, glabra; nervuras principais 3. Inflorescência estaminada em racemo simples ou flor solitária; raque 1,2$3,5 \mathrm{~cm}$ compr., pubescente. Flores masc. amarelas; pedicelo 4-8 mm compr., glabro a incano; sépalas coriáceas, as externas $0,9-1 \times$ ca. $0,9 \mathrm{~mm}$, ovadas, pubescentes, ápice acuminado, as internas 4-5,5 × 3,5-4,2 mm, côncavas, largo-elípticas a elípticas, glabras a levemente pilosas no centro; 6 pétalas, 2,6-3,2 $\times 2,1-2,6 \mathrm{~mm}$, obdeltoides, carnosas, levemente pilosas no centro, margem inteira, ápice obtuso a arredondado; estames 2,1-2,9 mm compr., filetes incurvados, anteras introrsas, rimosas. Inflorescência pistilada semelhante à masc.; raque 4-12 cm compr., lenticelada, glabra. Flores fem. amarelas; pedicelo 5-20 mm compr., glabro a incano; sépalas como nas flores masc.; pétalas 6, obdeltoides, carnosas, glabras, margem inteira, ápice arredondado a truncado, as externas 1,7-1,8 $\times 1,1 \mathrm{~mm}$, as internas $2 \times 1,3-1,4$ $\mathrm{mm}$; estaminódios 1,5-2 mm compr., incurvados, glabros; carpelos 1,8-2,5 × 1,1-1,5 mm, estigma séssil, estreitoobtriangular, dilatado. Drupa 26-35 × 20-29 mm, 15-28 

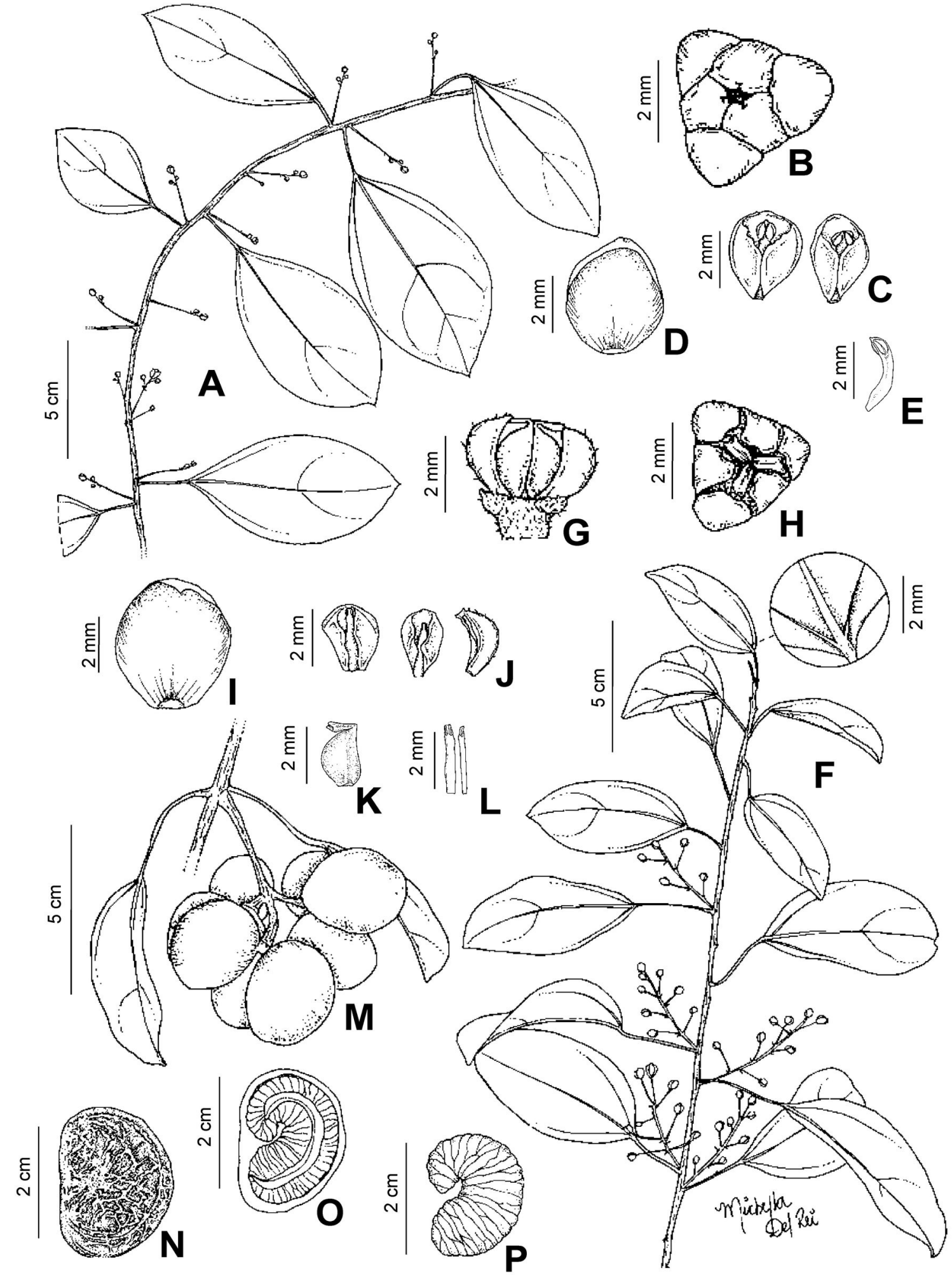

Figura 3. Anomospermum reticulatum: A- ramo com inflorescências estaminadas; B- flor masc., vista adaxial (sépalas removidas); C- sépalas, face adaxial; D- pétala externa e interna (dir.), face adaxial; E- estame, vista lateral; F- ramo com inflorescências pistiladas; G- flor fem., vista lateral, H- flor fem., vista adaxial (sépalas removidas); I- sépala, vista adaxial; J- pétalas, vista adaxial e lateral (dir.); K- carpelo, vista lateral; L- estaminódios, vista adaxial (esq.) e lateral (dir.); M- ramo com frutos, N- endocarpo, vista lateral; O- endocarpo, corte longitudinal; P- endosperma (A-E- Souza 33; F-LFiaschi 2880; M-P- Del-Rei 43). 
M. D. R. Teixeira \& A. M. A. Amorim - Menispermaceae da Bahia

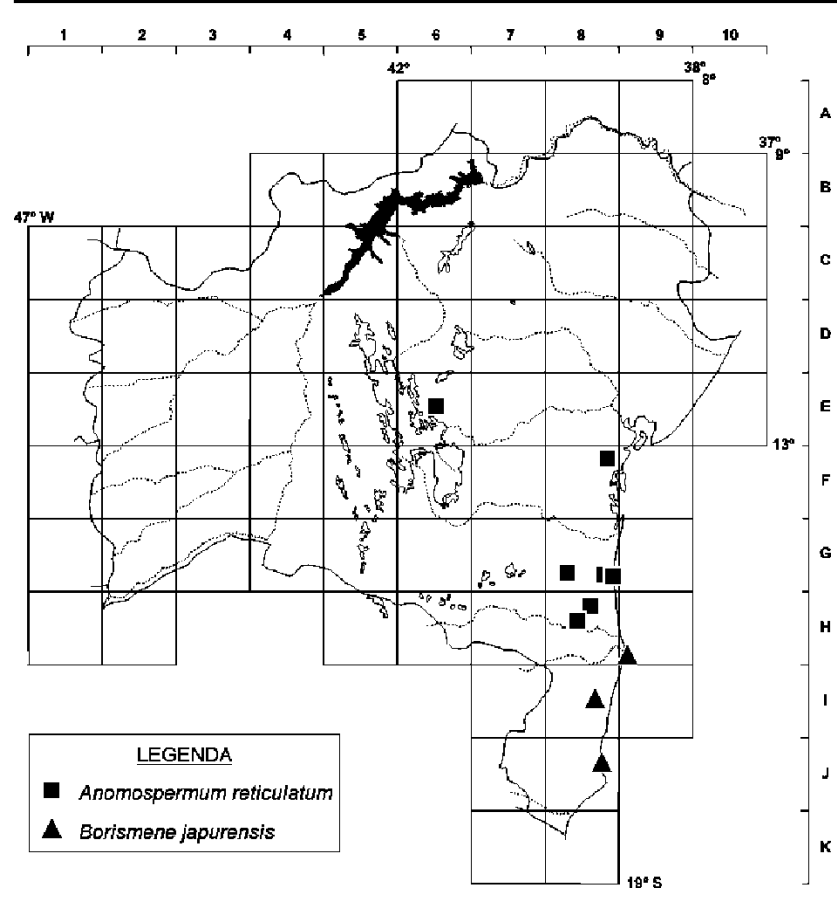

Figura 4. Distribuição geográfica de Anomospermum reticulatum e Borismene japurensis no estado da Bahia.

mm de espessura, subglobosa, madura amarelo escuro com máculas amarelo-alaranjadas, glabra; endocarpo 24-30×18$25 \mathrm{~mm}$; semente ca. $22 \times 13-15 \mathrm{~mm}$.

Ocorre na América Central (Costa Rica, Nicarágua e Panamá) e América do Sul (Bolívia, Brasil, Colômbia, Equador, Peru e Venezuela) (Barneby \& Krukoff 1971; Krukoff 1976, 1982; Ortiz 2001). No Brasil, está distribuída em estados das Regiões Norte, Nordeste, Centro-Oeste e Sudeste (Braga 2010). E6, F8, G8, H8: Floresta Estacional Semidecidual e Floresta Ombrófila Densa Submontana e Montana. Coletada com flores masc. em fevereiro, flores fem. em fevereiro e março, e com frutos de janeiro a setembro.

Material selecionado -Almadina, 1444'06'S, 3941'46”'W, 28 fev. 1997 (fl. fem. e fr.), J.G. Jardim et al. 1031 (CEPEC, HUESC); Amargosa, 13ำ's, 3909'W, 12 maio 2007 (fr.), J.L. Paixão et al. 1264 (HUEFS); Arataca, 15'11'22'S, 39²3'07'W, 7 fev. 2009 (fr.), M. Del-Rei et al. 43 (CEPEC); Barro Preto, 1446'13"S, 39¹2'10"W, 4 maio 2005 (fr.), A.M.A. Amorim et al. 4856 (CEPEC); Camacan, 15²3'30”'S, 39³3'55'W, 850 m, 18 mar. 2005 (fl. fem.), P. Fiaschi et al. 2880 (CEPEC, SPF); Ilhéus, 1446'55'S, 3904'09'W, 16 jan. 1995 (est.), A.M. Carvalho et al. 5774 (CEPEC); Palmeiras, $12^{\circ} 27^{\prime}$ S, 41 ${ }^{\circ} 28^{\prime} \mathrm{W}, 25$ fev. 2005 (fl. masc.), A.E.A. Souza et al. 33 (HUEFS).

Anomospermum reticulatum distingue-se de Orthomene schomburgkii principalmente pelas drupas subglobosas com endocarpo em forma de $\mathrm{J}$ e sementes recurvada, enquanto $O$. schomburgkii possui drupas elipsoides com endocarpo e sementes lineares. A espécie também pode ser reconhecida pelas folhas com nervuras principais laterais proeminentes, pecíolo $=3 \mathrm{~cm}$ compr., flores masc . com pétalas abraçando os estames e flores fem. com pétalas cobrindo completamente o ovário, expondo apenas os estigmas, enquanto $O$. schomburgkii apresenta folhas com nervuras principais laterais não proeminentes, pecíolo $<3 \mathrm{~cm}$ compr., flores masc. com pétalas ligeiramente menores que os estames e flores fem. com pétalas cobrindo apenas parcialmente o ovário, expondo o $1 / 3$ superior e os estigmas.

\section{Borismene Barneby}

Lianas. Folhas simples, pecíolo inserido na base; pulvino no ápice e na base do pecíolo, torcido na base; lâmina ovado-lanceolada, membranácea, coriácea ou subcoriácea, concolor; venação palmatinérvea, nervuras principais 3 . Inflorescência estaminada axilar a supra-axilar, paniculada; brácteas diminutas. Flor masc. diclamídea; sépalas 9, livres, geralmente em 3 séries, sendo 3 externas pequenas e 6 internas muito maiores, prefloração valvar a imbricada; pétalas 6, livres, membranáceas, glabras, levemente involutas; estames 6, glabros, livres, eretos ou incurvados na antese, anteras introrsas, deiscência transversal. Inflorescência pistilada axilar, racemosa a paniculada; brácteas diminutas. Flor fem. com perianto semelhante ao das masc.; carpelos 3. Drupa obovoide a globosa; epicarpo coriáceo, glabro; mesocarpo mucilaginoso, delgado; endocarpo linear, cartáceo, côndilo visível externamente, com intrusão longitudinal; semente linear, endosperma liso.

Borismene está posicionado na tribo Fibraureae Diels (Diels 1910). O gênero é monoespecífico e ocorre no Brasil, Colômbia, Peru e Venezuela (Kessler 1993; Barneby 1996; Funk et al. 2007).

\subsection{Borismene japurensis (Mart.) Barneby, Mem. New} York Bot. Gard. 22(4): 145. 1972.

Figuras 4 e 5.

Liana ca. $35 \mathrm{~m}$ alt. Folhas levemente coriáceas; pecíolo 1,8-4,5 cm compr., glabro; lâmina 7-10,5 × 3,4-5,1 cm, ovado-lanceolada, base arredondada, margem inteira, levemente revoluta, ápice acuminado, ambas as faces glabras, face adaxial brilhante; nervuras principais unidas na base até ca. (1-)5 mm compr. Inflorescência estaminada com raque 4-37 cm compr., glabra. Flores masc. verdes; pedicelo ca. 2,5 mm compr., glabro; sépalas glabras, membranáceas, as externas $0,6-0,8 \times 0,4-0,6 \mathrm{~mm}$, obovadas a oblanceoladas, margem inteira, ápice acuminado, as internas 2,2-2,5 × 1,1$1,9 \mathrm{~mm}$, obovadas, involutas, margem levemente crenulada, ápice arredondado; pétalas 1,2-1,5×1,1-1,3 mm, obovadas a deltoides, margem levemente crenulada, ápice levemente truncado; estames ca. 0,9 mm compr., filetes adnatos à base das pétalas. Inflorescência pistilada racemo composto; raque 13-38 cm compr., glabro. Flores fem. não observadas. Drupa 20-25 × 13-15 mm, 13-14 mm de espessura, madura vermelha; pedicelo ca. $1 \mathrm{~cm}$ compr., glabro; endocarpo 14-15 × 8-10 mm, superfície lisa; semente ca. $13 \times 8 \mathrm{~mm}$.

Ocorre em estados das Regiões Norte, Nordeste e Sudeste (Braga 2010). H9, I8, J8: Floresta Ombrófila Densa Submontana. Coletada com flores masc. em novembro e com 


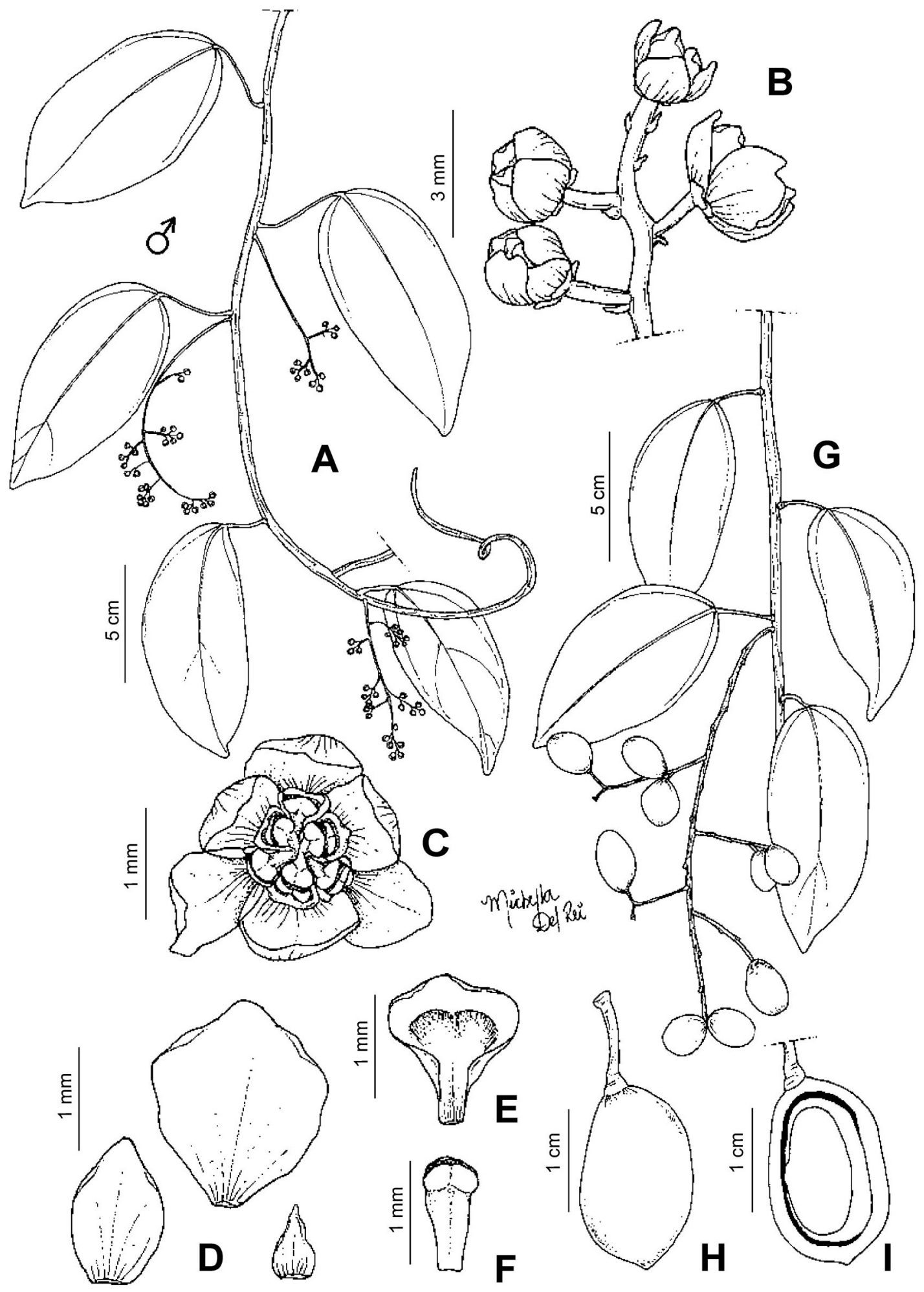

Figura 5. Borismene japurensis: A- ramo com inflorescências estaminadas; B- detalhe de um ramo da inflorescência estaminada; C- flor masc., vista adaxial; D- sépalas, vários verticilos, vista adaxial; E- pétala, vista adaxial; F- estame, vista adaxial; G- ramo com frutos; H- fruto, vista lateral; I- fruto, corte longitudinal (A-F- Santos 4345; G-I- Mattos-Silva 568). 
frutos em abril e julho.

Material examinado - Belmonte, 29 nov. 1987 (fl. masc.), T.S. Santos 4345 (CEPEC); Porto Seguro, 16²7’45”S, 39¹9’31'W, 7 abr. 1994 (fr.), J.G. Jardim et al. 390 (CEPEC); Prado, 5 jul. 1979 (fr.), L.A. Mattos-Silva et al. 568 (CEPEC, RB).

Como discutido anteriormente, Borismene japurensis distingue-se das demais espécies de Menispermaceae na Bahia por apresentar flores masc. diclamídeas, com nove sépalas, drupas elipsoides a globosas e sementes com endosperma liso (ver comentários em A. selloana).

\section{Chondrodendron Ruiz \& Pav.}

Lianas. Folhas simples, peltadas ou não; pecioladas, pulvino no ápice e na base, levemente torcido no ápice; lâmina ovada a cordiforme, discolor; venação palmatinérvea, nervuras principais 5-7. Inflorescência estaminada cauliflora ou axilar em ramo jovem, paniculada, às vezes racemosa, com várias inflorescências saindo de um mesmo nó; brácteas diminutas. Flores masc. diclamídeas; sépalas 12 ou mais em 4 a 6 séries, prefloração valvar a imbricada, as mais externas 3 , diminutas, as internas 6-12, maiores, livres, membranáceas, face abaxial velutina; pétalas 6 , menores que as sépalas internas, glabras, subcarnosas; estames (3-)6, livres, raro conatos, anteras introrsas, deiscência rimosa, raro transversal. Inflorescência pistilada cauliflora, racemosa, geralmente menos ramificada e com menos flores que a estaminada; brácteas diminutas. Flores fem. com perianto semelhante ao das masc.; estaminódios ausentes; carpelos 6. Drupa oblongo-obovoide, imatura pubérula, madura glabra, com estípite até $1 / 4$ do compr. do fruto; epicarpo coriáceo; mesocarpo delgado; endocarpo em forma de U invertido, cartáceo, superfície fibrosa, côndilo não visível externamente, lameliforme; semente curvada, endosperma ausente.

Chondrodendron pertence à tribo Tiliacoreae Miers (Diels 1910; nome corrigido em Forman 1982), sendo representado por 8 a 10 espécies, com distribuição em alguns países da América Central (Panamá) e América do Sul (Bolívia, Brasil, Colômbia, Equador e Peru) (Macbride 1938; Rhodes 1962; Barneby \& Krukoff 1971; Krukoff \& Barneby 1974; Krukoff 1976, 1982; Kessler 1993). No Brasil, o gênero está representado por três espécies que se distribuem na Região Sudeste e em estados do Norte e Nordeste (Braga 2010). Na Bahia, ocorrem duas espécies, ambas com distribuição predominantemente em Floresta Atlântica.

\section{Chave para as espécies}

1. Planta estaminada.

2. Lâmina foliar com margem inteira; flor masc. com 18 sépalas e pétalas unguiculadas, estames 3 , em sinândrio 4.1. C. microphyllum

2'. Lâmina foliar com margem inteira a levemente enulada; flor masc. com 12-15 sépalas e pétalas truladas, estames 6, livres 4.2. C. platiphyllum

1'. Planta pistilada, com fruto.
3. Flor fem. com carpelos 1-1,1 mm compr.; drupas com estípite 1-3 mm compr. ...4.1. C. microphyllum

3'. Flor fem. com carpelos ca. 1,5 mm compr.; drupas com estípite 5-10 mm compr.....4.2. C. platiphyllum

\subsection{Chondrodendron microphyllum (Eichler) Moldenke,} Brittonia 3(1): 11. 1938.

Figuras 6 e 7.

Nome popular: buti ou bute (Mori 12753).

Lianas ca. $4 \mathrm{~m}$ alt. Folhas membranáceas; pecíolo 2,5$8 \mathrm{~cm}$ compr., pubescente a velutino; lâmina 5-20 × 7-16 $\mathrm{cm}$, ovada a levemente cordiforme, base arredondada a levemente cuneada, cordada, raro truncada, margem inteira, ápice agudo a cuspidado, face adaxial verde brilhante, glabra, abaxial alva a acinzentada, pubescente ou velutina; nervuras principais 5-7. Inflorescência estaminada paniculada; raque $4-10 \mathrm{~cm}$ compr., velutina. Flores masc. verde-amareladas ou creme; pedicelo 1-2 mm compr., velutino; sépalas 18 , ápice agudo, as 12 externas $0,5-1,9 \times 0,5-1,1 \mathrm{~mm}$, ovadas a elípticas, margem inteira, as 6 internas 2,2-2,6 × 1,2-1,4 $\mathrm{mm}$, elípticas, margem inteira a levemente crenulada, revolutas; pétalas ca. $1 \times 0,4 \mathrm{~mm}$, unguiculadas, conatas na base, margem inteira, ápice agudo; estames 3, em sinândrio, 1,2-1,6 mm compr., anteras introrsas, rimosas. Inflorescência pistilada em racemo composto; raque 5,5-9 cm compr., glabra a levemente pubescente. Flores fem. alvas; pedicelo 5-13 mm compr., pubescente a glabro; sépalas semelhantes às das flores masc.; pétalas ca. $0,7 \times 0,4 \mathrm{~mm}$, unguiculadas, margem inteira, ápice agudo; carpelos 1-1,1 $\times 0,4-0,5 \mathrm{~mm}$. Drupa $10-16 \times 8-12 \mathrm{~mm}, 8-11 \mathrm{~mm}$ de espessura, obovoide, madura enegrecida, com estípite $1-3 \times$ 14 1,5-2 mm; epicarpo glabro; endocarpo 8-18 × 6-9 mm, obovoide, reticulado; semente 7-16 × 6-7 mm.

Endêmica do Brasil, nos estados da Bahia e do Rio Grande do Norte (Barneby \& Krukoff 1971; Krukoff 1976, 1982; Barneby 1996; Braga 2010). E8, F7, F8, G7, G8, H7, H8, I8: Floresta Estacional Semidecidual e Floresta Ombrófila Densa Submontana. Coletada com flores masc. de janeiro a julho e de outubro a dezembro, flores fem. em março e setembro, e frutos de janeiro a outubro.

Material selecionado-Almadina, 1442'21'"S, 39³6'12' W, 17 dez. 2006 (fl. masc.), R.A.X. Borges et al. 451 (CEPEC, NY n.v., RB, SP); Amargosa, 13ำ'S, 3909'W, 29 abr. 2007 (fr.), J.L. Paixão et al. 1172 (HUEFS); Arataca, 15¹0'25”'S, 39²0'30'W, 15 maio 2005 (fl. masc.), A.M.A. Amorim et al. 4999 (CEPEC); Belmonte, $16^{\circ} 00^{\prime} \mathrm{S}, 3^{\circ} 9^{\circ} 03^{\prime} \mathrm{W}, 24$ mar. 1974 (fl. masc.), R.M. Harley 17354 (CEPEC, RB); Boa Nova, 18 maio 2001 (fl. masc.), W.W. Thomas \& S. Sant'Ana 12476 (CEPEC, NY n.v.); Camacan, 20. fev. 1970 (fl. masc.), J.A. Jesus 524 (CEPEC); Camamu, 1400'S, 39²13'W, 15 jun. 1979 (fl. masc.), L.A. MattosSilva et al. 504 (CEPEC); Ibicaraí, 2 mar. 1978 (fl. masc.), S. Mori et al. 9366 (CEPEC, RB); Ilhéus, 27 nov. 1987 (fl. masc.), P.J.M. Maas et al. 7064 (CEPEC). Itacaré, 16 fev. 1978 (fl. masc.), T.S. Santos \& L.A.M. Silva 3187 (CEPEC, RB); Itagibá, $14^{\circ} 10^{\prime} 35^{\prime}$ 'S, 3943'55”'W, 22 mar. 2008 (fl. masc.), C.E. Ramos et al. 97 (ALCB); Itambé, 3 mar. 1978 (fl. masc.), S.A. Mori et al. 

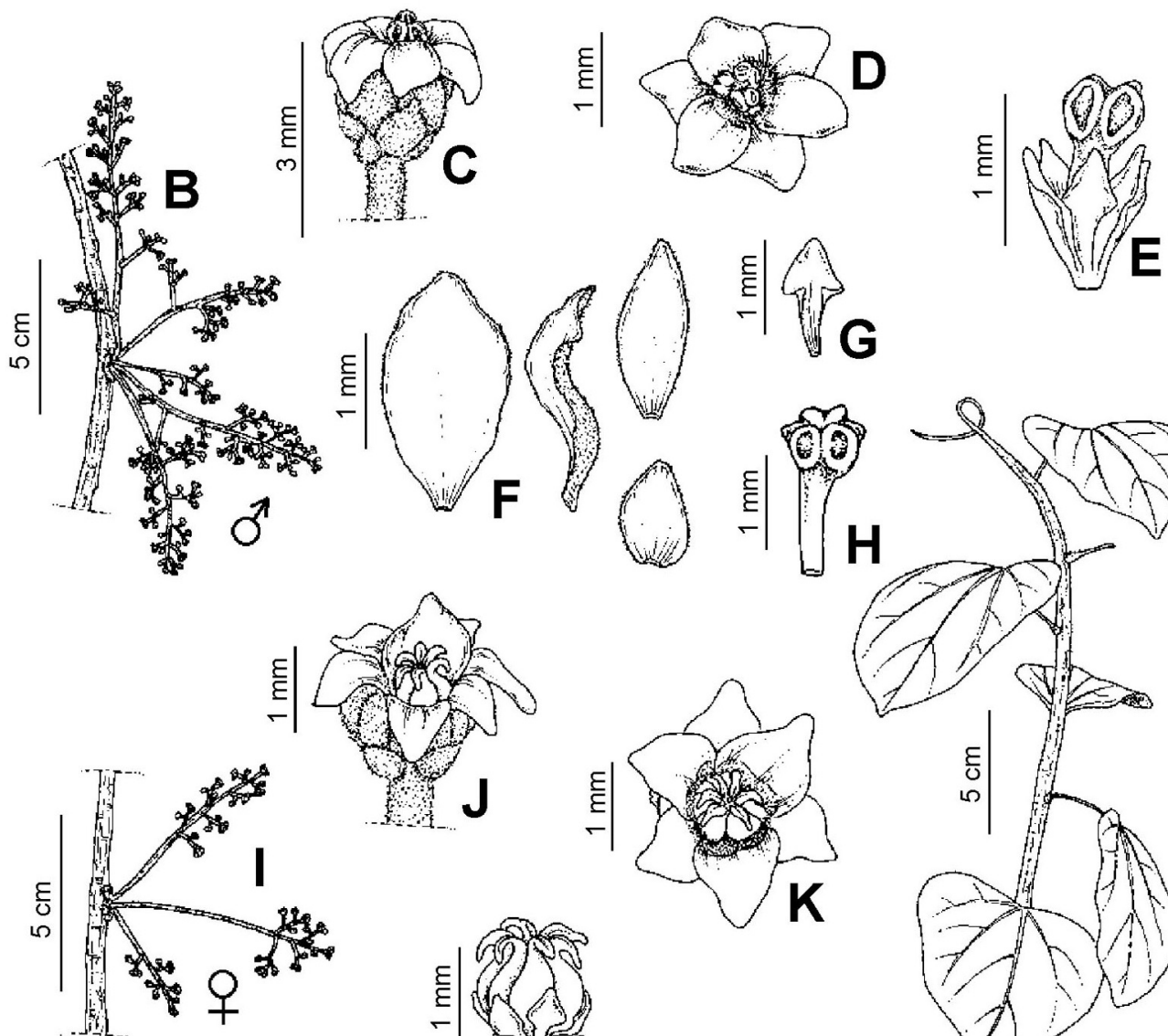

$\stackrel{\varepsilon}{-} \vec{r}$

$\mathbf{G}$
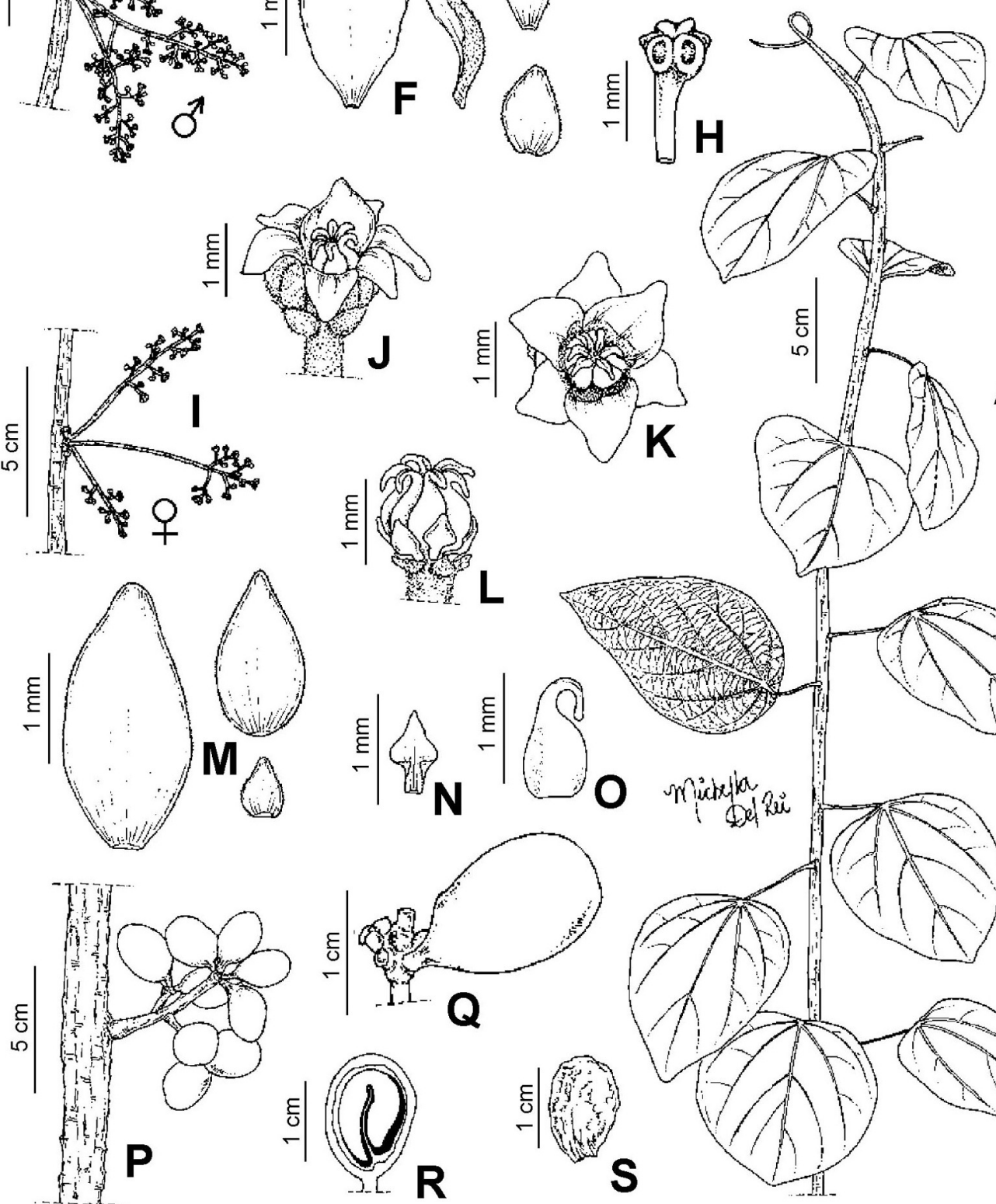

0 mickitar pus

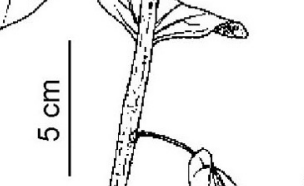


M. D. R. Teixeira \& A. M. A. Amorim - Menispermaceae da Bahia

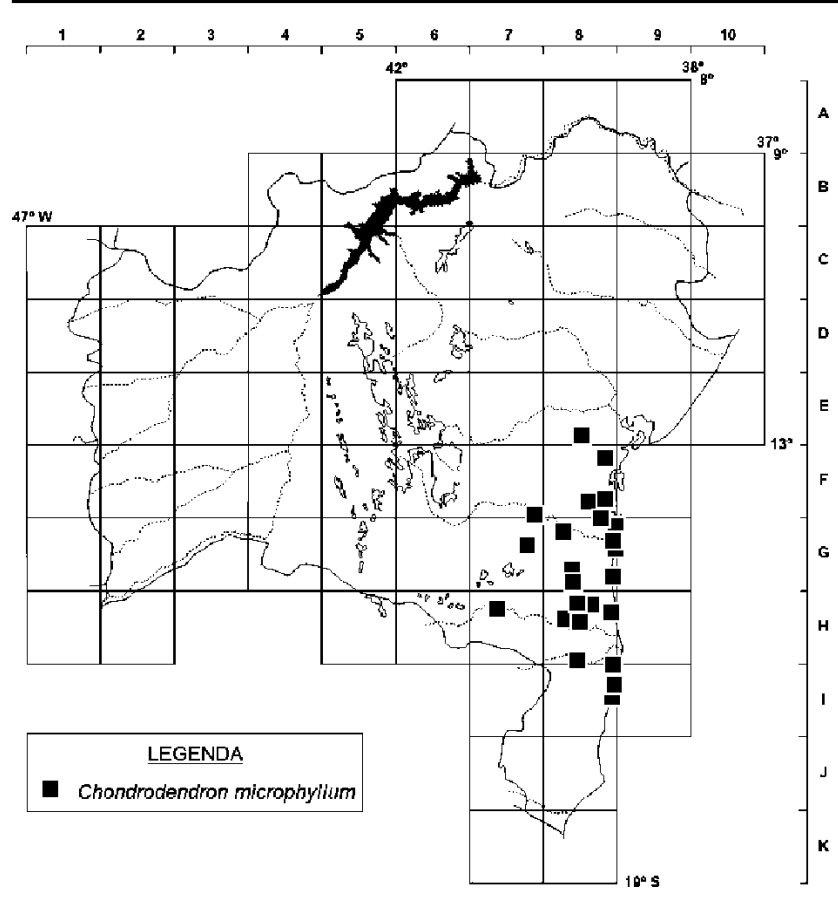

Figura 7. Distribuição geográfica de Chondrodendron microphyllum no estado da Bahia.

9384 (CEPEC); Itapebi, 16 nov. 1967 (fl. masc.), R.S. Pinheiro \& T.S. Santos 446 (CEPEC); Ituberá, 27 out. 2006 (fr.), R.M. Valadão 460 (ALCB); Jequié, 1356'41,4”S, 4006’33,9”W, 29 ago. 2003 (fr.), G.E.L. Macedo et al. 202 (HUESB, PEUFR n.v., RB); Jussari, 1509'29”'S, 39³1'43”'W, 19 set. 2002 (fl. fem. e fr.), P. Fiaschi et al. 1090 (CEPEC); Maraú, 5 fev. 1979 (fl. masc.), S.A. Mori et al. 11341 (CEPEC); Pau Brasil, 15²2'51'’S, 3942’01'”, 15 abr. 1997 (fl. masc.), W.W. Thomas et al. 11512 (CEPEC); Piraí do Norte, 4 fev. 2002 (fl. masc.), P. Fiaschi et al. 987 (SPF); Porto Seguro, 26 nov. 1970 (fl. masc.), L.E. Mello-Filho et al. 2935 (CEPEC); Santa Cruz Cabrália, 28 nov. 1978 (fl. masc.), A. Eupunino 397 (CEPEC); Santa Terezinha, 12 ${ }^{\circ}$ ' $11^{\prime \prime}$, 39॰28’37’'W, 1 abr. 2004 (fl. masc.), M.L.C. Neves 39 (HUEFS); Una, 13 nov. 1969 (fl. masc.), T.S. Santos 498 (CEPEC, RB); Uruçuca, fazenda Dendhevea, 4 set. 1974 (fl. masc.), T.S. Santos 2767 (CEPEC, RB).

Chondrodendron microphyllum é muitas vezes confundida com $C$. platiphyllum, sendo que as duas espécies podem ocorrer simpatricamente. No entanto, distingue-se de C. platiphyllum principalmente por apresentar três estames conatos em sinândrio, enquanto, em $C$. platiphyllum, há 6 estames livres. Na ausência de flores estaminadas, $C$. microphyllum pode ser reconhecida pelas folhas com margem inteira e pelos frutos com estípite 1-3 mm compr. Em C. platiphyllum, as folhas possuem margem levemente crenulada e os frutos possuem estípite 5-10 mm compr.

\subsection{Chondrodendron platiphyllum (A.St.-Hil.) Miers,} Ann. Mag. Nat. Hist. ser. 3, 19 (122): 192. 1867.

Figuras 8A-J e 9.

Nome popular: buti (Mori 10840).

Liana 4-20 $\mathrm{m}$ alt. Folhas membranáceas a levemente coriáceas; pecíolo 9-13 cm compr., pubescente; lâmina 5,5-
$21 \times 12-15 \mathrm{~cm}$, ovada a largo-ovada, levemente cordiforme, base levemente truncada a subcordada, margem inteira a levemente crenulada, ápice agudo, face adaxial flocosa quando jovem, adulta com face adaxial verde-escura, brilhante, glabra, face abaxial alva a cinza, pálida, geralmente velutina, raro glabra; nervuras principais 5. Inflorescência estaminada paniculada; raque (5-)12-38 cm compr., velutina. Flor masc. verde-clara, alva ou creme; pedicelo 1-2 mm compr., velutino; sépalas $12-15$, livres, pilosas na face abaxial, margem inteira, as externas $0,9-1,5 \times 0,5-0,8$ $\mathrm{mm}$, ovadas, ápice agudo a arredondado, as internas 2,22,6 × 1,2-1,4 mm, elípticas, revolutas, ápice agudo; pétalas 1,1-1,5 × ca. $0,5 \mathrm{~mm}$, truladas, livres, glabras, margem inteira, ápice agudo; estames 6, livres, 1,4-1,6 mm compr., conectivo apiculado, anteras rimosas. Inflorescência pistilada em racemo composto; raque (4-)5-25 cm compr., velutina, glabra quando com fruto. Flores fem. com perianto semelhante ao das masc.; pedicelo 5-15 mm compr. no fruto; carpelos ca. 1,5 $\times 0,5 \mathrm{~mm}$, glabros (Diels 1910). Drupa 12-27 $\times 7-17 \mathrm{~mm}$, obovoide, madura vinácea, com estípite 5-10 × 2-4 mm; epicarpo glabro; endocarpo 10-23 × 5-14 $\mathrm{mm}$, elipsoide; semente 9-22 × 4-13 mm.

Endêmica do Brasil, onde ocorre em estados da Região Nordeste e em todos os estados do Sudeste (Krukoff \& Barneby 1974; Krukoff 1976, 1982; Barneby 1996; Braga 2010). D/E10, E9, E10, F8, G8, H8, I8, J8: Floresta Ombrófila Densa Submontana e Montana. Coletada com flores masc. em janeiro, fevereiro, maio, setembro, novembro e dezembro, e com frutos de fevereiro a junho, em agosto e novembro.

Material selecionado - Almadina, 14\%44'11''S, 3941'57' W, 4 abr. 1997 (fr.), W.W. Thomas et al. 11461 (MBM, NY n.v.); Arataca, 15¹0'25'S, 39²0'30”'W, 12 fev. 2005 (fl. masc.), J.G. Jardim et al. 4363 (CEPEC, SPF); Camacan, 15²3'30"S, 39³3'55'W, 16-20 jun. 2009 (fr.), M. Del-Rei et al. 50 (CEPEC); Conde, 1202'24”'S, 3742'38'W, 29 nov. 1994 (fr.), E. Rosas et al. 55 (HRB, RB); Eunápolis, 16²2'S, 39³4'W, 8 fev. 2003 (est.), B.A. Anjos et al. 18 (ALCB); Itabela, 13 ago. 1995 (fr.), G. Hatschbach et al. 63069 (MBM); Itacaré, 14¹8'S, 3903'W, 29 mar. 1974 (fr.), R.M. Harley 17476 (CEPEC); Jaguaquara, 3 abr. 2010 (est.), M. Del-Rei \& A. Teixeira 104 (HUEFS); Porto Seguro, 15 maio 1971 (fl. masc.), T.S. Santos 1646 (CEPEC); Prado, $17^{\circ} 11^{\prime}$ S, $39^{\circ} 20^{\prime}$ W, 11 jun. 2009 (fr.), F.B. Matos et al. 1686 (CEPEC); Santa Cruz Cabrália, 16²16'S, 3901'W, 20 jun. 1999 (fr.), S.S. Lima et al. 12 (ALCB); São Sebastião do Passé, 27 set. 2009 (fl. masc.), M. Del-Rei et al. 61 (HUEFS); Ubaíra, 1309'50"'S, 39³9'30”'W, 27 maio 2007 (fr.), J.L. Paixão et al. 1282 (HUEFS); Uruçuca, 14²8'09”S, 3904'24”W, 5 abr. 2004 (fr.), A.M. Amorim et al. 3931 (CEPEC).

Como discutido anteriormente, Chondrodendron platiphyllum assemelha-se a $C$. microphyllum, podendo ser reconhecida principalmente pelas flores masc. com seis estames livres, folhas com a margem levemente crenulada e drupa com estípite 5-10 mm compr. (ver comentários em $C$. microphyllum).

Sitientibus série Ciências Biológicas 12(2): 207-243. 2012. 


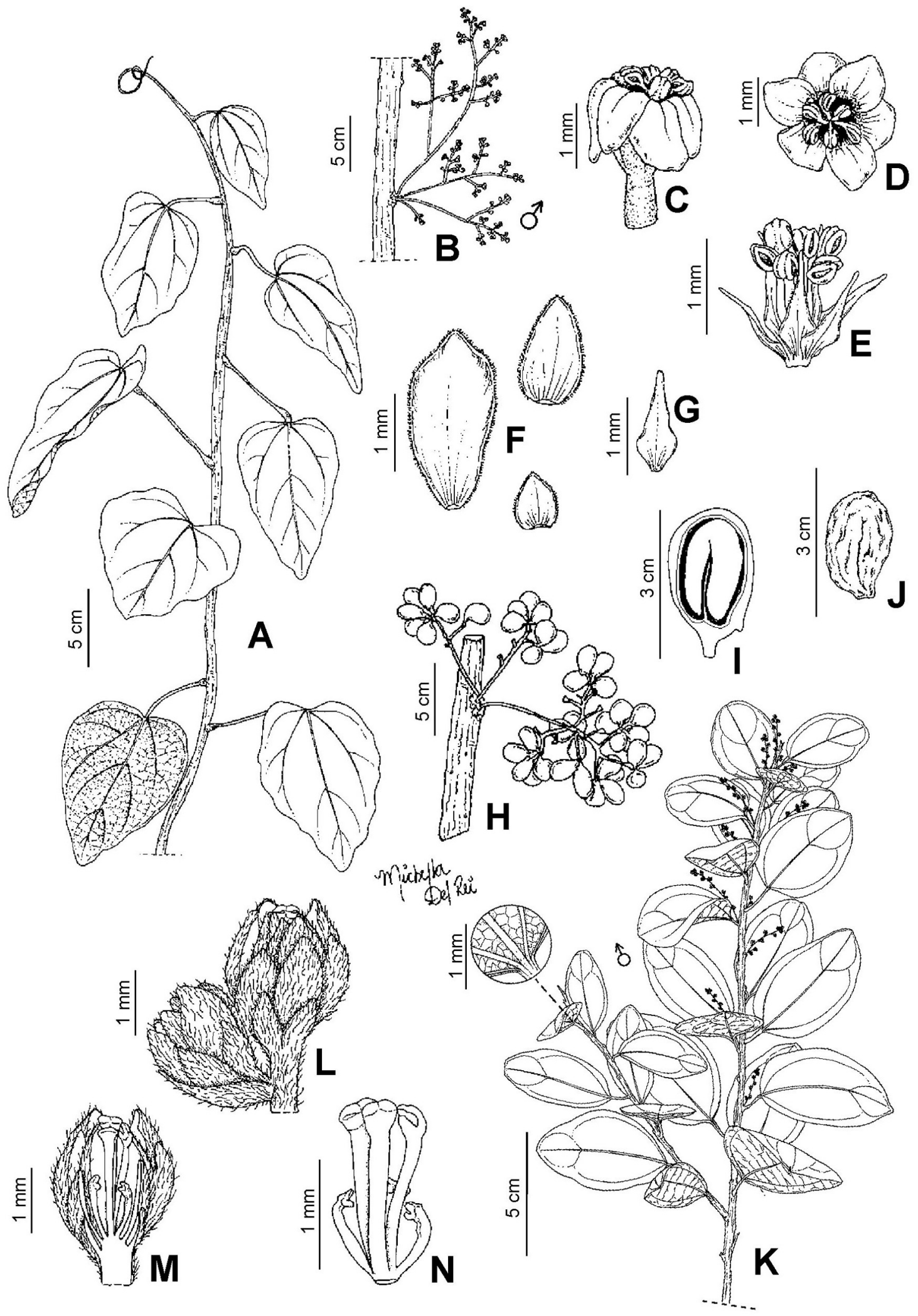

Figura 8. A-J. Chondrodendron platiphyllum: A- ramo estéril; B- ramo com inflorescências estaminadas; C- flor masc., vista lateral; D- flor masc., vista adaxial; E- pétalas e androceu; F- sépalas, vários verticilos, vista adaxial; G- pétala, vista adaxial; H- ramo com infrutescências; I- fruto, corte longitudinal; J- endocarpo, vista lateral. K-N. Sciadotenia campestris: K- ramo com inflorescências estaminadas; L- detalhe de um ramo da inflorescência; M- flor masc., corte longitudinal; N- androceu (A, H-J- Del-Rei 50; B-G- Del-Rei 61; K-N- Hatschbach 50530). 
M. D. R. Teixeira \& A. M. A. Amorim - Menispermaceae da Bahia

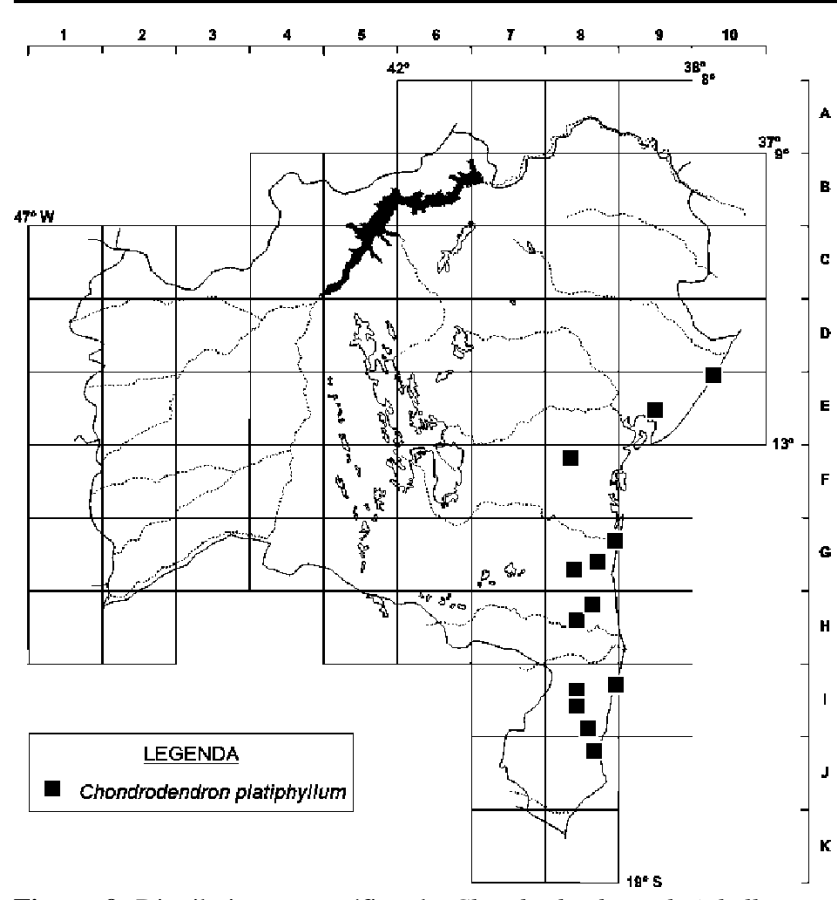

Figura 9. Distribuição geográfica de Chondrodendron platiphyllum no estado da Bahia.

\section{Cissampelos L.}

Lianas, raro ervas eretas. Folhas simples; peltadas ou não; lâmina membranácea, cartácea ou subcoriácea; venação palmatinérvea, nervuras principais 5-12. Inflorescência estaminada axilar ou cauliflora, paniculada ou tirsiforme; brácteas cordadas a lanceoladas. Flores masc. actinomorfas, diclamídeas, geralmente creme-esverdeadas; sépalas 4(5), valvares, membranáceas, levemente conatas na base, geralmente pilosas na face abaxial; corola campanulada a tubular, às vezes rotada, pétalas 4 , conatas, membranáceas, glabras; estames 4-9, conatos em sinândrio, glabros, anteras extrorsas, deiscência transversal. Inflorescência pistilada axilar ou cauliflora, geralmente racemosa, fasciculada; brácteas cordadas a lanceoladas. Flores fem. zigomorfas, diclamídeas, numerosas; sépala 1, geralmente pilosa na face abaxial; pétala 1 , menor que a sépala, geralmente glabra; estaminódios ausentes; carpelo 1, estilete curto ou ausente, estigma 3-5lobado. Drupa subglobosa a obovoide; epicarpo membranáceo, delgado, piloso, às vezes glabro; mesocarpo mucilaginoso; endocarpo hipocrepiforme, crustáceo, com cristas laterais e dorsoventrais, geralmente espiciformes, côndilo parcialmente visível externamente, com intrusão lateral, geralmente atenuado; semente curva, endosperma liso.

Cissampelos está posicionado na tribo Menispermeae (Diels 1910; nome corrigido em Forman 1982), sendo o único gênero da tribo representado no Brasil. Cissampelos está representado por 19 a 25 espécies com distribuição nas Américas, África, Ásia e Austrália (Rhodes 1962, 1975; Ortiz 2001). No Brasil, o gênero está representado por 10 espécies distribuídas em estados das Região Norte e Nordeste e em todos os estados das Regiões Centro-Oeste, Sudeste e Sul (Rhodes 1975; Braga 2010). Na Bahia, foram encontradas seis espécies, uma delas não identificada.

\section{Chave para as espécies}

1. Planta estaminada.

2. Erva ereta $<80 \mathrm{~cm}$ alt.

2'. Liana $>1 \mathrm{~m}$ alt.

3. Folhas não peltadas; flores masc. com brácteas lanceoladas.

4. Lâmina foliar com face abaxial incana a levemente pubescente; inflorescência cauliflora, axilar nos ramos jovens, tirsiforme.......5.1.C. andromorpha

4'. Lâmina foliar com face abaxial velutina; inflorescência axilar, paniculada............... 5.3. C. pareira

3 '. Folhas peltadas, pecíolo inserido $2-12 \mathrm{~mm}$ da base; flores masc. com bráctea cordiforme.

5. Folhas glabras

5'. Folhas pilosas. 5.4. C. sympodialis

6. Folhas com 9 nervuras principais, lâmina com ambas as faces incanas ou seríceas

5.5. C. tropaeolifolia

6'. Folhas com 5-7 nervuras principais, lâmina com face abaxial pubescente a velutina

5.6. Cissampelos sp.

1'. Planta pistilada, com fruto.

7. Erva ereta $<80 \mathrm{~cm}$ alt 5.2. C. ovalifolia

7'. Liana $>1 \mathrm{~m}$ alt.

8. Folhas não peltadas.

9. Lâmina com face abaxial incana a levemente pubescente; inflorescência cauliflora, axilar nos ramos jovens, brácteas lanceoladas.

5.1. C. andromorpha

9'. Lâmina com face abaxial velutina; inflorescência axilar, brácteas cordiformes ... 5.3. C. pareira

8 '. Folhas peltadas, com pecíolo inserido $2-12 \mathrm{~mm}$ da base.

10. Lâmina foliar glabra, nervuras principais 10-12 5.4. C. sympodialis

10'. Lâmina foliar pilosa, nervuras principais 5-9.

11. Flor fem. com pedicelo e sépala glabra; drupa pubescente. 5.5. C. tropaeolifolia

11'. Flor fem. com pedicelo piloso e sépala pudescente; drupa glabra.. 5.6. Cissampelos sp.

\subsection{Cissampelos andromorpha DC., Syst. Nat. 1: 539.1818} [1817].

Figuras $10 \mathrm{~A}-\mathrm{O}$ e 11.

Nome popular: jarrinha, cocculos (Santos 4463).

Liana 4-6 $\mathrm{m}$ alt. Folhas cartáceas a membranáceas, levemente discolores, não peltadas; pecíolo $3-7,5 \mathrm{~cm}$ compr., incano, pulvino não torcido na base; lâmina 4-7,5 × 4,5-9 $\mathrm{cm}$, cordiforme, raro ovada, base subcordada a obtusa, margem inteira, ápice mucronado, obtuso a retuso, face adaxial glabra a incana, abaxial incana a levemente pubescente; nervuras principais 5-7. Inflorescência estaminada cauliflora, axilar nos ramos jovens, tirsiforme; raque 4-15 cm compr., pubescente; bráctea $0,3-1,2 \mathrm{~mm}$ compr., lanceolada, inserida na base do fascículo. Flores masc. al- 


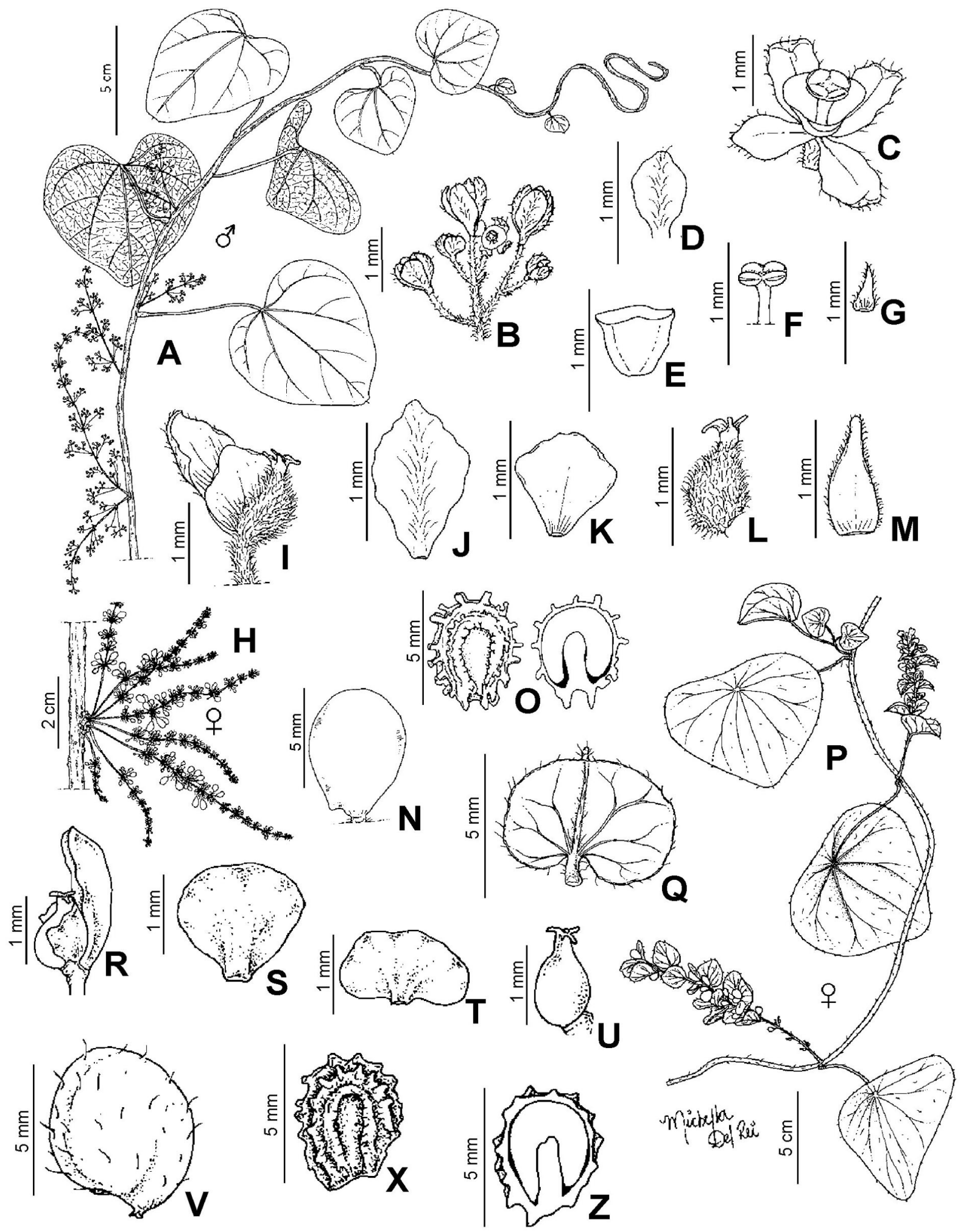

Figura 10. A-O. Cissampelos andromorpha: A- ramo com inflorescências estaminadas, B- detalhe de um ramo da inflorescência estaminada; C- flor masc.; D- sépala, vista abaxial; E- corola, vista lateral; F- sinândrio, vista lateral; G- bráctea, vista adaxial; H- ramo com inflorescências pistiladas; Iflor fem., vista lateral; J- sépala, vista abaxial; K- pétala, vista adaxial; L- carpelo, vista lateral; M- bráctea, vista adaxial; N- fruto, vista lateral; Oendocarpo, vista lateral (esq.) e corte longitudinal (dir.). P-Z. Cissampelos tropaeolifolia: P- ramo com inflorescência pistilada e infrutescência, Qbráctea, vista adaxial; R- flor fem., vista lateral; S- sépala, vista abaxial; T- pétala, vista abaxial; U- carpelo, vista lateral; V- fruto, vista lateral; Xendocarpo, vista lateral; Z- endocarpo, corte longitudinal (A-G- Hage 1408; H-M- Santos 2767; N-O- Del-Rei 45; P-Z-Del-Rei 60). 


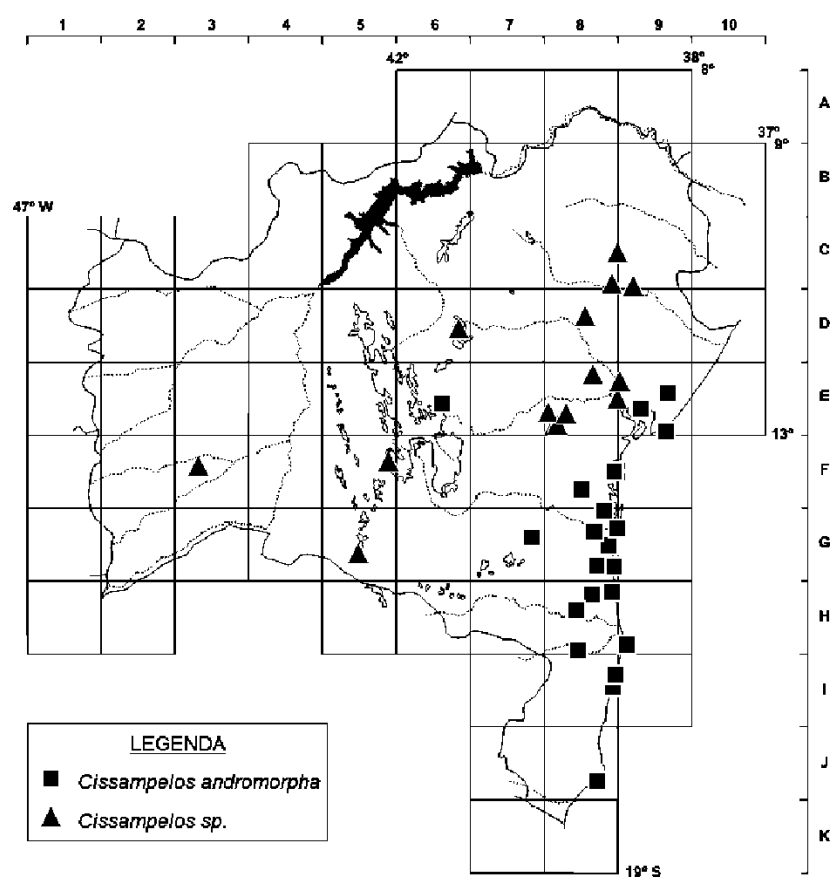

Figura 11. Distribuição geográfica de Cissampelos andromorpha e Cissampelos sp. no estado da Bahia.

vas; pedicelo 0,5-1,2 mm compr., pubescente; sépalas 0,8$1 \times$ ca. $0,5 \mathrm{~mm}$, oblanceoladas a obovadas, face abaxial pubescente, margem sinuada, ápice agudo a levemente agudo, involuto; corola 0,5-0,6 mm diâm., tubulosa a levemente campanulada, ápice sinuado, glabra; sinândrio 0,6-0,7 mm compr., anteras 4 . Inflorescência pistilada cauliflora, axilar nos ramos jovens, racemo simples; raque $6,5-21,5 \mathrm{~cm}$ compr., densamente pubescente; bráctea ca. 1,2 mm compr., lanceolada, margem inteira, ápice acuminado, pubescente. Flores fem. esverdeadas; pedicelo 1-2 mm compr., pubescente; sépalas 1,4-1,5 ×0,6-1,2 mm, elípticas, margem sinuada, involuta, ápice acuminado, pubescentes; pétalas $0,8-1,1 \times 0,9-1 \mathrm{~mm}$, obtruladas, margem inteira a levemente sinuada, ápice subagudo, glabras; carpelo ca. 1,1 $\times$ $0,5 \mathrm{~mm}$, ovário velutino, estigma trífido. Drupa 5-10 ×4-8 $\mathrm{mm}$, obovoide, madura laranja a vermelha; epicarpo glabro; endocarpo 3,6-9,5 × 2,5-6,3 mm; semente 3,3-9 × 2,2-6 $\mathrm{mm}$.

Ocorre em alguns países da América Central (Costa Rica, Guatemala e Panamá) e da América do Sul (Bolívia, Brasil, Colômbia, Equador, Guiana, Peru, Suriname e Venezuela) (Macbride 1938; Rhodes 1975; Ortiz 2001). No Brasil, está distribuída em estados das Regiões Norte, Nordeste, Centro-Oeste e em todos os estados das Regiões Sudeste e Sul (Rhodes 1975; Costa \& Sano 2007; Braga 2010). E6, E9, F8, G7, G8, H8, H9, I8, J8: Floresta Estacional Semidecidual e Floresta Ombrófila Densa Submontana. Coletada com flores masc. em fevereiro, março, maio e de agosto a dezembro, flores fem. em março, maio e de setembro a novembro e com frutos em janeiro, fevereiro, abril, maio, agosto, novembro e dezembro.

Material selecionado - Arataca, $15^{\circ} 10^{\prime} 25^{\prime \prime} \mathrm{S}, 39^{\circ} 20^{\prime} 30^{\prime \prime} \mathrm{W}$ 7 fev. 2009 (fr.), M. Del-Rei et al. 45 (CEPEC); Belmonte, 24 nov. 1970 (fl. masc.), T.S. Santos 1143 (CEPEC, RB); Boa Nova, $14^{\circ} 23,630^{\prime} \mathrm{S}, 40^{\circ} 8,722^{\prime} \mathrm{W}, 25$ out. 2001 (fl. masc.), W.W. Thomas et al. 12635 (CEPEC, NY n.v.); Cairu, 13 ago. 1993 (fr.), M.L. Guedes s.n. (ALCB 26015); Camacan, 16-20 jun. 2009 (est.), $M$. Del-Rei et al. 53 (CEPEC); Camamu, 1401'52”'S, 39¹0'31'W, 12 nov. 1983 (fl. fem. e fr.), J.L. Paixão et al. 299 (CEPEC); Caravelas, 18 ago. 1961 (fl. masc.), A.P. Duarte 5907 (RB); Feira de Santana, $12^{\circ} 25^{\prime} 35^{\prime}$ 'S, 38¹8'42'W, 17 fev. 1983 (fl. masc.), L.R. Noblick et al. 2583 (CEPEC, HRB, HUEFS, RB); Gandu, 19 maio 1993 (fl. masc.), C. Kameyama \& G.L. Esteves 73 (SPF); Ilhéus, $14^{\circ} 47^{\prime} 20^{\prime \prime}$ 'S, 3902'58''W, 20 nov. 2003 (fr.), L.A. MattosSilva et al. 4787 (ALCB, CEPEC, HUESC); Itabuna, 30 nov. 1970 (fl. fem. e fr.), L.E. Mello-Filho et al. 3033 (CEPEC, 7946); Itacaré, 17 out. 1997 (fl. masc.), J.G. Jardim et al. 1136 (CEPEC); Itapebi, 12 ago. 1971 (fl. masc.), T.S. Santos 1776 (CEPEC); Lençóis, $12^{\circ} 33^{\prime}$ S, $41^{\circ} 23^{\prime} \mathrm{W}, 8$ dez. 2007 (fl. masc.), M.L. Guedes et al. 14252 (ALCB); Porto Seguro, 21 set. 1971 (fl. masc.), T.S. Santos 1972 (CEPEC); Salvador, 1300'19”'S, 38³0'20’W, 30 mar. 2008 (fl. fem.), A.T. Nunes et al. 95 (ALCB); Santa Cruz Cabrália, 1 out. 1971 (fl. masc.), A. Eupunino 15 (CEPEC); São Francisco do Conde, 4 maio 1991 (fr.), F.P. Bandeira s.n. (ALCB 22735); Ubaitaba, 31 ago. 1970 (fl. fem. e fr.), T.S. Santos 1038 (CEPEC); Una, 22 fev. 2009 (fr.), R.O. Perdiz et al. 353 (CEPEC); Uruçuca, 14²9'59''S, 39॰06'54'W, 12 dez. 2004 (fr.), A.M. Amorim et al. 4509 (CEPEC).

Cissampelos andromorpha distingue-se das demais espécies do gênero pelas inflorescências caulifloras, axilares nos ramos jovens, além da ausência de brácteas vistosas e conspícuas, cobrindo as flores e frutos. Quando em estado vegetativo, pode ser confundida com $C$. pareira, porém esta última apresenta caule velutino, folhas persistentes nos ramos adultos e lâminas foliares com a face adaxial incana a pilosa e a abaxial velutina, enquanto $C$. andromorpha possui caule glabro, folhas apenas nos ramos jovens e lâminas foliares com a face adaxial glabra ou incana e a abaxial incana a levemente pubescente. Verifica-se ainda no caule desta espécie a presença de pequenos nódulos de onde surgem as inflorescências, característica não observada em C. pareira.

\subsection{Cissampelos ovalifolia DC., Syst. Nat. 1: 537. 1818 \\ [1817].}

Figuras 12 e 13.

Erva xilopodial ereta, $30-80 \mathrm{~cm}$ alt. Folhas cartáceas a subcoriáceas, discolores, peltadas nos ramos jovens; pecíolo 3-15 mm compr., velutino a tomentoso; lâmina 2-9,5 × 2-7 $\mathrm{cm}$, ovada a orbicular, às vezes reniforme a oblonga, base subcordada a arredondada, obtusa, margem inteira a levemente ondulada, ápice mucronado, arredondado a retuso, face adaxial glabra a pubescente, às vezes velutina, abaxial densamente velutina, tricomas alvos; nervuras principais 5. Inflorescência estaminada axilar, às vezes terminal, 


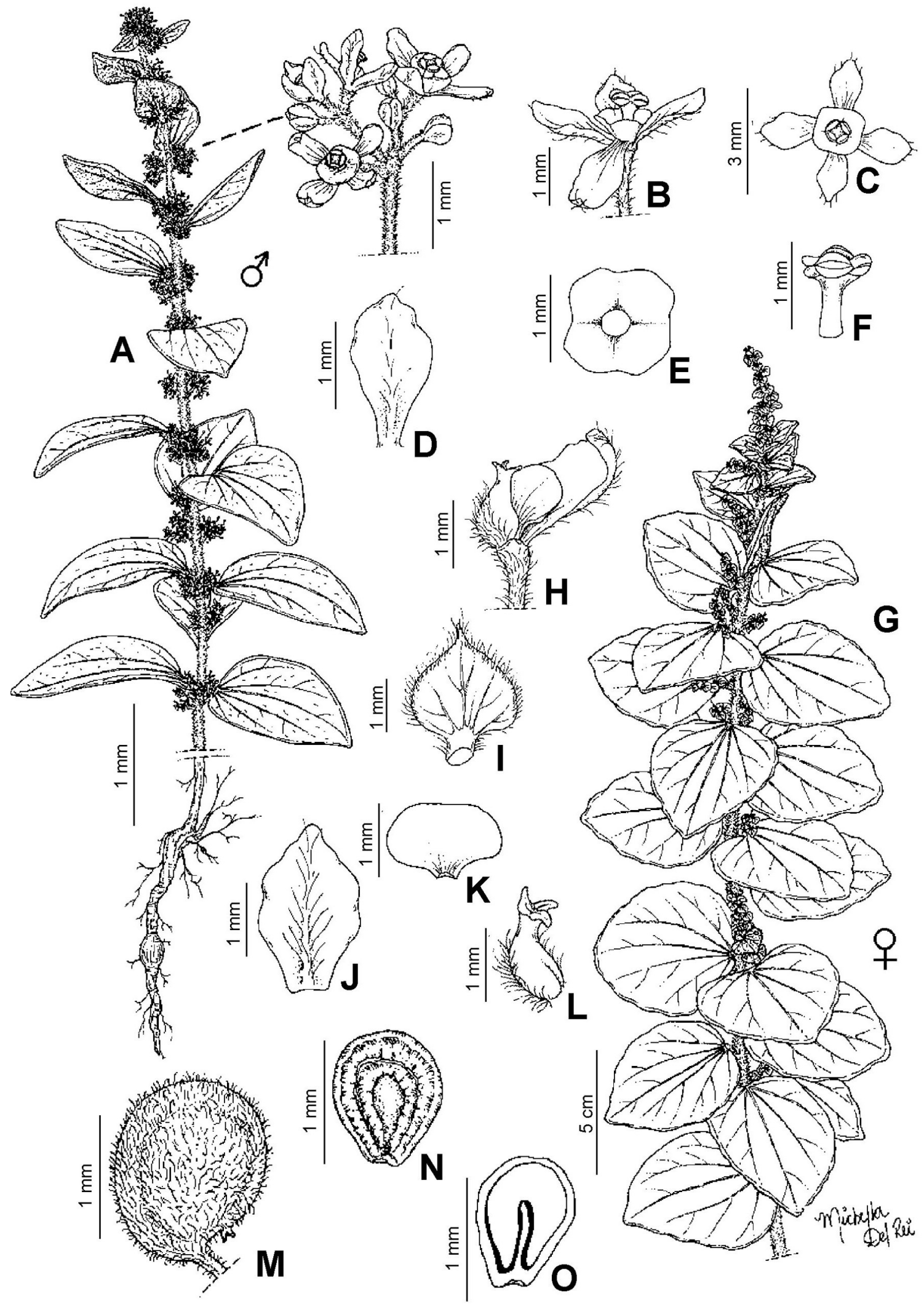

Figura 12. Cissampelos ovalifolia: A- ramo com inflorescências estaminadas, com detalhe de um ramo da inflorescência, B- flor masc., vista lateral; Cflor masc., vista adaxial; D- sépala, vista abaxial; E- corola, vista adaxial; F- sinândrio, vista lateral; G- ramo com inflorescências pistiladas; H- flor fem., vista lateral; I- bráctea, vista adaxial; J- sépala, vista abaxial; K- pétala, vista adaxial; L- carpelo, vista lateral; M- fruto, vista lateral; N- endocarpo, vista lateral; O- endocarpo, corte longitudinal (A-F- Del-Rei 58; G-O-Del-Rei 57). 
M. D. R. Teixeira \& A. M. A. Amorim - Menispermaceae da Bahia

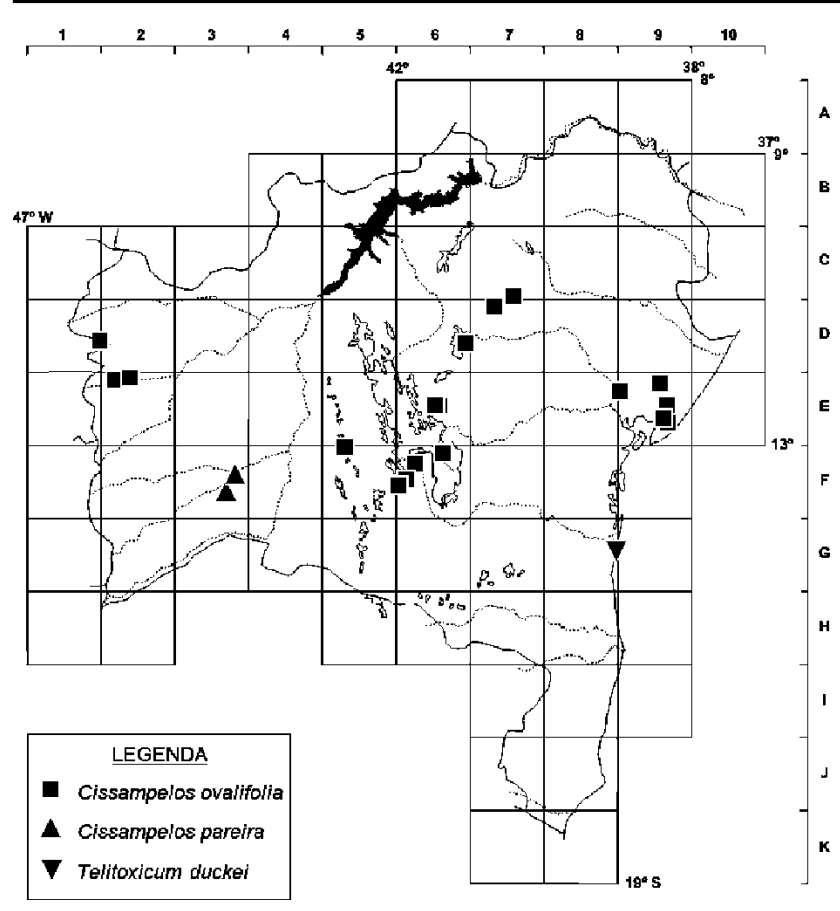

Figura 13. Distribuição geográfica de Cissampelos ovalifolia, C. pareira e Telitoxicum duckei no estado da Bahia.

paniculada; raque 1-2,5 cm compr., velutina; brácteas $0,3-$ $0,5 \mathrm{~mm}$ compr., lanceoladas. Flores masc. verde-amareladas; pedicelo 1-2 mm compr., glabro a levemente piloso; sépalas 4(5), 1,8-2,1 × 0,8-1,2 mm, espatuladas, oblanceoladas a obovadas, glabras a levemente pubescentes, margem sinuada, involuta, ápice arredondado a cuneado; corola 1,6-1,8 mm diâm., rotada, margem inteira; estames $0,5-0,7 \mathrm{~mm}$ compr., anteras 4 . Inflorescência pistilada axilar, racemo simples; raque 3-5 cm compr., velutina; brácteas 2,2-4 × 2,6-4,1 mm, cordadas. Flores fem. verde-amareladas; pedicelo 1,4-1,5 mm compr., velutino; sépala 2-2,2 $\times$ 1,5-1,6 mm, espatulada, pubescente a velutina, margem sinuada, ápice acuminado, involuta; pétala ca. 0,9 × 1,6-1,8 $\mathrm{mm}$, reniforme, glabra, margem inteira, ápice truncado a levemente retuso; carpelo 1,5-3 ×0,6 mm, ovário velutino, estilete ca. 0,6 mm compr., estigma trífido. Drupa 6-8 ×4$8 \mathrm{~mm}$, obovoide, madura vermelha; epicarpo pubescente; endocarpo 5-8 × 3-5 mm; semente 4,8-7,7 × 2,8-4,8 $\mathrm{mm}$.

Ocorre em alguns países da América do Sul (Bolívia, Brasil, Colômbia, Guiana, Paraguai, Suriname e Venezuela) (Rhodes 1975). No Brasil, ocorre em estados da Região Norte, Nordeste, Sudeste, Sul e em todos os estados do Centro-Oeste (Rhodes 1975; Braga 2010). C7, D1, D2, D6, D7, E2, E6, E8, E9, F5, F6: encontrada em cerrados, campos rupestres e nas Florestas Estacionais Semidecidual e Decidual. Coletada com flores masc. e fem. o ano inteiro, e com frutos de fevereiro a maio, em julho, novembro e dezembro.

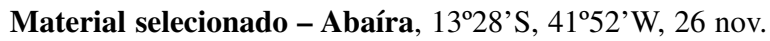
1993 (fl. fem. e fr.), W. Ganev 2575 (HUEFS); Alagoinhas, 26 set. 2009 (fl. masc.), M. Del-Rei et al. 59 (HUEFS); Barreiras, $13^{\circ} 25^{\prime} 36,5$ 'S, 4440'37,6”'W, 2 nov. 2009 (fl. fem.), M. Del-Rei et al. 88 (HUEFS); Érico Cardoso, 13³1'S, 420'W, 15 dez. 1988 (fr.), R.M. Harley et al. 27192 (CEPEC); Feira de Santana, 16 jul. 2009 (fl. fem. e fr.), M. Del-Rei 57 (HUEFS); Formosa do Rio

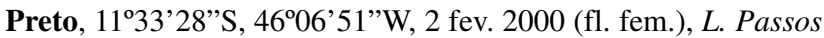
et al. 358 (CEPEC); Jacobina, $11^{\circ} 05^{\prime} \mathrm{S}, 40^{\circ} 40^{\prime} \mathrm{W}, 13$ abr. 1999 (fl. fem.), L.P. Queiroz et al. 5501 (ALCB, HST); Lamarão, $12^{\circ} 37^{\prime}$ '”'S, 38²2'44”W, 10 jul. 1994 (fl. fem.), M.L. Guedes et al.

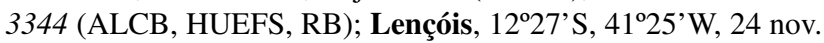
1994 (fl. masc.), E. Melo et al. 1340 (ALCB, CEPEC, HRB, HUEFS); Luís Eduardo Magalhães, 29 nov. 2003 (fl. fem.), A.B. Xavier 232 (ALCB, HRB); Macaúbas, 26 nov. 2004 (fl. fem.), G. Hatschbach 78577 (MBM); Morro do Chapéu, 11³5'44"S, 4104'05"'W, 9 mar. 2003 (fr.), L.P. Queiroz et al. 7666 (HUEFS); Mucugê, 1306'S, 41 $22^{\circ}$ 'W, 25 mar. 1980 (fl. fem.), R.M. Harley et al. 20963 (CEPEC); Palmeiras, 12²6'S, 41²2' 'W, 28 dez. 1994 (fl. fem.), M.L. Guedes et al. 1465 (ALCB, CEPEC, HUEFS); Piatã, $13^{\circ} 15^{\prime}$ S, $41^{\circ} 45^{\prime} \mathrm{W}, 16$ out. 1992 (fl. masc.), W. Ganev 1236 (HUEFS); Pindobaçu, 1056'36”'S, 40²4'28”'W, 10 abr. 2001 (fl. fem. e fr.), T. Ribeiro et al. 207 (ALCB, CEPEC, HUEFS); Pojuca, 20 mar. 2010 (fl. masc.), M. Del-Rei et al. 102 (HUEFS); Rio de Contas, 11 fev. 2010 (fl. fem. e fr.), M. Del-Rei et al. 94 (HUEFS); Salvador, $12^{\circ} 41^{\prime}$ 'S, $38^{\circ} 19^{\prime} \mathrm{W}, 15 \mathrm{dez} .2001$ (fl. masc.), J. Lima s.n. (ALCB 61466).

Cissampelos ovalifolia é a única espécie do gênero que apresenta hábito herbáceo ereto e xilopódio. Além disso, distingue-se das demais espécies estudadas pelos pecíolos velutinos a tomentosos, menores que $1,5 \mathrm{~cm}$ compr.

\subsection{Cissampelos pareira L., Sp. Pl.: 1031. 1753.}

Figuras 13 e 14.

Liana 4-5 m alt. Folhas membranáceas, levemente discolores, não peltadas; pecíolo $2-5 \mathrm{~cm}$ compr., velutino a tomentoso, pulvino não torcido; lâmina cordiforme, 4-4,5 $\times$ $5-5,5 \mathrm{~cm}$, base subcordada a obtusa, margem inteira, ápice mucronado, obtuso a retuso, face adaxial glabra a incana, abaxial velutina; nervuras principais 5-7. Inflorescência estaminada axilar, paniculada; raque 3-8 cm compr., velutina; brácteas 1-1,2 mm compr., lanceoladas, densamente velutinas. Flores masc. verde-amareladas; pedicelo 0,3-0,5 mm compr., velutino; sépalas 1-1,2 $\times 0,6-0,7 \mathrm{~mm}$, obovadas, membranáceas, velutinas, involutas, margem sinuada, ápice arredondado; corola $0,8-1 \mathrm{~mm}$ diâm., tubular, margem inteira; estames $0,3-0,5 \mathrm{~mm}$ compr., anteras 4 . Inflorescência pistilada axilar, em racemo simples; brácteas 5-8 × 5-10 $\mathrm{mm}$, cordiformes, cobrindo parcialmente os frutos maduros, face adaxial incana, abaxial velutina. Flores fem. não observadas; pedicelo 1-3 mm compr. no fruto, pubescente. Drupa 5,2-6,3 × 4-5 mm, obovoide, imatura verde a laranja, madura vermelha; epicarpo esparsamente piloso, às vezes glabro; endocarpo 5-6 × 3,5-4,6 mm; semente 3-5 × 34,2 $\mathrm{mm}$.

Ocorre nas Américas do Norte, Central e do Sul, Ásia e África (Rhodes 1975). No Brasil, ocorre em estados das Regiões Norte, Nordeste, Sudeste e nas Regiões CentroOeste e Sul (Braga 2010). F3: Floresta Estacional Semidecidual e no cerrado. Coletada com flores masc. em 


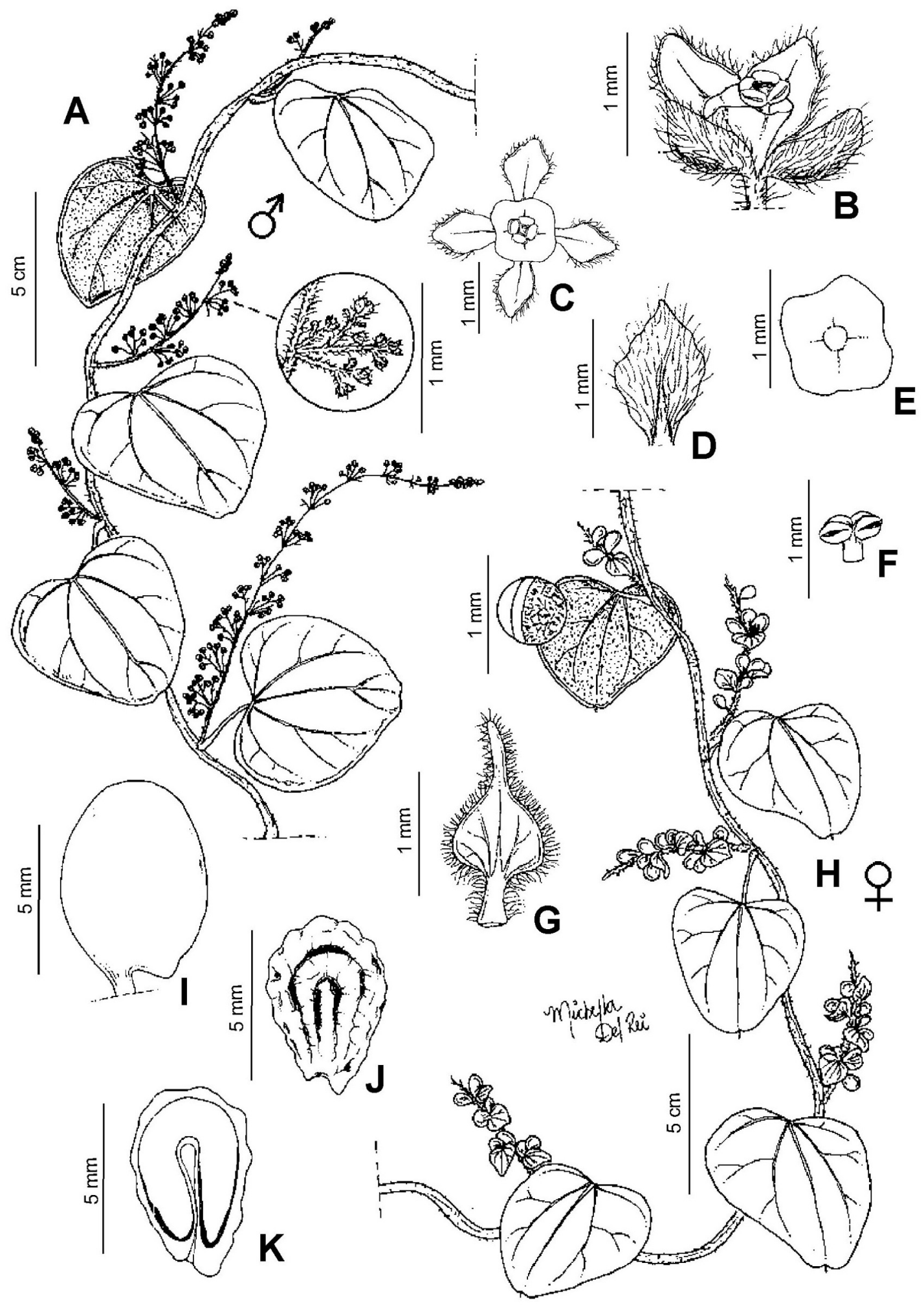

Figura 14. Cissampelos pareira: A- ramo com inflorescências estaminadas com detalhe de um ramo da inflorescência; B- flor masc., vista lateral; Cflor masc., vista adaxial; D- sépala, vista abaxial; E- corola, vista adaxial; F- sinândrio, vista lateral; G- bráctea, vista adaxial; H- ramo com inflorescências pistiladas; I- fruto, vista lateral; J- endocarpo, vista lateral; K- endocarpo, corte longitudinal (A-G- Ferrucci 1010; H-K- Guedes 13582). 
junho e agosto e com frutos em julho.

Material selecionado - Cocos, $14^{\circ} 16^{\prime} 21^{\prime \prime}$ 'S , 4432'50'W, 24 set. 2007 (fr.), M.L. Guedes et al. 13582 (ALCB); ib., 11 ago. 1996 (fl. masc.), M.S. Ferrucci et al. 1010 (CEPEC, MBM, CTES);

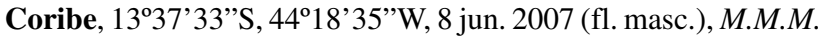
Lopes et al. 1374 (CEPEC).

Cissampelos pareira assemelha-se a Cissampelos $\mathrm{sp}$. pela forma e tamanho das folhas e pelas inflorescências pistiladas racemosas, podendo distinguir-se desta pelas folhas com pecíolo basifixo e inflorescências pistiladas com brácteas cobrindo parcialmente os frutos maduros, enquanto que Cissampelos sp. possui folhas peltadas e inflorescências pistiladas com brácteas cobrindo completamente os frutos maduros.

5.4. Cissampelos sympodialis Eichler, Flora 47: 392. 1864. Figuras 15 e 16.

Liana 1,5-2 $\mathrm{m}$ alt. Folhas cartáceas a membranáceas, levemente discolores; pecíolo 1,6-3 cm compr., piloso no ápice e na base, tricomas esparsos, inserido 0,6-1,2 cm da base, pulvino levemente torcido na base; lâmina 3-5,5 ×2,2$4,5(-5,5) \mathrm{cm}$, ovada, raro levemente cordiforme, base arredondada a levemente truncada, raro subcordada a cordada, margem inteira a levemente ondulada, ápice cuneado a acuminado, raro cuspidado a mucronado, as duas faces glabras; nervuras principais 10-12. Inflorescência estaminada axilar, em racemo composto; raque 8,5-20 cm compr., incano; brácteas 5-10 × 6-10 mm, cordiformes, glabras a levemente seríceas. Flores masc. verde-amareladas; pedicelo 1-1,5 $\mathrm{mm}$ compr., piloso; sépalas 4(5), obovadas a espatuladas, 3-3,3 × 1-1,1 mm, pilosa na face abaxial, raro glabra, margem levemente sinuada, ápice arredondado a retuso; corola $1-1,4 \mathrm{~mm}$ diâm., rotada a levemente campanulada, margem inteira, ápice arredondado; estames $0,5-0,7 \mathrm{~mm}$ compr. Inflorescência pistilada axilar, em racemo simples; raque 6,2-15 cm compr., pubescente; brácteas 6-12 × 7-14 mm, cordiformes, glabras a levemente ciliadas. Flores fem. verde-amareladas; pedicelo 1,5-2,1 $\mathrm{mm}$ compr., pubescente; sépala 2-2,2 × 1,4-1,5 mm, espatulada, membranácea, pilosa na face abaxial, margem sinuada, ápice arredondado, involuto; corola 0,9-1 × 1,5$1,6 \mathrm{~mm}$, reniforme, margem sinuada, ápice truncado; carpelo ca. $0,8 \times 0,7 \mathrm{~mm}$, ovário glabro, estigma trífido. Drupa 6-8 $\times 4,5-5,5 \mathrm{~mm}$, obovoide, imatura verde, madura vermelha; epicarpo glabro; endocarpo 5,2-7,3 × 4,2-5,3 $\mathrm{mm}$; semente 4,7-6,8 × 4-5 mm.

Endêmica do Brasil, ocorrendo em estados da Região Norte, Nordeste e Sudeste (Rhodes 1975; Barneby 1996; Braga 2010). C5, C7, D6, D7, D9, D10, E6, E8, E9, F4: cerrado, Floresta Estacional Semidecidual e Decidual. Coletada com flores masc. em fevereiro, março, de maio a julho e em outubro, com flores fem. em fevereiro, março, de outubro a dezembro e com frutos em março.

Material selecionado - Barra, $10^{\circ} 48^{\prime}$ S, $42^{\circ} 50^{\prime} \mathrm{W}, 22 \mathrm{fev}$. 1997 (fl. fem.), L.P. Queiroz 4781 (HUEFS); Bom Jesus da Lapa, 10 fev. 1968 (fl. masc.), A.L. Costa s.n. (ALCB 1215); Cachoeira, $12^{\circ} 32^{\prime}$ S, $39^{\circ} 05^{\prime}$ W, out. 1980 (fl. masc.), L. Scardino et al. in Gru- po Pedra do Cavalo 874 (ALCB, CEPEC, HUEFS, RB); Caldeirão Grande, $10^{\circ} 55^{\prime} \mathrm{S}, 40^{\circ} 18^{\prime} \mathrm{W}, 17$ nov. 1986 (fl. masc.), L.P. Queiroz 1166 (HUEFS); Esplanada, nov. 1950 (fl. fem.), G.C.P. Pinto 672 (IAC, RB); Jacobina, 12 jul. 1997 (fl. masc.), M.L. Guedes 4841 (ALCB); Morro do Chapéu, 11³5'43"'S, 40 57'08'W, 8 jun. 2001 (fl. masc.), E.R. Souza et al. 110 (HUEFS); Nova Redenção, $12^{\circ} 46^{\prime} 17^{\prime}$ 'S , 41 ${ }^{\circ} 09^{\prime} 58^{\prime \prime}$ 'W, 2 mar. 2003 (fl. fem. e fr.), L.R. Senna 141 (HUEFS); São Felix, 14 mar. 2010 (fl. masc.), M. Del-Rei et al. 95 (HUEFS); ib., 14 mar. 2010 (fl. fem. e fr.), M. Del-Rei et al. 97 (HUEFS); Seabra, 1048'34'S, 4243'38'W, 22 jun. 1996 (fl. masc.), R.M. Harley et al. 2934 (ALCB, CEPEC, HRB, RB).

Cissampelos sympodialis distingue-se das demais espécies estudadas do gênero principalmente pelas lâminas peltadas ovadas e glabras nas duas faces.

\subsection{Cissampelos tropaeolifolia DC., Syst. Nat. 1: 532.1818} [1817].

Figuras 10P-Z e 17.

Liana ca. 1,5 $\mathrm{m}$ alt. Folhas membranáceas, discolores; pecíolo 3-8 cm compr., piloso, inserido ca. $1 \mathrm{~cm}$ compr. da base, pulvino levemente torcido na base; lâmina 3-9 ×4-10 $\mathrm{cm}$, largo-elíptica a levemente cordiforme, base truncada a arredondada, margem inteira, ápice mucronado, faces adaxial e abaxial incanas a seríceas; nervuras principais 9 . Inflorescência estaminada axilar, racemosa, raro paniculada; brácteas $(2-) 6,3(-16) \times(2-) 7,7(-20) \mathrm{mm}$, cordadas a reniformes, pilosas, raro glabras (Rhodes 1975), ápice mucronado. Flores masc. verde-claras ou creme; pedicelo 1-2 mm compr., piloso; sépalas $(1-) 1,3(-2,4) \times$ $(0,9-) 1,1(-1,3) \mathrm{mm}$, elípticas a obovadas, glabras a externamente seríceas; corola $(0,4-) 0,8-1(-1,4) \mathrm{mm}$ diâm., campanulada, glabra; estames até ca. $0,5 \mathrm{~mm}$ compr. (Rhodes 1975). Inflorescência pistilada axilar, em racemo simples; raque 5-25 cm compr., pilosa; brácteas 5-13 × 6-20 mm, cordiformes, tricomas esparsos. Flores fem. verde-amareladas; pedicelo 1,2-3,2 mm compr., glabro; sépala 0,6-0,9 $\times 0,7-0,8 \mathrm{~mm}$, espatulada, glabra, margem sinuada, involuta, ápice arredondado; pétala $0,8-1 \times 0,6 \mathrm{~mm}$, reniforme, margem inteira, ápice truncado a levemente retuso; carpelo 1$1,1 \times 0,5 \mathrm{~mm}$, glabro, estigma trífido. Drupa 4-7 ×4-5 $\mathrm{mm}$, obovoide, madura verde-amarelada; epicarpo pubescente, tricomas esparsos; endocarpo 4,5-6 × 3-4 mm; semente 4-5,5 × 2,8-3,7 mm.

Ocorre em alguns países das Américas do Norte (México), Central (Costa Rica, Guatemala, Honduras, Nicarágua e Panamá) e do Sul (Bolívia, Brasil, Colômbia, Equador, Peru e Venezuela) (Rhodes 1975). No Brasil, é encontrada em estados das Regiões Norte, Nordeste, Centro-Oeste, Sudeste e Sul (Braga 2010). D10, E8, E9: Floresta Estacional Semidecidual e Floresta Ombrófila Densa Submontana. Coletada com flores fem. em maio, junho e setembro e com frutos em maio e setembro.

Material examinado - Cruz das Almas, 6 jun. 1987 (fl. fem.), G.C.P. Pinto 31 (CEPEC, HRB, HUEFS); Esplanada, 11\%46'33”S, 37'51'51,5”'W, 9 maio 2000 (fl. fem. e fr.), D.S. Lima et al. 72 (ALCB, HRB); São Sebastião do Passé, 19 set. 2009 (fl. fem. e 


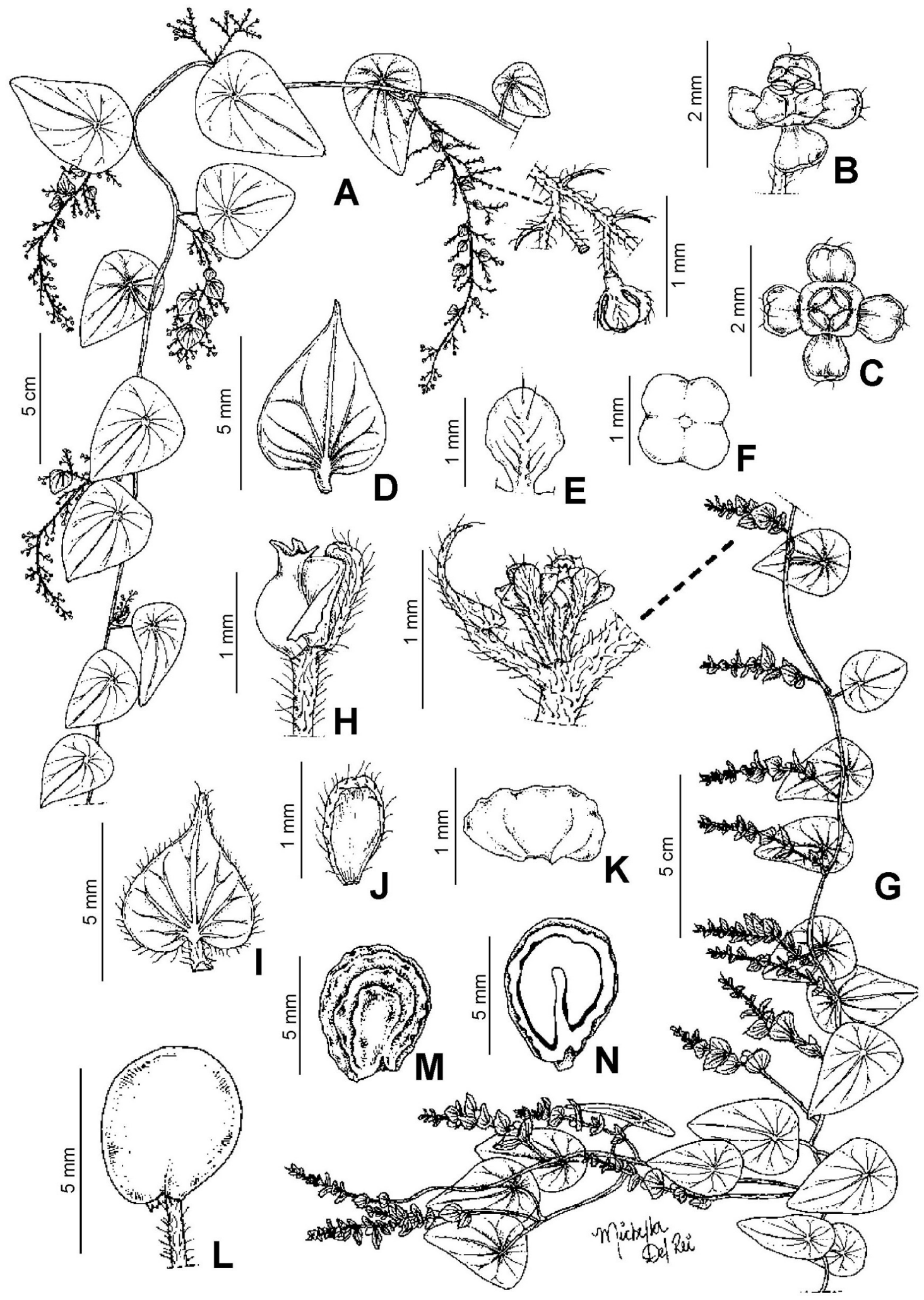

Figura 15. Cissampelos sympodialis: A- ramo com inflorescências estaminadas, com detalhe de um ramo da inflorescência; B- flor masc., vista lateral; C- flor masc., vista adaxial; D- bráctea, vista abaxial; E- sépala, vista abaxial; F- corola, vista adaxial; G- ramo com inflorescências pistiladas; H- flor fem., vista lateral; I- bráctea, vista abaxial; J- sépala, vista adaxial; K- pétala, vista abaxial; L- fruto, vista lateral; M- endocarpo, vista lateral; Nendocarpo, corte longitudinal (A-F- Del-Rei 95; G-N- Del-Rei 96). 
M. D. R. Teixeira \& A. M. A. Amorim - Menispermaceae da Bahia

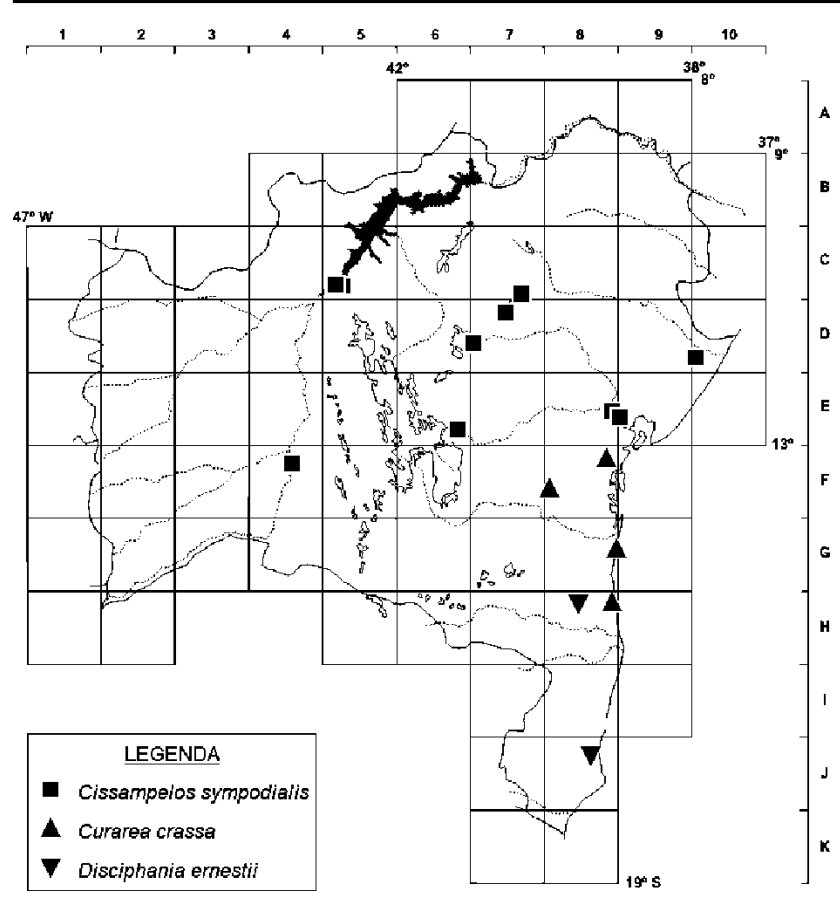

Figura 16. Distribuição geográfica de Cissampelos sympodialis, Curarea crassa e Disciphania ernestii no estado da Bahia.

\section{fr.), M. Del-Rei et al. 57 (HUEFS).}

Cissampelos tropaeolifolia assemelha-se a Cissampelos sp., mas distingue-se pelas folhas peltadas com pecíolo inserido ca. $1 \mathrm{~cm}$ da base, lâmina largamente elíptica a levemente cordiforme, incana a serícea nas duas faces e 9 nervuras principais, enquanto Cissampelos sp. possui folhas peltadas com pecíolo inserido $2-5 \mathrm{~mm}$ da base, lâmina cordiforme com face adaxial pubescente e abaxial pubescente a velutina e 5-7 nervuras principais.

\subsection{Cissampelos sp.}

Figuras 11 e 18.

Liana 1-2,5 m alt. Folhas membranáceas, levemente discolores; pecíolo 2-6 cm compr., delgado, pubescente a piloso, inserido $2-5 \mathrm{~mm}$ da base; pulvino levemente torcido no ápice; lâmina 2,5-6×2,5-6,5 cm, cordiforme, raro ovada, base levemente cordada, margem inteira, ápice mucronado a obtuso, face adaxial pubescente, abaxial pubescente a velutina; nervuras principais 5-7. Inflorescência estaminada axilar a terminal, paniculada; raque $8-9,5 \mathrm{~cm}$ compr., pilosa; brácteas 2,5-4,1 ×4,3-2,6 mm, cordiformes, pilosas. Flores masc. verde-claras ou amarelas; pedicelo 0,6$1 \mathrm{~mm}$ compr., piloso; 4(5) sépalas, 1,5-1,9 × 0,5-1,3 mm, oblanceoladas a obovadas, face abaxial pilosas, margem sinuada, ápice acuminado a cuspidado; corola 0,5-0,9 mm diâm., rotada, margem inteira; sinândrio 0,8-1,1 mm compr., anteras 4. Inflorescência pistilada axilar, racemo simples; raque 5,5-15 cm compr., pubescente a velutina; brácteas 5$15 \times 6-28 \mathrm{~mm}$, cordiformes, cobrindo os frutos maduros, pubescentes a velutinas. Flores fem. alvas; pedicelo 1,8-
2,6 mm compr., piloso, tricomas esparsos; sépala 1,5-1,9 $\times$ 0,6-1 mm, espatulada, pubescente, involuta, margem sinuada a crenulada, ápice acuminado a agudo; pétala 1,3-1,4 × ca. $1,4 \mathrm{~mm}$, reniforme, margem inteira, ápice truncado a levemente retuso; carpelo ca. $0,9 \times 0,4 \mathrm{~mm}$, glabro, estigma trífido. Drupa 5-7 × 4-5 mm, obovoide a subglobosa, madura vermelha; epicarpo glabro; endocarpo 4-5 × 2,7-3,8 $\mathrm{mm}$; semente 3,8-4,5 × 2,3-3,5 mm.

Os registros de Cissampelos sp. até o momento são restritos ao estado da Bahia. C8, C9, D6, D8, D9, E8, E9, F3, F5, G5: encontrada no cerrado, Caatinga e Floresta Estacional Semidecidual. Coletada com flores masc. em março, julho e novembro, flores fem. em todo o ano e com frutos de janeiro a maio e em novembro.

Material selecionado - Conceição de Feira, 17 mar. 2010 (fl. masc.), M. Del-Rei et al. 100 (HUEFS); ib., 17 mar. 2010 (fl. fem.), M. Del-Rei et al. 101 (HUEFS); Correntina, 13²5'36,5"S, 4440'37,6"W, 2 nov. 2009 (fl. masc.), M. Del-Rei et al. 87 (HUEFS); Érico Cardoso, 1322'S, 42 ${ }^{\circ} 06^{\prime}$ W, 14 jan. 2008 ( fl. fem. e fr.), A. Rapini et al. 1518 (HUEFS); Euclides da Cunha, $10^{\circ} 30^{\prime}$ S, 3900'W, 20 mar. 2004 (fl. fem. e fr.), M.L. Guedes et al. 10906 (ALCB); Feira de Santana, 16 jul. 2009 (fl. masc.), $M$. Del-Rei 55 (HUEFS); ib., 16 jul. 2009 (fl. fem.), M. Del-Rei 56 (HUEFS); Iaçu, 1242'S, 3956'W, 26 fev. 1983 (fl. masc.), H.P. Bautista 725 (ALCB, HUEFS); Itaberaba, 12 ${ }^{\circ} 53^{\prime}$ 'S, 39'52'W, 24 jan. 1980 (fl. fem.), R.M. Harley et al. 20530 (CEPEC); Itatim, $12^{\circ} 43^{\prime}$ S, 3942'W, 17 dez. 1995 (fl. fem.), E. Melo et al. 1431 (HUEFS, ESA); Licínio de Almeida, 14³7'38”S, 42³0'56”'W, 3 nov. 2006 (fl. fem.), A. Rapini et al. 1317 (HUEFS); Milagres, 1252'09'S, 3949'33”'W, 16 mar. 1997 (fl. fem.), F. França et al. 2170 (HUEFS); Morro do Chapéu, 4 mar. 1997 (fl. fem.), $P$. Gasson et al. 6022 (ALCB); Quijingue, 1055'39'S, 3904'51'W, 15 maio 2005 (fl. fem. e fr.), D. Cardoso et al. 549 (HUEFS);

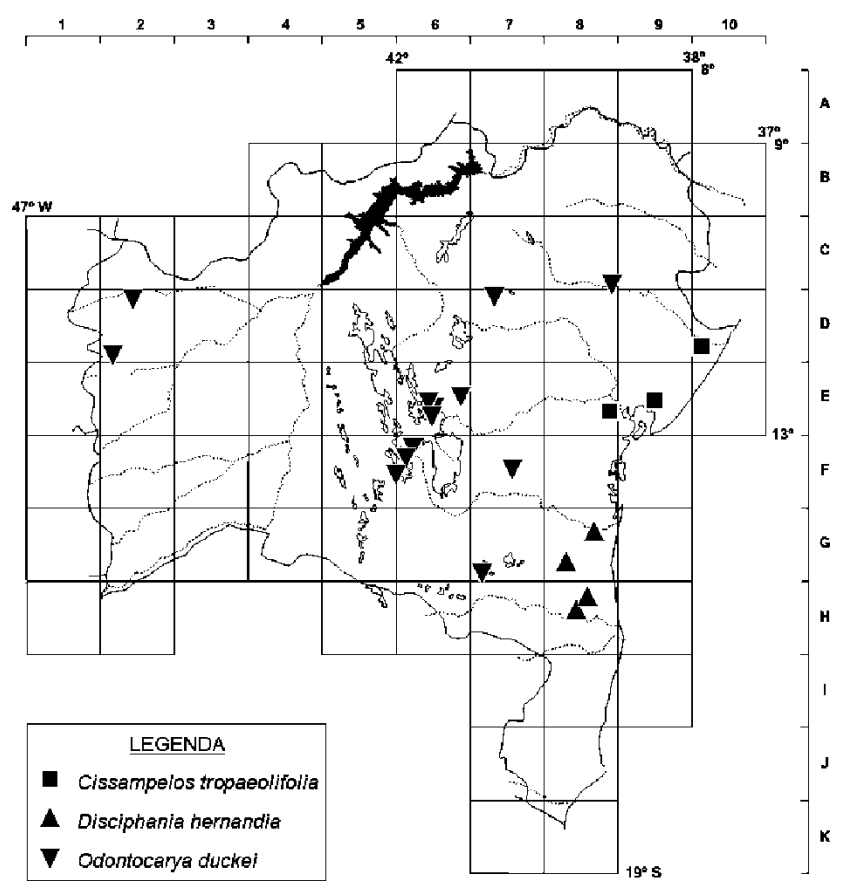

Figura 17. Distribuição geográfica de Cissampelos tropaeolifolia, Disciphania hernandia e Odontocarya duckei no estado da Bahia. 

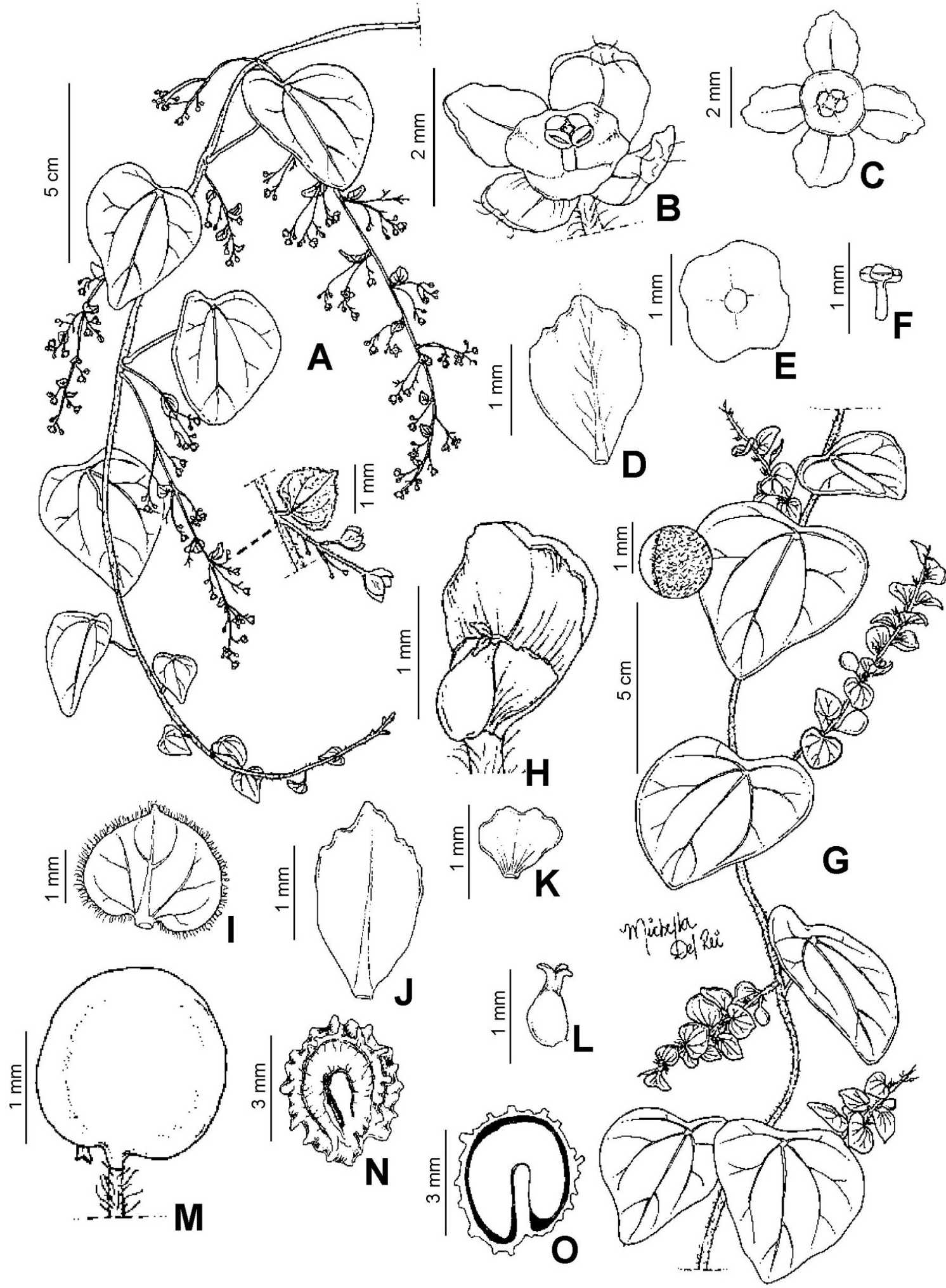

Figura 18. Cissampelos sp.: A- ramo com inflorescências estaminadas, com detalhe de um ramo da inflorescência; B- flor masc., vista lateral; C- flor masc., vista adaxial; D- sépala, vista abaxial; E- corola, vista adaxial; F- sinândrio; G- ramo com inflorescências pistiladas; H- flor fem., vista lateral; Ibráctea, vista adaxial; J- sépala, vista abaxial; K- pétala, vista adaxial; L- carpelo; M- fruto; N- endocarpo; O- endocarpo, corte longitudinal (A-F- DelRei 55; G-O- Del-Rei 56). 
M. D. R. Teixeira \& A. M. A. Amorim - Menispermaceae da Bahia

Serra Preta, $12^{\circ} 10^{\prime}$ 'S, 39²0'W, 17 jul. 1985 (fl. fem.), L.R. Noblick 4234 (HUEFS); Tucano, 1051'18”S, 3802'14”W, 21 abr. 2005

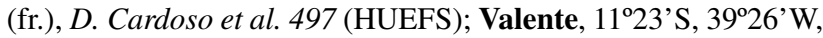
16 nov. 1986 (fl. masc.), L.P. Queiroz 1113 (HUEFS).

Cissampelos sp. possui caracteres morfológicos que a enquadram na descrição do complexo Cissampelos pareira. De acordo, com Rhodes (1975), C. pareira apresenta 81 sinônimos e possui a distribuição mais ampla dentre as espécies de Menispermaceae, o que dificulta uma compreensão abrangente de seus limites específicos. Cissampelos sp. difere de $C$. pareira principalmente pelo pecíolo inserido 2-5 $\mathrm{mm}$ da base da lâmina (vs. basifixo), inflorescências estaminadas pilosas, com brácteas cordiformes (vs. lanceoladas), flores masc. com sépala glabra a pilosa na face abaxial (vs. velutina) e infrutescências com brácteas cobrindo completamente os frutos (vs. cobrindo parcialmente os frutos maduros). Esses caracteres morfológicos diagnósticos estão incluídos nas exceções do complexo $C$. pareira e não foram encontrados espécimes semelhantes em outros estados, podendo se tratar de uma nova espécie. Devido à complexidade taxonômica e ampla distribuição geográfica de $C$. pareira, decidimos manter Cissampelos sp. como uma espécie à parte, sem no entanto descrevê-la como nova até que o gênero seja investigado em maior amplitude.

\section{Curarea Barneby \& Krukoff}

Liana. Folhas simples, não peltadas; lâmina discolor, face abaxial velutina a tomentosa, alva a ferrugínea, pálida; venação palmatinérvea, nervuras principais 3-9. Inflorescência estaminada axilar ou cauliflora, racemosa ou paniculada, geralmente menos ramificada que a fem.; brácteas diminutas. Flores masc. diclamídeas; sépalas 6(9), em 2(3) séries, densamente tomentosas, livres, as 3 externas, diminutas, as 3(-6) internas, maiores, com ápice revoluto; pétalas 6 , membranáceas, adnatas à base das sépalas; estames 6, livres, anteras rimosas. Inflorescência pistilada axilar ou cauliflora, geralmente racemosa ou tirso; brácteas diminutas. Flores fem. com sépalas semelhantes às das masc.; pétalas 3, alternas às sépalas maiores, subcartáceas; estaminódios ausentes; carpelos 3. Drupa com carpóforo geralmente curto, oblonga a obovoide; epicarpo membranáceo, geralmente tomentoso; mesocarpo geralmente fibroso; endocarpo em forma de U invertido, cartáceo, côndilo com intrusão lateral, lameliforme; semente curva, sem endosperma.

Curarea está posicionado na tribo Tiliacoreae Miers (Diels 1910; nome corrigido em Forman 1982). O gênero abrange cinco espécies com distribuição na América do Sul (Barneby \& Krukoff 1971; Barneby 1996). No Brasil, ocorrem quatro espécies, com registro em estados das Regiões Norte e Nordeste (Barneby \& Krukoff 1971; Krukoff \& Barneby 1974; Krukoff 1982; Barneby 1996; Braga 2010). Na Bahia, o gênero está representado apenas por Curarea crassa.
6.1. Curarea crassa Barneby, Brittonia 48(1): 22.1996. Figuras 16 e 19.

Liana 2-25 m alt. Folhas cartáceas a membranáceas; pecíolo 3,5-5,5 cm compr., velutino a tomentoso, com pulvino às vezes levemente torcido no ápice; lâmina 5,5-10 $\times 3,3-6,5 \mathrm{~cm}$, oblonga a elíptica, base obtusa a levemente arredondada, margem inteira, ápice arredondado a obtuso, face adaxial verde-escura, lustrosa, glabrescente, abaxial densamente velutina; nervuras principais 5-7. Inflorescência estaminada axilar, em racemo composto; raque $2,5-4,5 \mathrm{~cm}$ compr., densamente velutina. Flores masc. creme; pedicelo 1-2 mm compr., velutino; sépalas 9 em 3 séries, velutinas na face abaxial, as externas $0,7-0,8 \times 0,2-0,4 \mathrm{~mm}$, lineares a oblanceoladas, ápice acuminado, as internas 1-1,6 × 0,3$1,5 \mathrm{~mm}$, romboides a obovadas, margem inteira, ápice agudo, involuto; pétalas ca. $0,4 \times 0,5 \mathrm{~mm}$, largo-elípticas, levemente involutas face abaxial, velutinas no centro, margem inteira; estames ca. $0,5 \mathrm{~mm}$ compr., anteras introrsas. Inflorescência pistilada axilar, em tirso; raque $2-4,5 \mathrm{~cm}$ compr., velutina. Flor fem. creme; pedicelo até ca. $1 \mathrm{~mm}$ compr., velutino; sépalas 9 em 3 séries, velutinas, as externas $0,5-0,6 \times$ ca. $0,3 \mathrm{~mm}$, lineares a lanceoladas, ápice acuminado, as internas 1,5-2,1 ×0,9-1,5 mm, largo-elípticas, margem inteira, ápice ligulado, involuto; pétalas ca. 1,2 $\times$ 1,1-1,2 mm, flageladas, margem inteira, face adaxial velutina no centro; carpelo 1,6-1,8 × 0,6 mm, velutino. Drupa 30$45 \times 22-35 \mathrm{~mm}$, obovoide, madura verde-pálida, carpóforo 0,2-0,5 mm compr.; epicarpo com tricomas ferrugíneos; endocarpo 25-35 mm compr.; semente 24-33 mm compr.

Endêmica da Bahia (Barneby 1996; Braga 2010). F8, G8, H8: Floresta Ombrófila Densa Submontana e Floresta Estacional. Coletada com flores em janeiro, março e julho, e com frutos em fevereiro, abril, junho e julho.

Material selecionado - Jaguaquara, $13^{\circ} 34^{\prime} 48^{\prime \prime} \mathrm{S}$, $39^{\circ} 55^{\prime} 51^{\prime \prime} \mathrm{W}, 24$ abr. 2002 (fr.), R.P. Oliveira et al. 786 (HUEFS); Una, $15^{\circ} 09^{\prime}$ S, $39^{\circ} 05^{\prime} \mathrm{W}, 6$ jun. 1996 (fr.), W.W. Thomas et al. 6222 (CEPEC); Uruçuca, 14²5'S, 3901'W, 2 dez. 1993 (fr.), J.G. Jardim et al. 351 (holótipo CEPEC, isótipos K n.v., NY-foto).

Curarea crassa pode ser confundida com as espécies de Chondrodrendron estudadas, devido principalmente às folhas discolores com a face adaxial glabrescente e a abaxial alvo-velutina e à venação com mais de cinco nervuras principais. Porém, C. crassa distingui-se destas pelas flores masc. e fem. com nove (vs. 12 ou mais) sépalas, flores fem. com três (vs. 6) pétalas e três (vs. 6) carpelos, além da drupa velutina (vs. glabra), com carpóforo curto (vs. drupa estipitada). No presente trabalho, a descrição e a ilustração da flor fem. de C. crassa é feita pela primeira vez, e sua distribuição no estado é ampliada, com ocorrência registrada também em Floresta Estacional.

\section{Disciphania Eichler}

Liana sublenhosa. Folhas simples, raramente compostas, peltadas ou não; pecíolo com pulvino torcido na base; lâmina polimorfa, margem inteira a lobada; venação palmatinérvea, nervuras principais 3-9. Inflorescência 


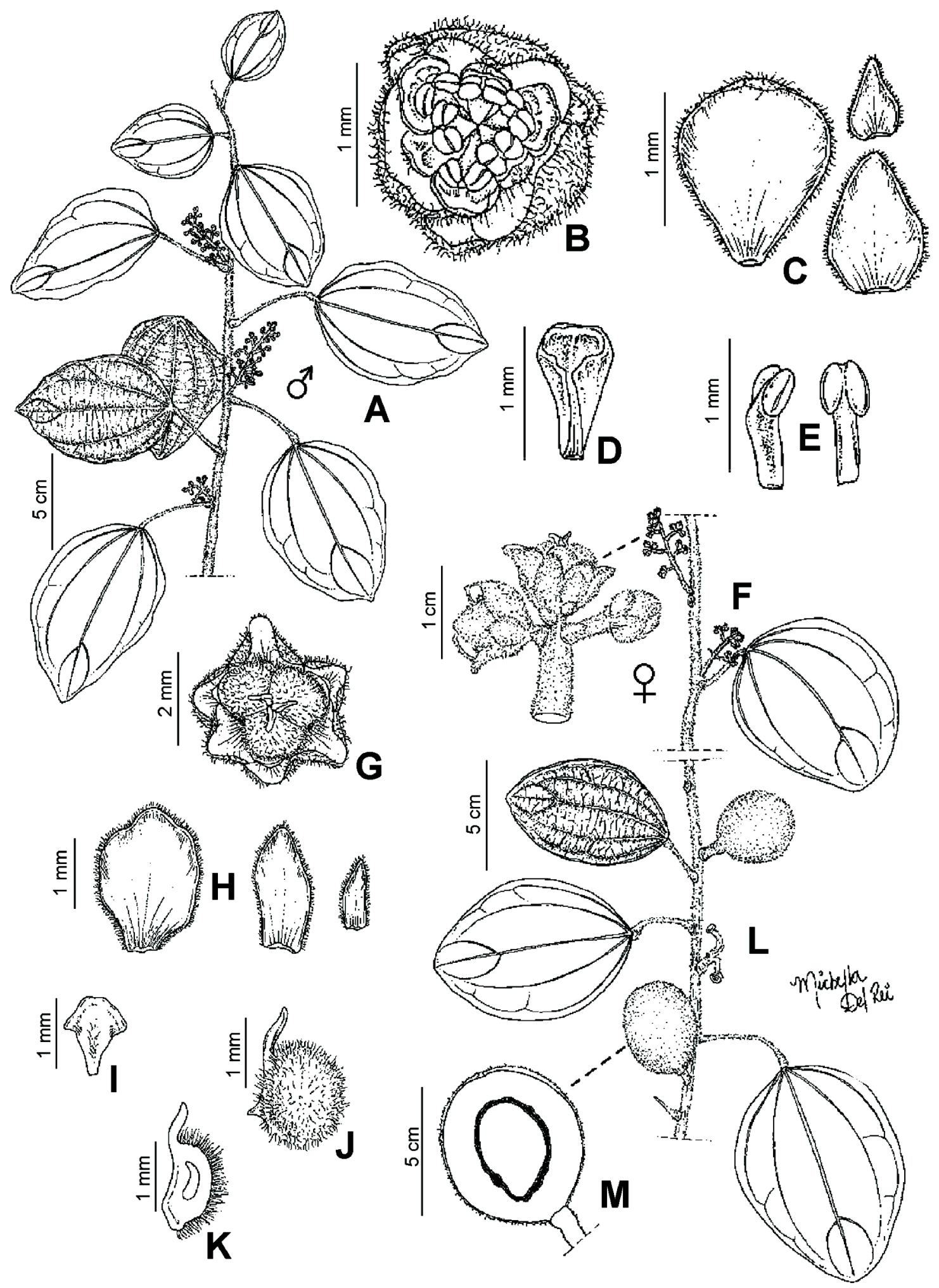

Figura 19. Curarea crassa: A- ramo com inflorescências estaminadas; B- flor masc., vista adaxial; C- sépalas, vários verticilos, vista adaxial; D- pétala, vista adaxial; E- estame, vista lateral (esq.) e adaxial (dir.); F- ramo com inflorescências pistiladas, com detalhe de um ramo da inflorescência; G- flor fem., vista adaxial; H- sépalas, vários verticilos, vista adaxial; I- pétala, vista adaxial; J- carpelo, vista lateral; K- carpelo, corte longitudinal; L- ramo com infrutescências; M- fruto, corte longitudinal (A-E- Paixão 1199; F-K- Jardim 609; L-M- Jardim 351). 
estaminada axilar, geralmente espiciforme, raramente racemosa ou flores solitárias; brácteas diminutas. Flores masc. diclamídeas; sésseis ou pediceladas; sépalas 6 em 2 séries, frequentemente carnosas, conatas somente na base ou até a metade do compr.; pétalas geralmente 6 , às vezes 3 , raro ausentes, geralmente carnosas, livres ou adnatas à base das sépalas; estames 3(-6), livres, anteras introrsas, deiscência rimosa ou transversal. Inflorescência pistilada axilar, geralmente espiciforme, semelhante à masc.; brácteas diminutas. Flores fem. com perianto semelhante ao das masc., muitas vezes menor; estaminódios ausentes; carpelos 3, livres, subglobosos, estigma diminuto, séssil. Drupa oblongo-elipsoide; epicarpo coriáceo; mesocarpo mucilaginoso, raro fibroso; endocarpo linear, cartilaginoso a crustáceo, elipsoide a ovoide, comprimido dorsiventralmente, geralmente com 8 costas longitudinais proeminentes ( 2 marginais, 1 dorsal, 1 ventral e 4 intercaladas para a margem), côndilo ausente; semente linear, oblongo-elipsoide, simétrica ou levemente assimétrica; endosperma liso.

Disciphania está posicionado na tribo Tinosporeae Miers (Diels 1910; nome corrigido em Forman 1982) e possui distribuição neotropical, com ca. 25 espécies (Barneby 1970). No Brasil, o gênero está representado por 10 espécies (4 endêmicas) e quatro variedades, com ocorrência em estados das Regiões Norte, Nordeste, Centro-Oeste, Sudeste e Sul (Braga 2010). Na Bahia, o gênero está representado por duas espécies.

\section{Chave para as espécies.}

1. Planta estaminada.

2. Folhas não peltadas, lâmina cordiforme, pubescente nas duas faces, base cordada; inflorescência com (9)10-35 flores, sépalas 5-9 mm compr. 7.1. D. ernstii

2. Folhas peltadas, lâmina ovada, glabra, base arredonda da a levemente truncada; inflorescência com 8-12 flores, sépalas ca. 2,4 mm compr. ..... 7.2. D. hernandia

1'. Planta pistilada, com frutos

3. Folhas não peltadas, lâmina cordiforme, pubescente nas duas faces, base cordada; flores fem. com sépalas ca. 2,9 mm compr. e pétalas 1,2-1,3 mm compr.; drupa com endocarpo cartilaginoso ...... 7.1.D. ernstii

3'. Folhas peltadas, lâmina ovada, glabra, base arredondada a levemente truncada; flores fem. com sépalas 1,3-1,8 mm compr. e pétalas $0,5-0,7 \mathrm{~mm}$ compr.; drupa com endocarpo crustáceo ...7.2. D. hernandia

7.1. Disciphania ernstii Eichl., Jahrb. Königl. Bot. Gart. Berlin 2: 329; tab. 12. 1883.

Figuras 16 e 20A-D.

Liana. Folhas cartáceas a membranáceas, discolores, não peltadas; pecíolo 3,5-6 cm compr., velutino a tomentoso; lâmina 6,6-11,5 × 6-9 cm, cordiforme, base cordada, margem inteira a levemente sinuada, ápice mucronado, pubescente em ambas as faces, a adaxial verde-escura, a abaxial mais clara e opaca; nervuras principais 5-7. Inflorescência estaminada supra-axilar, espiciforme, (9)1035 flores; raque 2,6-6 cm compr., glabra (Barneby 1970). Flores masc. alvas ou esverdeadas, sésseis; sépalas 5,5-9 $\times$ 1,8-6 mm, subcarnosas; pétalas 6 , ca. 1,5 × 1-2,5 mm, obdeltoides, em forma de disco, adnatas à base das sépalas; estames 3, 1,2-1,5 mm compr., filetes levemente curvos, conectivo dilatado, anteras introrsas, rimosas (Barneby 1970). Inflorescência pistilada axilar, espiciforme, 10-18 flores; raque 5-9 cm compr., glabra. Flores fem. verdes, sésseis; sépalas ca. 2,9 ×0,9-1,2 mm, elípticas, ápice agudo, face abaxial pilosa; pétalas $1,2-1,3 \times 0,5 \mathrm{~mm}$, estreitoelípticas, glabras, margem inteira, ápice acuminado; carpelos ca. 1,5 × 0,4-0,5 mm, ovoides, glabros. Drupa 15-18 × 11$15 \mathrm{~mm}$, madura vinácea; epicarpo glabro; mesocarpo mucilaginoso; endocarpo cartilaginoso, elipsoide; semente ca. $8 \times 4,5 \mathrm{~mm}$.

Ocorre na América Central (Panamá) e América do Sul (Brasil, Colômbia, Equador, Paraguai e Venezuela) (Macbride 1938; Barneby 1970). No Brasil, está distribuído em estados da Região Norte, Nordeste e Centro-Oeste (Barneby 1970; Braga 2010). H8, J8: Floresta Ombrófila Densa Submontana e Montana. Coletada com flores fem. em setembro e outubro, com frutos em fevereiro e outubro.

Material examinado - Jussari, 1509'29”'S, 39³1'43”W, 19 set. 2002 (fl. fem.), P. Fiaschi et al. 1089 (CEPEC); Prado, 17²15'S, $39^{\circ} 22^{\prime} \mathrm{W}, 20$ out. 1993 (fl. fem. e fr.), W.W. Thomas et al. 9961 (CEPEC).

Disciphania difere dos demais gêneros estudados pelas inflorescências espiciformes e drupas com endocarpo cartilaginoso. As duas espécies do gênero na Bahia podem ser distintas pelas folhas com pecíolo inserido na base, lâmina cordiforme, pubescente nas duas faces e drupas com endocarpo cartilaginoso (em Disciphania ernstii), e pelas folhas peltadas com lâmina ovada, glabra, e drupa com endocarpo crustáceo (em D. hernandia).

\subsection{Disciphania hernandia (Vell.) Barneby, Mem. New} York Bot. Gard. 22(4): 149. 1972.

Figuras 17 e 20E-I.

Liana ca. $2 \mathrm{~m}$ alt. Folhas cartáceas a membranáceas, levemente discolores; pecíolo 2,5-4 cm compr., glabro, inserida ca. 1,5 cm da base, pulvino às vezes torcido na base; lâmina 4,5-11,5 × 3-5,5 cm, ovada, base arredondada a levemente truncada, margem inteira, ápice acuminado, glabra; nervuras principais 7-9. Inflorescência estaminada espiciforme, 8-12 flores; raque 3-7 cm compr., glabra (Barneby 1970). Flores masc. alvas ou esverdeadas, sésseis; sépalas ca. 2,4 × 2,4 mm, ovado-deltoides, conatas até ca. 1,5 mm, reflexas, ápice agudo; pétalas 6, obdeltoides, adnatas até a base das sépalas, as 3 internas maiores; estames 3, ca. $1,8 \mathrm{~mm}$ compr., anteras introrsas, rimosas (Barneby 1970). Inflorescência pistilada espiciforme; raque $6,5-19 \mathrm{~cm}$ compr., glabra. Flores fem. verdes, sésseis; sépalas 1,3-1,8 $\times$ ca. $0,9 \mathrm{~mm}$, elípticas, livres, margem inteira, ápice arre- 


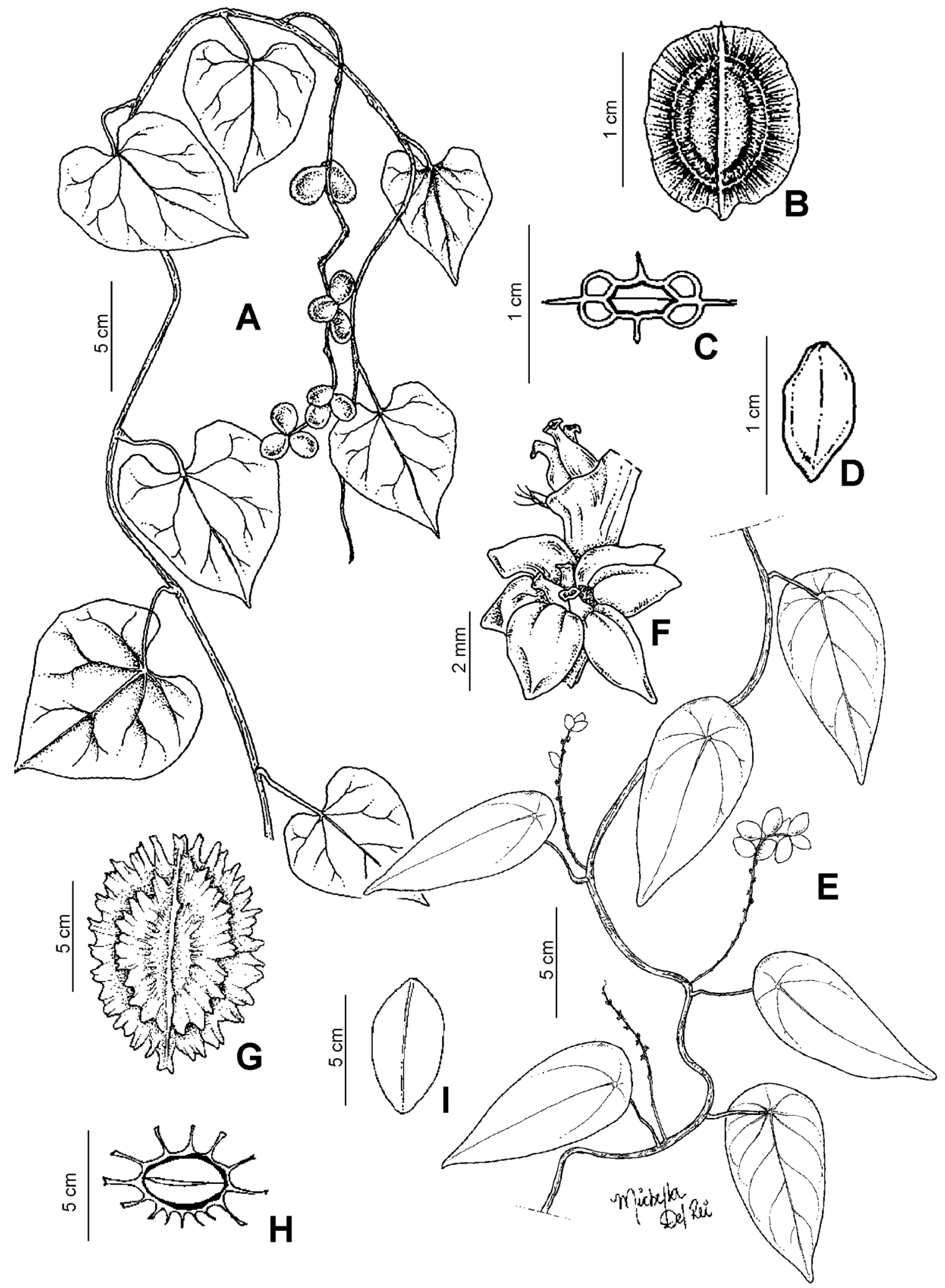

Figura 20. A-D. Disciphania ernstii: A- ramo com infrutescência; B- endocarpo, vista lateral; C- endocarpo, corte transversal; D- endosperma. E-I. Disciphania hernandia: E- ramo com inflorescências pistiladas e infrutescências; F- detalhe de um ramo da inflorescência pistilada; G- endocarpo, vista lateral; H- endocarpo, corte transversal; I- embrião (A-D- Jardim 4481; E-I- Santos 1039). 
dondado, as internas revolutas, glabras; pétalas $6,0,5-0,7 \times$ ca. $0,5 \mathrm{~mm}$, estreito-elípticas, adnatas à base das sépalas, glabras, margem inteira, ápice agudo a cuspidado; carpelos ca. 1,5 × 0,5-0,7 mm, ovoides, glabros. Drupa $18-22 \times$ 16-20 mm, ovoide-elipsoide, madura vermelha; epicarpo glabro; mesocarpo mucilaginoso; endocarpo 15-18 × ca. 15 $\mathrm{mm}$, crustáceo; semente 6-10 × 5-8 mm.

Endêmica do Brasil, onde ocorre apenas na Região Nordeste (Braga 2010). G8, H8: Floresta Ombrófila Densa Submontana e Montana. Coletada com flores em agosto e com frutos em janeiro e agosto.

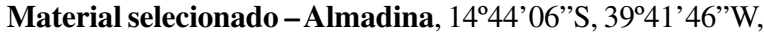
27 fev. 1997 (est.), J.G. Jardim et al. 1000 (CEPEC); Arataca, 15'12'10'S, 39²4'29'W, 21 jan. 2007 (fr.), R.A.X. Borges et al. 582 (CEPEC); Camacan, 16-20 jun. 2009 (est.), M. Del-Rei et al. 51 (CEPEC); Ubaitaba, 31 ago. 1970 (fl. fem e fr.), T.S. Santos 1039 (CEPEC, RB).

Disciphania hernandia pode ser confundida vegetativamente com Cissampelos sympodialis devido principalmente às folhas obovadas e peltadas, porém distinguese desta pela inflorescência pistilada espiciforme e flores fem. com seis sépalas, seis pétalas e três carpelos, enquanto C. sympodialis apresenta inflorescência pistilada em racemo e flores fem. com apenas uma sépala, uma pétala e um carpelo.

\section{Hyperbaena Miers ex Benth.}

Lianas, arbustos ou árvores. Folhas simples; pecíolo glabro a pubescente, geralmente com pulvino no ápice; lâmina concolor, coriácea, raramente membranácea, glabra a pubescente, venação peninérvea ou palmatinérvea. Inflorescência estaminada axilar, espiciforme ou paniculada, glabra ou pubescente; brácteas diminutas. Flores masc. diclamídeas; sépalas geralmente 6, em 2 séries, sépalas externas glabras, raro pubescentes, sépalas internas glabras, raro esparsamente pilosas; pétalas 6, raro ausentes, em 2 séries semelhantes; estames 6, raro 3-5, anteras introrsas, deiscência rimosa ou transversal. Inflorescência pistilada axilar, racemosa, espiciforme ou paniculada, glabra a pubescente; brácteas diminutas. Flores fem. com perianto semelhante ao das masc.; estaminódios ausentes; carpelos 2-5, obovoides ou globosos, estilete ausente, estigma lateral ou terminal. Drupa verde, amarela, laranja, vermelha, púrpura ou preta, globosa a obovoide; epicarpo glabro, raro piloso, subcoriáceo a coriáceo; mesocarpo delgado; endocarpo em forma de U invertido, coriáceo, côndilo com intrusão lateral, lameliforme; semente curva, endosperma ausente, embrião carnoso.

Hyperbaena está posicionada na tribo Hyperbaeneae Diels (Diels 1910), sendo o único representante da tribo no Brasil. O gênero é neotropical e possui 19 espécies (Mathias \& Theobald 1981). No Brasil, Hyperbaena está representado por três espécies com registro em estados das Regiões Norte e Nordeste e em toda a Região Sudeste e Sul (Braga 2010). Na Bahia, o gênero está representado por uma espécie.

\subsection{Hyperbaena domingensis (DC.) Benth., J. Proc. Linn.} Soc., Bot. 5(Suppl. 2): 50. 1861.

Figuras 21A-D e 22.

Liana 6-10 m alt. Folhas subcoriáceas, verde-amareladas, brilhantes nas duas faces; pecíolo $1-4,5 \mathrm{~cm}$ compr., glabro a levemente pubescente, pulvino torcido no ápice; lâmina 4,5-13,5 × 2-6,5 cm, ovada, elíptica a largo-elíptica, base levemente arredondada a obtusa, margem inteira, levemente revoluta, ápice agudo a acuminado, glabra; nervuras principais 3. Inflorescência estaminada paniculada; raque 4-20 cm compr., glabra a levemente velutina. Flores masc. esverdeadas; pedicelo 0,5-3 mm compr., glabro a levemente velutino; sépalas membranáceas, ápice arredondado, as externas ca. $0,6 \times 0,4 \mathrm{~mm}$, oblanceoladas a obovadas, margem sinuada, pilosas na face abaxial, raro glabras, as internas 0,8-1 × ca. 0,7 mm, ovadas, glabras, margem inteira; pétalas ca. $0,8 \mathrm{~mm}$ compr., obovadas a orbiculares, membranáceas, glabras, margem inteira; estames 6, 0,4-0,5 mm compr., livres, anteras introrsas, deiscência transversal. Inflorescência pistilada em racemo simples; raque 7-12 cm compr., 2-3 mm diâm., glabra a pilosa (Mathias \& Theobald 1981). Flores fem. amarelo-esverdeadas; pedicelo 0,5-1 cm compr., pubescente; sépalas glabras, as externas ca. $0,8 \times 0,5 \mathrm{~mm}$, obovadas, as internas ca. $1,2 \times 1 \mathrm{~mm}$, largamente ovadas; pétalas ca. $0,6 \times 0,4 \mathrm{~mm}$, largamente obovadas, glabras; carpelos 3 , ca. $0,8 \times 0,5 \mathrm{~mm}$, oblongoelípticos, glabros (Mathias \& Theobald 1981). Drupa 18 $21 \times 10-13 \mathrm{~mm}$, obovoide, madura púrpura; epicarpo glabro; endocarpo 15-18 × 10-11 mm, reticulado; semente 10-15 $\times 9-10 \mathrm{~mm}$.

Ocorre nas Américas Central e do Sul (Mathias \& Theobald 1981). No Brasil, está distribuída em estados das Regiões Norte e Nordeste e em toda a Região Sudeste e Sul (Mathias \& Theobald 1981; Nicolson et al. 1991; Braga 2010). H8, J8, K8: Floresta Ombrófila Densa Submontana e Montana. Coletada com flores . em abril, outubro e novembro e com frutos em junho e outubro.

Material selecionado - Arataca, 15 $10^{\circ} 27^{\prime \prime} \mathrm{S}, 39^{\circ} 20^{\prime} 22^{\prime \prime} \mathrm{W}$, 25 nov. 2006 (fl. masc.), A.M.A. Amorim et al. 6571 (CEPEC); Mucuri, 2 abr. 1971 (fl. masc.), T.S. Santos 1538 (CEPEC, RB); Prado, 1708'S, 39²5'W, 20 out. 1993 (fr.), W.W. Thomas et al. 10024 (CEPEC, HUESC, MBM); Teixeira de Freitas, 11 out. 1971 (fl. masc.), T.S. Santos et al. 2106 (CEPEC, RB).

Como mencionado anteriormente, Hyperbaena domingensis assemelha-se a Abuta selloana e Borismene japurensis, porém difere de A. selloana por apresentar pulvino delgado no ápice, flores diclamídeas, drupa obovoide e semente sem endosperma; de B. japurensis, esta mesma espécie pode ser diferenciada pelas flores masc. com seis sépalas e semente sem endosperma.

\section{Odontocarya Miers}

Liana sublenhosa. Folhas simples, não peltadas; lâmina cordiforme, ovada a elíptica; venação palmatinérvea; nervuras principais 3-5; às vezes com domácias circulares ou elípticas entre as nervuras principais e nas axilas das 


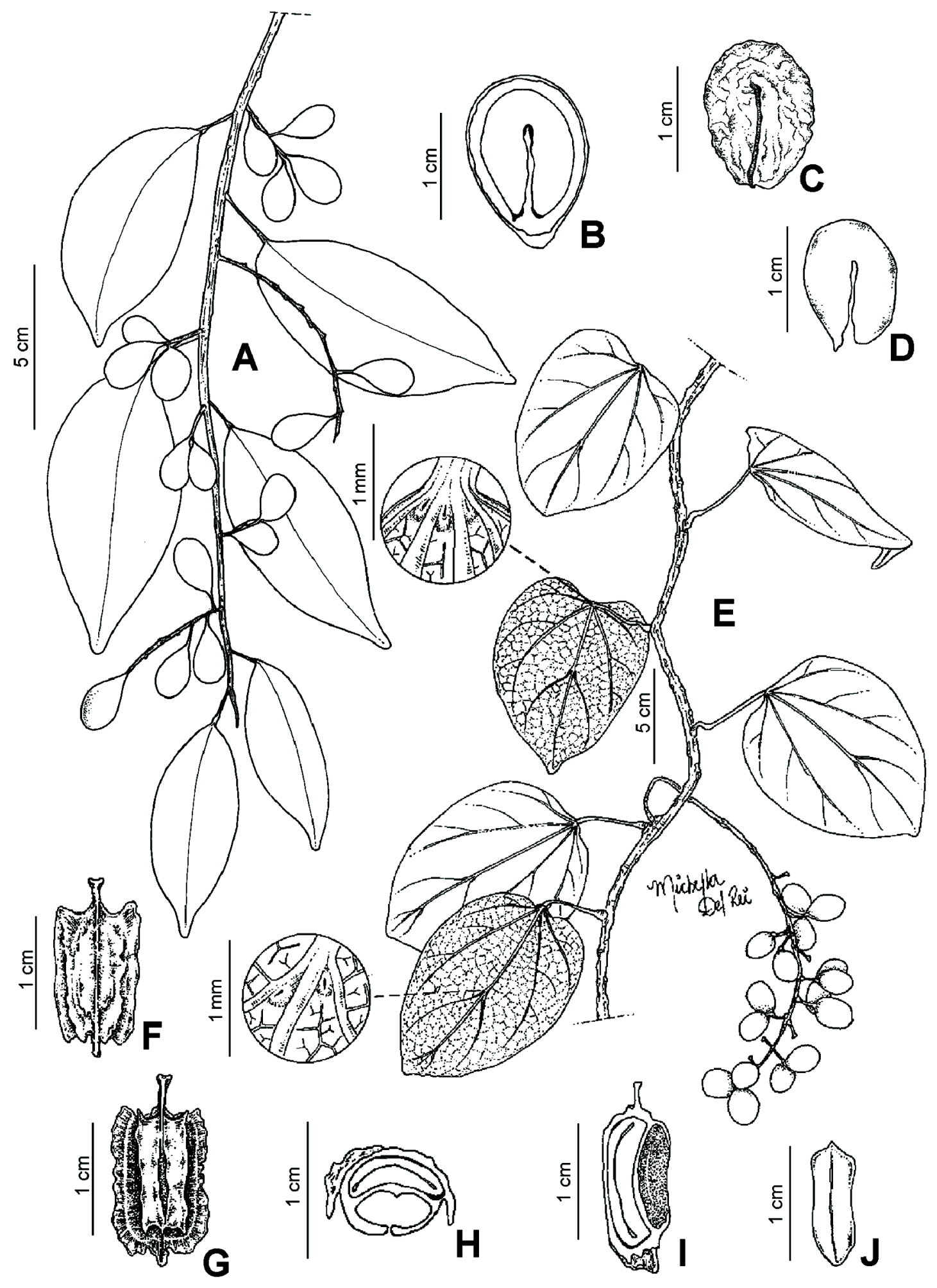

Figura 21. A-D. Hyperbaena domingensis: A- ramo com infrutescências; B- fruto, corte longitudinal; C- endocarpo, vista lateral; D- embrião. E-J. Odontocarya vitis: E- ramo com infrutescência, com detalhe das domácias; F- endocarpo, vista adaxial; G- endocarpo, vista abaxial; H- endocarpo, corte transversal; I- endocarpo, corte longitudinal; J- endosperma (A- Santos 2106; B-D- Thomas 10024; E-J- Thomas 11343). 
nervuras secundárias. Inflorescência estaminada axilar ou cauliflora, racemosa ou paniculada, geralmente fasciculada, fascículos com 2-5 flores; brácteas diminutas. Flores masc. diclamídeas; sépalas 6 em 2 séries, as externas muito menores que as internas; pétalas geralmente 6 , margem geralmente involuta; estames 6,3 ou 1, filetes lineares, conatos, raro livres, comumente os 3 internos em sinândrio, anteras extrorsas, deiscência rimosa, raro transversal. Inflorescência pistilada axilar, racemosa ou paniculada; brácteas diminutas. Flores fem. com perianto semelhante ao das masc.; estaminódios 3-6; carpelos (1-)3, glabros. Drupa geralmente elipsoide; epicarpo membranáceo a coriáceo, glabro; mesocarpo geralmente mucilaginoso com lamela fibrosa; endocarpo linear, geralmente elipsoide, dorsiventralmente assimétrico, dorsalmente arredondado, às vezes rugoso ou com cristas, geralmente dentado no ápice ou nas duas extremidades, às vezes verticalmente escavados, côndilo visível externamente, globular, arredondado, oval, linear, ou raro com abertura transversalmente elíptica; semente linear, endosperma ventralmente ruminado.

Odontocarya está posicionado na tribo Tinosporeae Hook.f. \& Thoms. (Diels 1910; nome corrigido em Forman 1982). O gênero possui ca. 30 espécies distribuídas na América Central (Costa Rica, Panamá e nas Antilhas) e na América do Sul (Argentina, Bolívia, Brasil, Colômbia, Paraguai, Peru e Venezuela) (Macbride 1938; Barneby 1970; Funk et al. 2007). No Brasil, ocorrem 21 espécies, com registro em estados das Regiões Norte, Nordeste, Centro-Oeste e Sul e em todos os estados da Região Sudeste (Barneby 1970; Braga 2010). Na Bahia, o gênero está representado por duas espécies.

\section{Chave para as espécies}

1. Planta estaminada.

2. Lâmina foliar 3,5-7,5 × 2,5-7 cm, cordiforme; flor masc. com 3 estames livres e 3 estames conatos $0,3-0,4 \mathrm{~mm}$ 9.1. O. duckei

2'. Lâmina foliar 6,5-10,5 × 4-8,5 cm elíptica a leve mente ovada; flor masc. com 6 estames livres ou conatos ca. $0,1 \mathrm{~mm}$ 9.2. O. vitis

1'. Planta pistilada, com fruto.

3. Lâmina foliar cordiforme, domácias entre as nervuras principais com abertura elíptica a levemente circular; drupa com endocarpo 5-10 mm compr., côndilo 1-3 mm compr. 9.1. O. duckei

3'. Lâmina foliar elíptica a levemente ovada, domácias entre as nervuras principais com abertura linear; drupa com endocarpo 12-17 mm compr., côndilo 5-6 mm compr. 9.2. O. vitis

9.1. Odontocarya duckei Barneby, Mem. New York Bot. Gard. 20(2): 92. 1970.

Figuras 17 e 23.

Liana 1-1,5 m alt. Folhas subcoriáceas, discolores; pecíolo 2-4,5 cm compr., glabro, pulvino levemente torcido na base; lâmina 3,5-7,5 × 2,5-7 cm, cordiforme, base cordada, margem inteira, ápice acuminado, glabras; nervuras principais 5 ; domácias entre as nervuras principais, às vezes na axila das nervuras secundárias, abertura elíptica a levemente circular. Inflorescência estaminada axilar, em racemo simples; raque 4-11 cm compr., glabra. Flores masc. creme; pedicelo 0,3-0,5 mm compr., glabro; sépalas glabras, as externas $0,4-0,8 \times$ ca. $0,5 \mathrm{~mm}$, ovadas a elípticas, as internas 1-1,5 × 0,8-1 mm, elípticas a levemente obovadas; pétalas $0,3-0,5 \times 0,3-0,5 \mathrm{~mm}$, ovadas, glabras, margem inteira; 6 estames, 0,5-0,6 mm compr., 3 livres e 3 com filetes conatos $0,3-0,4 \mathrm{~mm}$, anteras rimosas. Inflorescência pistilada axilar, racemo simples; raque $7,5-14,5 \mathrm{~cm}$, glabra. Flores fem. não observadas. Drupa 7-9 × 5-6 mm, elipsoide, madura laranja; endocarpo 5-10 ×5-6 mm, face adaxial levemente rugosa, côndilo ventral 1-3 ×0,8-1 mm, oval a elíptico; semente 4,6-9,7 × 4,8-5,7 mm.

Endêmica do Brasil, ocorre em estados das Regiões Norte, Nordeste, Centro-Oeste e Sudeste (Braga 2010). C8, D2, D7, E6, F5, F6, F7, G7: cerrados, campos rupestres e Floresta Estacional Semidecidual. Coletada com flores e frutos durante o ano todo.

Material selecionado - Abaíra, $13^{\circ} 19^{\prime} \mathrm{S}, 4^{\circ} 49^{\prime} \mathrm{W}, 24$ nov. 1992 (fl. masc.), R.M. Harley et al. 1548 (HUEFS); Barreiras, 11'52'55'S, 4549'42”'W, 5 set. 2005 (fl. masc.), E. Melo et al. 4021 (HUEFS, SP); Érico Cardoso, $13^{\circ} 31^{\prime}$ S, 42 ${ }^{\circ} 00^{\prime} \mathrm{W}, 17 \mathrm{dez}$. 1988 (fr.), R.M. Harley et al. 27550 (CEPEC, K n.v., MBM, RB, SPF); Formosa do Rio Preto, $11^{\circ} 06^{\prime} 33^{\prime \prime} S, 45^{\circ} 33^{\prime} 45^{\prime \prime} \mathrm{W}, 5$ abr. 2000 (fl. fem.), R.M. Harley et al. 53863 (HUEFS); Jacobina, 11'05'13"S, 4040'21'W, 2 jul. 1996 (fl. masc.), R.M. Harley et al. PCD 3292 (ALCB); Lençóis, 19 dez. 1984 (fr.), J.R. Pirani et al. CFCR 7259 (SPF); Maracás, 27 abr. 1978 (fr.), S.A. Mori et al. 10057 (CEPEC); Mucugê, 1243'51'S, 41³0'33'W, 16 abr. 2005 (fl. fem. e fr.), A.A. Conceição \& D. Cardoso 1262 (HUEFS); Palmeiras, 7 jan. 1997 (fr.), A.A. Conceição et al. 222 (SPF); Piatã, 3 nov. 2009 (fr.), M. Del-Rei et al. 91 (HUEFS); Quijingue, 1055'20''S, 3904'59'W, 8 jul. 2006 (est.), D. Cardoso et al. 1303 (HUEFS); Rio de Contas, 13³2'S, 415' 'W, 3 nov. 1988 (fl. fem. e fr.), R.M. Harley et al. 25898 (CEPEC, F n.v, MBM, SPF); Vitória da Conquista, 29 maio 2010 (fr.), A.F.P. Machado \& A.K.A. Santos 962 (HUEFS).

Odontocarya duckei foi descrita apenas com base na planta pistilada em fruto, sendo aqui descrita pela primeira vez os caracteres florais da planta estaminada.

\subsection{Odontocarya vitis (Vell.) J.M.A.Braga, Anales del}

Jardín Botánico de Madrid, 58(2): 359. 2001. Figuras 21E-J e 22.

Liana. Folhas subcoriáceas; pecíolo 3,5-6,5 cm compr., glabro, pulvino torcido na base; lâmina 6,5-10,5 × 4-8,5 $\mathrm{cm}$, elíptica a levemente ovada, base truncada a levemente cordata, margem inteira, ápice cuspidado a acuminado, face adaxial verde brilhante, face abaxial verde-claro-pálido, glabra; nervuras principais 5; domácias entre as nervuras principais e às vezes nas axilas das nervuras secundárias, abertura linear. Inflorescência estaminada axilar, racemo simples, raro panícula; raque 5-13 cm compr., glabra. Flo- 


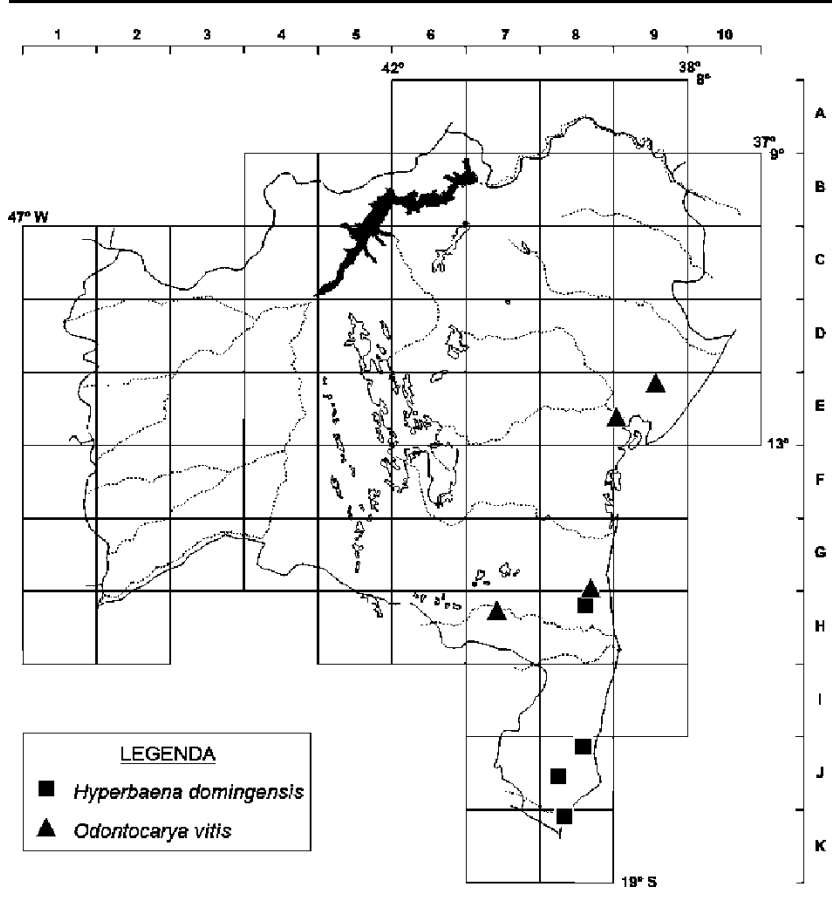

Figura 22. Distribuição geográfica de Hyperbaena domingensis e Odontocarya vitis no estado da Bahia.

res masc. creme-esverdeadas; pedicelo $2-4 \mathrm{~mm}$ compr., glabro; sépalas membranáceas, as 3 externas $0,5-0,7 \times 0,5-$ $0,6 \mathrm{~mm}$, ovadas a deltoides, as 3 internas $1,9-2,3 \times 2-2,2$ $\mathrm{mm}$, ovadas a suborbiculares, glabras; pétalas $0,3-0,6 \times 0,3-$ $0,6 \mathrm{~mm}$, glabras, margem inteira; 6 estames, $1,1-1,5 \mathrm{~mm}$ compr., filetes livres ou conatos na base, anteras rimosas. Inflorescência pistilada em racemo simples; raque ca. 21,5 cm compr., glabra. Flores fem. não observadas. Drupa 15$18 \times 10-13 \mathrm{~mm}$, elipsoide, imatura verde-escura, madura amarela a alaranjada; endocarpo 12-17 × 7-9 mm, face dorsal com tubérculos espiciformes, face lateral com depressões verticalmente escavadas, côndilo ventral 5-6 × 4-5,5 $\mathrm{mm}$, oblongo a levemente oval; semente 8-10 × 5-7 mm.

Endêmica do Brasil, ocorrendo em estados das Regiões Nordeste (BA) e Sudeste (ES e RJ) (Braga 2001, 2010). E8, E9, G8, H7, H8: Floresta Ombrófila Densa Submontana. Coletada com frutos em julho, agosto e novembro.

Material selecionado-Alagoinhas, 1 nov. 1998 (fr.), M.D.R. Orge et al. PL 620 (ALCB, HUNEBA); Buerarema, 21 jul. 1980 (fr.), A.M. de Carvalho et al. 279 (CEPEC); Cachoeira, 12³2'S, $39^{\circ} 05^{\prime}$ W, jul. 1980 (fr.), L. Scardino et al. in Grupo Pedra do Cavalo 443 (ALCB); Porto Seguro, 1652'02'S, 39²4'54”'W, 17 jul. 1997 (fr.), W.W. Thomas et al. 11591 (CEPEC, NY n.v.).

Odontocarya vitis difere das demais espécies de Menispermaceae estudadas (exceto $O$. duckei) por apresentar domácias entre as nervuras principais. Com folhas jovens, assemelha-se a $O$. duckei, porém estas espécies são facilmente distintas pelos caracteres apresentados na chave. Braga (2001), ao transferir Cissampelos vitis Vell. para Odontocarya, comentou que, apesar de Miers (1864) ter associado a espécie de Vellozo ao gênero Odontocarya, não publicou a nova combinação, preferindo estabelecer $O$. macrostachya Miers, considerado por Barneby (1970) como uma substituição ilegítima do binômio $C$. vitis.

\section{Orthomene Barneby \& Krukoff}

Arbusto escandente; caule volúvel. Folhas simples; pecíolo não peltado; lâmina coriácea a subcoriácea, venação palmatinérvea, nervuras principais geralmente 3 . Inflorescência estaminada axilar ou supra-axilar, racemosa ou flores solitárias; brácteas diminutas. Flores masc. diclamídeas; sépalas 6 em 2 séries, livres, geralmente coriáceas, as 3 externas pequenas, as 3 internas muito maiores, inseridas entre as externas; pétalas 6(-9), carnosas ou submembranáceas, muitas vezes como um disco ou com 3 ângulos formando uma pirâmide invertida, geralmente involuta, muitas vezes abraçando completamente o estame; estames 6, livres, eretos ou geralmente recurvados distalmente, anteras introrsas, deiscência transversal ou oblíqua. Inflorescência pistilada axilar ou supra-axilar, racemosa ou flores solitárias, às vezes ambas; brácteas diminutas. Flores fem. com perianto semelhante ao das masc.; estaminódios 6; carpelos 3. Drupa geralmente elipsoide, com pequeno apículo no ápice; epicarpo coriáceo; mesocarpo delgado ou ausente; endocarpo linear, lenhoso ou coriáceo, reticulado, côndilo lameliforme; semente linear, endosperma ruminado.

Orthomene está representado por quatro espécies, distribuídas na América Central (Panamá, Trinidad e Togado) e na América do Sul (Bolívia, Brasil, Equador, Guiana, Guiana Francesa, Peru, Suriname e Venezuela) (Barneby \& Krukoff 1971; Krukoff \& Barneby 1974; Krukoff 1976, 1982; Funk et al. 2007). No Brasil, o gênero está representado por três espécies com registro nas Regiões Norte, Nordeste, Centro-Oeste, Sudeste e Sul (Braga 2010). Na Bahia, o gênero apresenta apenas uma espécie.

\subsection{Orthomene schomburgkii (Miers) Barneby \&}

Krukoff, Mem. New York Bot. Gard. 22(2): 80. 1971. Figuras 24 e 25.

Arbusto escandente 3-11 m alt. Folhas levemente discolores; pecíolo 1-2 cm compr., glabro, pulvino geralmente não torcido no ápice; lâmina 5,5-12×3-5 cm, elíptica, base cuneada, margem inteira, ápice acuminado a levemente cuspidado, glabra; nervuras principais 3. Inflorescência estaminada às vezes em racemo simples, geralmente flores solitárias; raque ca. $5 \mathrm{~cm}$ compr., glabra. Flores masc. amarelas; pedicelo ca. $2 \mathrm{~cm}$ compr., glabro a incano; sépalas livres, glabras, margem inteira, ápice arredondado, as externas ca. $0,9 \times 1,1 \mathrm{~mm}$, ovadas, as internas 4-7 ×5-6 mm, largo-elípticas, côncavas; pétalas $6,1,8-2 \times 1,6 \mathrm{~mm}$, obdeltoides, carnosas, glabras, margem inteira; estames 22,2 mm compr., incurvados, anteras introrsas. Inflorescência pistilada em racemo simples, às vezes flores solitárias; raque 12-30 cm compr., glabra a incana. Flores fem. amarelas; pedicelo 8-25 mm compr., geralmente glabro, raro incano; sépalas glabras, margem inteira, ápice arredondado, as externas $0,8-0,9 \times 0,7-1,4 \mathrm{~mm}$, ovadas, as internas 3,2-6 6 3$5 \mathrm{~mm}$, largo-elípticas, côncavas; 6 pétalas, ca. $0,8 \times 0,7 \mathrm{~mm}$, obdeltoides, glabras, cobrindo $2 / 3$ dos ovários, margem in- 


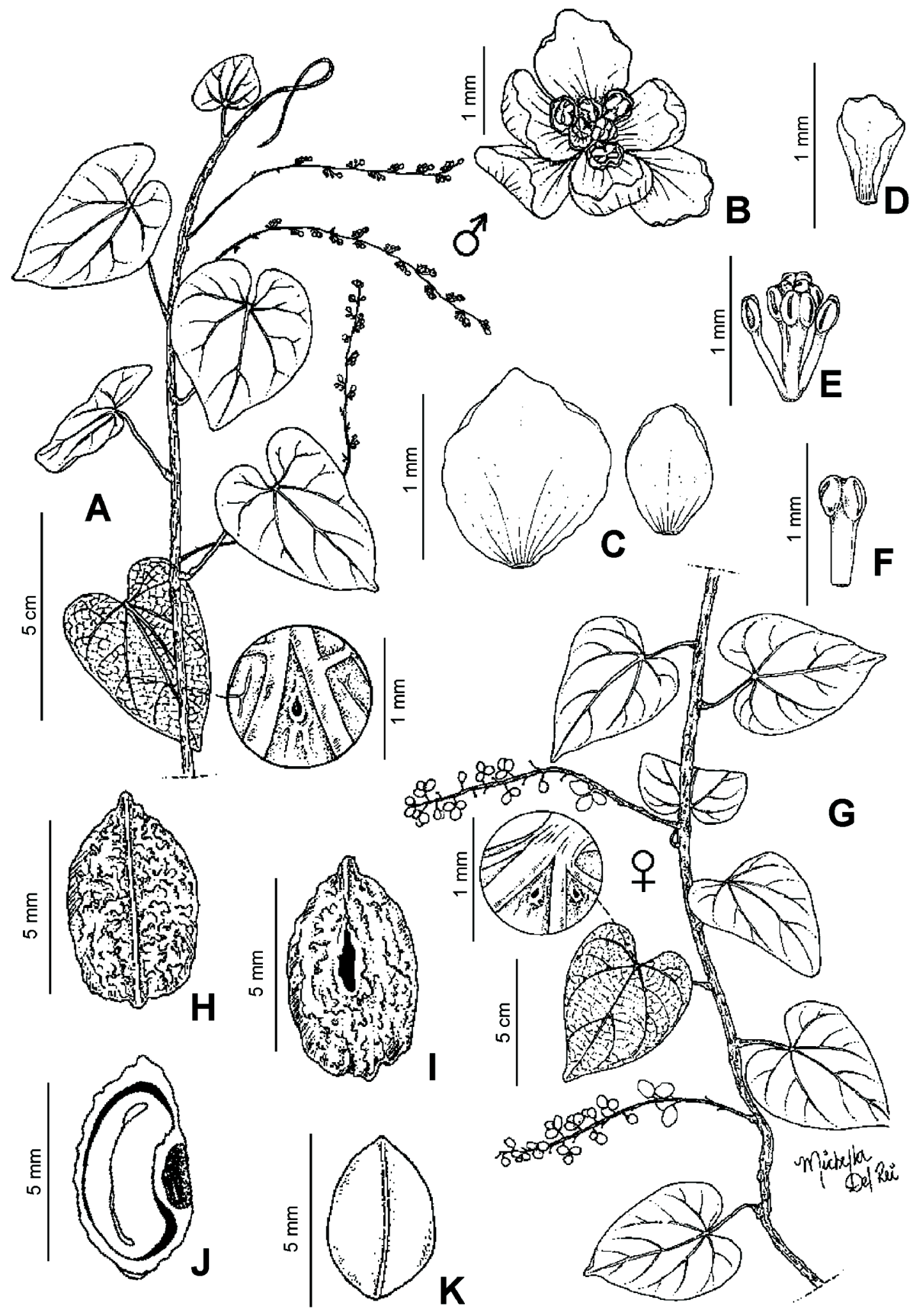

Figura 23. Odontocarya duckei: A- ramo com inflorescências estaminadas, com detalhes das domácias; B- flor masc., vista adaxial; C- sépalas, vista adaxial; D- pétala, vista adaxial; E- androceu; F- estame; G- ramo com infrutescências, detalhes das domácias; H- endocarpo, vista abaxial; I- endocarpo, vista ventral; J- endocarpo, corte longitudinal; K- endosperma (A-F- Harley 3477; G-K- Harley 22617). 
teira; estaminódios 1,5-1,6 mm compr., eretos, glabros; carpelos 1,9-2,2 × 1,2-1,3 mm, obovoides, ovário glabro, estigma flabelado, séssil. Drupa 30-35 × 12-14 mm, ca. $1,2 \mathrm{~cm}$ de espessura, elipsoide, madura alaranjada com máculas amarelo-claro; endocarpo $25-30 \times 9-10 \mathrm{~mm}$, elipsoide; semente ca. $23 \times 7 \mathrm{~mm}$.

Ocorre na América Central e do Sul (Barneby \& Krukoff 1971; Krukoff \& Barneby 1974, 1978; Krukoff, 1976, 1979, 1982). No Brasil, está distribuído em estados das Regiões Norte, Nordeste, Centro-Oeste, Sudeste e Sul (Barneby \& Krukoff 1971; Krukoff \& Barneby 1974, 1978; Barneby 1996; Krukoff 1976, 1982; Braga 2010). F8, G8, H8, I8: Floresta Ombrófila Densa Montana. Coletada com flores em junho e novembro e com frutos em janeiro e de junho a novembro.

Material selecionado - Arataca, $15^{\circ} 12^{\prime} 10^{\prime \prime} \mathrm{S}, 39^{\circ} 24^{\prime} 29^{\prime \prime} \mathrm{W}$, 21 jan. 2007 (fr.), R.A.X. Borges et al. 575 (CEPEC, RB); Camacan, 14 jul. 1978 (fr.), T.S. Santos \& L.A. Mattos-Silva 3317 (CEPEC, RB); Camamu, 18 jul. 2005 (fr.), A.M. Miranda 5165 (HST); Ilhéus, 27 nov. 1984 (fl. fem. e fr.), T.S. Santos 3958 (CEPEC, HUESC, HUEFS, MBM); Porto Seguro, 5 jun. 1962 (fr.), A.P. Duarte 6734 (RB); Una, $15^{\circ} 09^{\prime} \mathrm{S}, 39^{\circ} 05^{\prime} \mathrm{W}, 22$ set. 1992 (fr.), A.M.A. Amorim et al. 762 (CEPEC); Uruçuca, 1425' S, 3901'W, 25 ago. 1992 (fr.), A.M.A. Amorim 657 (CEPEC).

Como discutido anteriormente, Orthomene schomburgkii assemelha-se morfologicamente a Anomospermum reticulatum, podendo distinguir-se pelo pecíolo 1-2 cm compr., flor masc. com pétalas levemente menores que os estames, glabras, estames 2-2,2 mm compr., flor fem. com pétalas cobrindo parcialmente os ovários, cobrindo ca. 2/3 dos ovários e os estigmas e drupa elipsoide com endocarpo e semente lineares.

\section{Sciadotenia Miers}

Liana, raro arbusto. Folhas simples; pecíolo não peltado; lâmina concolor, cartácea a coriácea, glabra a levemente pubescente; venação palmatinérvea, nervuras principais 3-5. Inflorescência estaminada axilar, supra-axilar ou cauliflora, espiciforme, raro racemosa ou paniculada, pilosa; brácteas diminutas. Flores masc. diclamídeas; sépalas (6-)936 , em 4 a várias séries, as mais externas menores; pétalas 6 , geralmente côncavas, membranáceas, dorsalmente pubescentes; estames 6 , livres ou parcialmente conatos em sinândrio, conectivo estendendo-se além da antera, anteras introrsas, deiscência transversal. Inflorescência pistilada racemo curto, ereto ou pêndulo ou flores solitárias; brácteas diminutas. Flores fem. com perianto semelhante aos das masc.; estaminódio ausente; carpelos 6(9-15). Drupa vermelha ou alaranjada quando madura, obliquamente piriforme, cicatriz do estigma sub-basal, carpóforo presente; epicarpo coriáceo; mesocarpo mucilaginoso; endocarpo reniforme, encurvado ca. 3/4, crustáceo a coriáceo, côndilo ausente; semente curvada, endosperma ausente.

Sciadotenia está posicionado na tribo Tiliacoreae Miers (Diels 1910; nome corrigido em Forman 1982) e abrange 18 espécies distribuídas em alguns países da América Central
(Panamá) e da América do Sul (Colômbia, Equador, Guiana, Guiana Francesa, Peru e Venezuela) (Krukoff \& Barneby 1970b; Barneby \& Krukoff 1971; Krukoff 1982). No Brasil, são referidas 16 espécies ( 6 endêmicas), ocorrendo em estados da Região Norte, Nordeste, Centro-Oeste e Sudeste (Braga 2010). Sciadotenia está representado por duas espécies na Bahia.

\section{Chave para as espécies}

1. Subarbusto ereto; folha com 5 nervuras principais, todas livres na base; inflorescência estaminada em racemo simples; estames com filetes glabros .... 11.1. S. campestris

1'. Liana; folha com 5 nervuras principais, 3 unidas paralelamente ca. $3 \mathrm{~mm}$ na base; inflorescência estaminada em racemo composto; estames com filetes esparsamente pilosos na base 11.2. S. pubistaminea

\subsection{Sciadotenia campestris Barneby, Brittonia 44: 264.} 1992.

Figuras 8L-N e 25.

Subarbusto ereto $0,2-1 \mathrm{~m}$ alt.; ramo adulto estrigoso. Folhas cartáceas a levemente coriáceas; pecíolo $0,7-1,5 \mathrm{~cm}$ compr., glabro a levemente piloso no ápice; lâmina 4-6,9 × $2-4,5 \mathrm{~cm}$, ovada a elíptica, base subcordada, margem inteira, ápice mucronado a arredondado, às vezes levemente retuso, ambas as faces glabras ou levemente pilosas na base da lâmina e nervuras; nervuras principais 5 , todas livres na base. Inflorescência estaminada axilar, 1 ou 2 inflorescências por axila, racemo simples, com 7-10 flores frequentemente adensadas no ápice da raque; raque 2-3,5 cm compr., pilosa. Flores masc. creme; pedicelo $0,5-2 \mathrm{~mm}$ compr., densamente velutino; sépalas 15, 0,9-1,8 ×0,3-0,8 $\mathrm{mm}$, ovadas, lanceoladas a elípticas, levemente coriáceas, livres, face abaxial pilosa, margem inteira, ápice acuminado; pétalas não observadas; estames 6 , os 3 externos $0,6-0,7 \times$ ca. $0,2 \mathrm{~mm}$, com anteras estéreis, os 3 internos ca. 1,6 60,2 $\mathrm{mm}$, com anteras férteis, filetes glabros, anteras introrsas, deiscência transversal. Inflorescência pistilada e drupa não observadas.

Endêmica da Bahia ocorrendo apenas em cerrados do oeste do estado (Barneby 1992). E2, E3, F3: cerrado. Coletada com flores em maio, agosto e setembro.

Material examinado - Barreiras, 20 ago. 1986 (fl. masc.), G. Hatschbach \& J.M. Silva 50530 (holótipo MBM, isótipo USfoto); Correntina, 16 maio 2000 (fl. masc.), G. Hatschbach et al. 71238 (MBM).

Sciadotenia campestris é conhecida apenas pela planta estaminada. Esta espécie se diferencia de S. pubistaminea principalmente pelo hábito, sendo arbusto ereto com até $1 \mathrm{~m}$ de altura, folhas cartáceas a levemente coriáceas, pecíolo $0,7-1,5 \mathrm{~cm}$ compr. e flores masc. com estames pilosos, enquanto $S$. pubistaminea possui hábito lianescente, folhas membranáceas ou cartáceas, com pecíolos 1,5-3 cm compr. e flores masc. com estames glabros. 


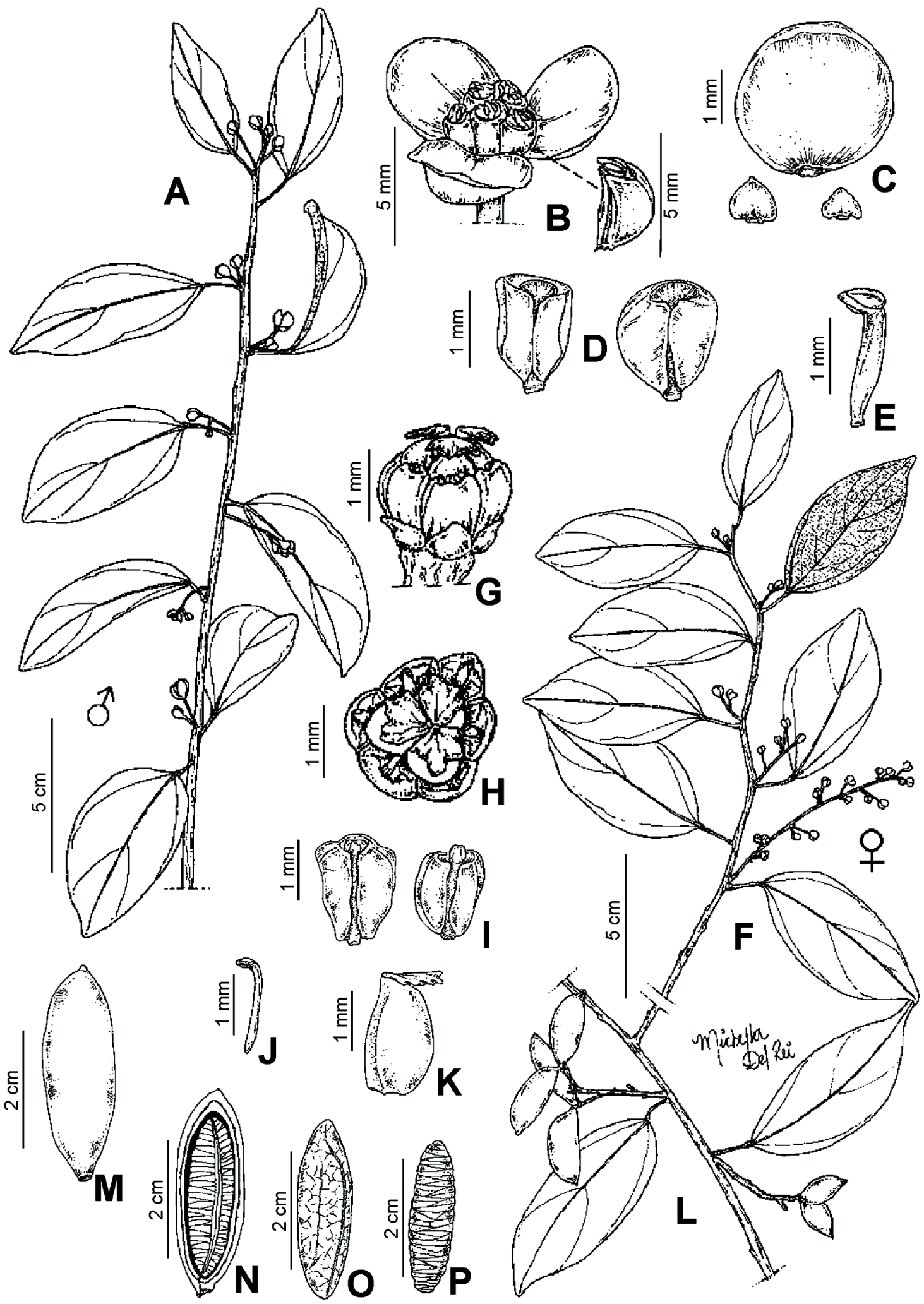

Figura 24. Orthomene schomburgkii: A- ramo com inflorescências estaminadas; B- flor masc., vista lateral; C- sépalas, vista adaxial; D- pétalas, vista adaxial; E- estame; F- ramo com inflorescências pistiladas; G- flor fem., vista lateral (sépala retirada); H- flor fem., vista adaxial (sépalas retiradas); Ipétala externa (esq.) e pétala interna (dir.), vista adaxial; J- estaminódio, vista lateral; K- carpelo; L- ramo com infrutescências; $\mathbf{M}$ - fruto; N- endocarpo, corte transversal; O- endocarpo; P- endosperma (A-E- Popovkin 448; F-K- Santos 3958; L-P- Amorim 657). 


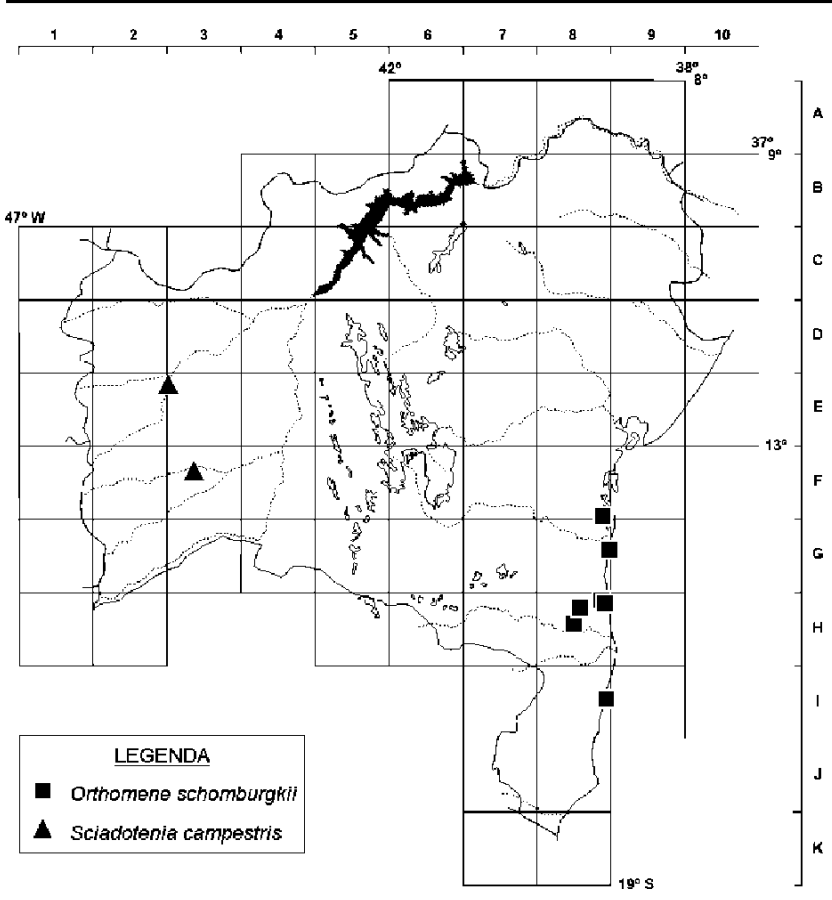

Figura 25. Distribuição geográfica de Orthomene schomburgkii e Sciadotenia campestris no estado da Bahia.

11.2. Sciadotenia pubistaminea (K.Schum.) Diels in Engler, Pflanzenreich 4(94): 85. 1910.

Figuras 2 e 26.

Liana 1-1,5 m alt.; ramo adulto glabro. Folhas cartáceas a membranáceas; pecíolo 1,5-3 cm compr., piloso; pulvino levemente torcido no ápice; lâmina 2,6-9 × 1,4-5,3 cm, elíptica, base subcordada a obtusa, margem inteira, ápice mucronado a retuso, face adaxial lustrosa, glabra, abaxial com nervuras pilosas; nervuras principais 5, 3 unidas paralelamente na base ca. $3 \mathrm{~mm}$, pilosas na base. Inflorescência estaminada axilar, racemo composto, geralmente curtofasciculado, 3-5 flores por fascículo, 5-7 flores frequentemente adensadas no ápice da raque; raque $1,5-7 \mathrm{~cm}$ compr., pilosa; Flores masc. alvas; pedicelo 0,5-1 mm compr., densamente velutino; sépalas 12, 1,5-2,2 × 1-1,3 mm, oblongas a ovadas, livres, membranáceas, face abaxial pilosa, margem inteira, ápice agudo; pétalas 3 , ca. $2 \times 0,7-0,9 \mathrm{~mm}$, oblongas, livres, membranáceas, dorsalmente pilosas, margem inteira; estames 6, os 3 externos ca. 2 mm compr., anteras estéreis, e 3 internos ca. 2,7 mm compr., filetes esparsamente pilosos na base, anteras introrsas, deiscência transversal. Inflorescência pistilada axilar, em racemo simples; raque 1,5-2,8 cm compr., pilosa. Flores fem. creme; pedicelo 2-4 mm compr., velutino; sépalas e pétalas iguais às das flores masc.; carpelos 6, ovários seríceos ou pilosos. Drupa ca. 9 $\times 7 \mathrm{~mm}$, obovoide, comprimida lateralmente, levemente convexa, velutina, carpóforo ca. $5 \mathrm{~mm}$ compr.; epicarpo membranáceo; endocarpo ca. $7 \times 5 \mathrm{~mm}$, obovado, fibroso.

Endêmica do Brasil, ocorre nos estados da Bahia e Minas Gerais (Krukoff \& Moldenke 1938; Krukoff \& Barneby 1970a; Krukoff 1979, 1982; Braga 2010). G7, H7: Floresta Estacional Semidecidual e Decidual. Coletada com flores em janeiro, março, maio e agosto e com frutos em agosto.

Material examinado - sem localidade, 16 jan. 1955 (fl. masc.), E. Pereira \& N. Pereira 6558 (RB); Encruzilhada, 15³0'54"S, 4048'51'W, 17 ago. 2001 (fl. .), A.M. Carvalho et al. 6981 (ALCB, CEPEC, HRB, HUEFS, HUESC, HUNEBA, SPF); Macarani, 2 ago. 1978 (fl. fem. e fr.), L.A. Mattos-Silva 187 (CEPEC, RB); Vitória da Conquista, 14²59'34"S, 4048'08'W, 22 mar. 1996 (fl. masc.), W.W. Thomas 11098 (CEPEC, NY n.v.).

Neste trabalho, é descrito pela primeira vez o fruto de Sciadotenia pubistaminea. Como discutido anteriormente, esta espécie pode ser confundida com $S$. campestris, diferenciando-se dela principalmente pelo hábito lianescente e estames pilosos.

\section{Telitoxicum Moldenke}

Liana lenhosa, escandente. Folhas simples; pecioladas, pulvino no ápice, levemente torcido; lâmina coriácea a subcoriácea, glabra; venação peninérvea. Inflorescência estaminada axilar ou cauliflora, geralmente paniculada, pubescente ou pilosa. Flores masc. verdes, diclamídeas; sésseis ou pediceladas; sépalas 6 , em 2 séries, as 3 internas maiores, membranáceas, imbricadas; pétalas 6 , geralmente membranáceas, formando um pseudodisco ligeiramente mais curto que as sépalas, margem plana a levemente involuta; estames 6 , eretos, livres ou adnatos à base das pétalas, antera rimosas. Inflorescência pistilada axilar ou cauliflora racemosa, pubescente ou pilosa. Flores fem. com perianto semelhante ao das masc.; estaminódios 6, levemente adnatos à base das pétalas, incurvados; carpelos 3, estigma séssil, ligulado, dilatado. Drupa obovoide ou oblongo-obovoide, levemente comprimida lateralmente; epicarpo coriáceo; endocarpo em forma de U invertido, coriáceo; semente curvada, endosperma ruminado (Barneby \& Krukoff 1971; Kessler 2003).

Telitoxicum está posicionado na tribo Anomospermeae Miers (Diels 1910; nome corrigido em Forman 1982) e possui oito espécies distribuídas na América do Sul (Brasil, Bolívia, Colômbia, Equador, Guiana, Guiana francesa, Peru, Suriname e Venezuela) (Barneby \& Krukoff 1971; Krukoff 1976, 1982). No Brasil, são referidas sete espécies (3 endêmicas), ocorrendo em estados das Regiões Norte e Nordeste (Braga 2010). Na Bahia, Telitoxicum está representado por uma espécie.

\subsection{Telitoxicum duckei (Diels) Moldenke, Brittonia 3: 42. 1938.}

Figura 13.

Liana; ramo adulto estriado, glabro. Folhas coriáceas a subcoriáceas; pecíolo $2,5-5 \mathrm{~cm}$ compr., com pulvino na base e no ápice, levemente torcido no ápice; lâmina 8-22 × 5-7,5 cm, elíptica, base cuneada, margem inteira, ápice mucronado, lustrosa, glabra; nervuras secundárias 6-8 pares. Inflorescência estaminada, pistilada e drupa não fo- 


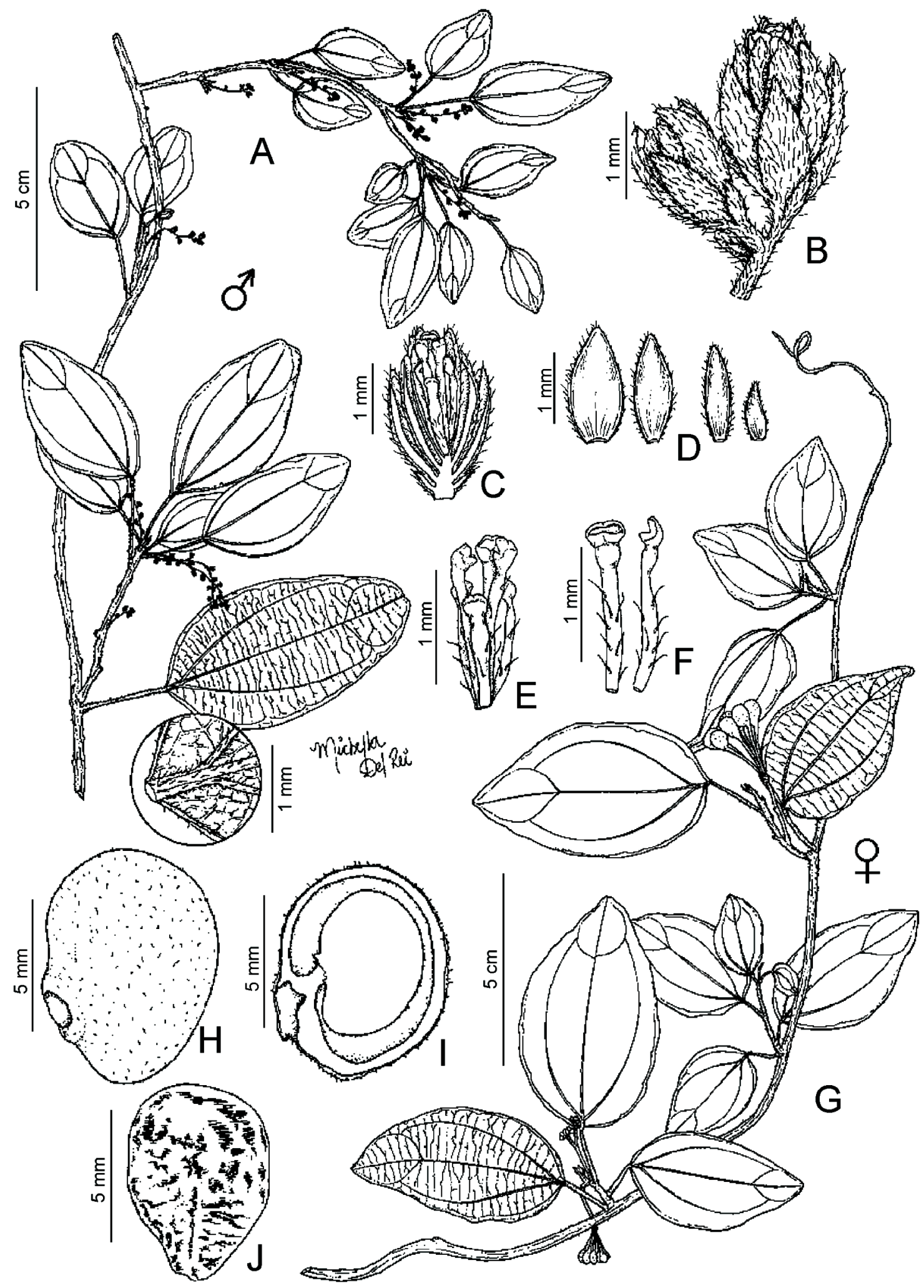

Figura 26. Sciadotenia pubistaminea: A- ramo com inflorescências estaminadas; B- detalhe de um ramo da inflorescência; C- flor masc., corte longitudinal; D- sépalas, vista adaxial; E- androceu; F- estames, vista adaxial (esq.) e lateral (dir.); G- ramo com infrutescências; H- fruto; I- fruto, corte longitudinal; J- endocarpo (A-F- Carvalho 6981; G-J- Mattos-Silva 187). 
ram observadas.

Telitoxicum duckei ocorre na América do Sul (Brasil, Colômbia e Peru) (Barneby \& Krukoff 1971; Krukoff 1982; Funk et al. 2007). No Brasil, está distribuída em estados das Regiões Norte e Nordeste (Braga 2010). G8: Floresta Ombrófila Densa Submontana. Coletada apenas com material estéril.

Material examinado - Ilhéus, 1447'21'’S, 3902'57' W, 16 mar. 1943 (est.), R.L. Fróes 12718/79 (NY-foto); Uruçuca, 14²5'24"'S, 3903'38'W, 21 mar. 1995 (est.), W.W. Thomas et al. 10834 (CEPEC, NY n.v.).

Material adicional examinado - PARÁ: s.l., 2 dez. 1907 (fl. masc.), A. Ducke 9012 (holótipo Abuta duckei B-foto, isótipo MGfoto).

Telitoxicum duckei distingue-se das demais espécies de Menispermaceae da Bahia pelas folhas com venação peninérvea com seis a oito pares de nervuras secundárias.

Coletas recentes de material estéril foram aqui identificadas como Telitoxicum duckei por comparação com a obra princeps e fotografias do holótipo e isótipo da espécie (Ducke 9012) e trabalhos anteriores que citaram a ocorrência da espécie no estado da Bahia (e.g. Krukoff \& Moldenke 1947; Krukoff \& Barneby 1970a; Barneby \& Krukoff 1971).

\section{Agradecimentos}

À CAPES, pela bolsa de Mestrado a MDRT e ao CNPq pela bolsa de Produtividade em Pesquisa a AMAA; aos projetos Flora da Bahia; aos professores e colegas da pós-graduação da Universidade Estadual de Feira de Santana; ao João Marcelo Alvarenga Braga, pela atenção e auxílio com a literatura; aos curadores dos herbários HUEFS e CEPEC e curadores dos demais herbários visitados, pelo empréstimo de material.

\section{REFERÊNCIAS}

Amorim, A.M.; Jardim, J.G.; Lopes, M.M.M.; Fiaschi, P.; Borges, R.A.X.; Perdiz, R.O. \& Thomas, W.W. 2009. Angiospermas em remanescentes de floresta montana no sul da Bahia, Brasil. Biota Neotropica 9: 313-348.

Barneby, R.C. 1970. Revision of neotropical Menispermaceae tribe Tinosporeae. Memoirs of the New York Botanical Garden 20: 81-158.

Barneby, R.C. 1975. Menispermaceae. In: R. Reitz (ed.), Flora Ilustrada Catarinense. Herbário Barbosa Rodrigues, Itajaí.

Barneby, R.C. 1992. A Sciadotenia (Menispermaceae) from the Brazilian Planalto. Brittonia 44: 264-265.

Barneby, R.C. 1996. Tiding of Menispermaceae from interior French Guiana and from the Brazilian State of Bahia. Brittonia 48: 20-25.

Barneby, R.C. \& Krukoff, B.A. 1971. Supplementary notes on American Menispermaceae, VIII. A generic survey of the American Triclisieae and Anomospermeae. Memoirs of the New York Botanical Garden 22: 1-90.

Barneby, R.C. \& White, P. 2004. Menispermaceae (Moonseed Family). In: N. Smith, S.A. Mori, A. Henderson, D.W. Stevenson \& S.V. Heald (eds), Flowering Plants of the Neotropics. Princeton University Press, Princeton, p. 247-249.

Braga, J.M.A. 2001. Cissampelos vitis Vellozo e o gênero Odontocarya Miers (Menispermaceae): complexidade taxonômica e nomenclatural. Anales del Jardín Botánico de Madrid 58: 358-360.

Braga, J.M.A. 2010. Menispermaceae. In: Lista de Espécies da Flora do Brasil. Jardim Botânico do Rio de Janeiro. Disponível em: http://floradobrasil.jbrj.gov.br/2010/ FB000163; acesso em 22 set. 2010.

Costa, F.N. \& Sano, P.T. 2007. Menispermaceae. In: M.G.L.
Wanderley, G.J. Shepherd, T.S. Melhem \& A.M. Giulietti (orgs), Flora Fanerogâmica do Estado de São Paulo. Vol. 5. FAPESP/Instituto de Botânica, São Paulo, p. 227235.

Diels, L. 1910. Menispermaceae. In: H.G.A. Engler (ed.), Das Pflanzenreich. Vol. 4, part 94. Wilhelm Engelmann, Leipzig, p. 1-345.

Forman, L.L. 1982. The correct names for the Tribes of Menispermaceae. Kew Bulletin 37: 367-368.

Funk, V.; Hollowell, T.; Berry, P.; Kelloff, C. \& Alexander, S.N. 2007. Checklist of the plants of the Guiana shield (Venezuela: Amazonas, Bolivar, Delta Amacuro; Guyana, Surinam, French Guiana). Contributions from the United States National Herbarium 55: 1-584.

Jacques, F.M.B.; Gallut, C.; Vignes-Lebbe, R. \& Zaragüeta i Bagils, R. 2007. Resolving phylogenetic reconstruction in Menispermaceae (Ranunculales) using fossils and a novel statistical test. Taxon 56: 379-392.

Judd, W.S.; Campbell, C.S.; Kellogg, E.A.; Stevens, P.F. \& Donoghue, M.J. 2007. Plant Systematics: a phylogenetic approach. 2 ed. Sinauer Associates, Sunderland.

Kessler, P.J.A. 1993. Menispermaceae. In: K. Kubitzki, J.G. Rohwer \& V. Bittrich, (eds), The Families and Genera of Vascular Plants. II. Flowering plants. Dicotyledons. Magnoliid, Hamamelid and Caryophyllid families. Springer-Verlag, Berlin, p. 402-418.

Krukoff, B.A. 1976. Supplementary notes on American Menispermaceae. XI. Neotropical Triclisieae and Anomospermeae. Phytologia 33: 323-341.

Krukoff, B.A. 1979. Supplementary notes on American Menispermaceae. XIV. Neotropical Triclisieae and Anomospermeae. Phytologia 41: 239-255.

Krukoff, B.A. 1982. Supplementary notes on American 
Menispermaceae. XVII. Neotropical Triclisieae and Anomospermeae. Phytologia 50: 80-111.

Krukoff, B.A. \& Barneby, R.C. 1970a. Supplementary notes on American Menispermaceae. VI. Memoirs of the New York Botanic Garden 20: 1-70.

Krukoff, B.A. \& Barneby, R.C. 1970b. Supplementary notes on American Menispermaceae. VII. Memoirs of the New York Botanic Garden 20: 71-80. 44

Krukoff, B.A. \& Barneby, R.C. 1974. Supplementary notes on American Menispermaceae. X. Lloydia 37: 2329.

Krukoff, B.A. \& Barneby, R.C. 1978. Supplementary notes on American Menispermaceae. XIII. Neotropical Triclisieae \& Anomospermeae. Phytologia 39: 283-293.

Krukoff, B.A. \& Moldenke, H.N. 1938. Studies of American Menispermaceae, with special reference to species used in preparation of arrow-poisons. Brittonia 3: 1-74.

Krukoff, B.A. \& Moldenke, H.N. 1947. Supplementary notes on American Menispermaceae IV. Bulletin of the Torrey Botanical Club 74: 378-382.

Macbride, J.F. 1938. Menispermaceae. Flora of Peru. Publications of the Field Museum of Natural History, Botanical Series 13: 680-699.

Mathias, M.E. \& Theobald, W.L. 1981. A revision of the genus Hyperbaena (Menispermaceae). Brittonia 33: 81104.

Nicolson, D.H. et al. 1991. Flora of Dominica Part 2: Dicotyledonae. Smithsonian Contributions to Botany 77: 2-156.

Ortiz, R. 2001. Menispermaceae. In: W.D. Stevens, C. Ulloa Ulloa, A. Pool, \& O.M. Montiel (eds), Flora de Nicaragua. Monographs in Systematic Botany from the Missouri Botanical Garden 85: 1432-1442.

Rhodes, D.G. 1962. Flora of Panama. Part IV. Fascicle V. Annals of the Missouri Botanical Garden 49: 157-160.

Rhodes, D.G. 1975. A revision of the genus Cissampelos. Phytologia 30: 415-484.

\section{Lista de Exsicatas}

Amorim, A.M.A. 657, 762 (10.1), 3931 (4.2), 4509 (5.1), 4856 (2.1), 4999 (4.1), 6571 (8.1); Anjos, B.A. 18 (4.2); Bandeira, F.P. s.n. ALCB 22735 (5.1); Bautista, H.P. 725 (5.4); Borges, R.A.X. 451 (4.1), 572 (4.2), 575 (10.1), 582 (7.2); Cardoso, D. 497, 549 (5.4), 1330 (9.1); Carvalho, A.M. 279 (9.2), 5774 (2.1), 6981 (11.2); Conceição, A.A. 222, 1262 (9.1); Costa, A.L. s.n. ALCB 1215 (5.5); DelRei, M. 43 (2.1), 44 (4.1), 45 (5.1), 50 (4.2), 51 (7.2), 52 (2.1), 53 (5.1), 55, 56 (5.4), 57, 58, 59 (5.2), 61 (4.2), 87 (5.4), 88 (5.2), 90 (5.5), 91 (9.1), 94 (5.2), 95, 97 (5.5), 100, 101 (5.4), 102 (5.2), 104 (4.2); Demuner, V. 619 (1.3), 1133 (1.2); Duarte, A.P. 5907 (5.1), 6734 (10.1); Ducke, A. 9012 (12.1); Eupunino, A. 15 (5.1), 397 (4.1); Ferrucci, M.S. 1010 (5.3); Fiaschi, P. 987 (4.1), 1089 (7.1), 1090 (4.1), 2595 (1.2); Folli, D.A. 2808 (1.1); França, F. 2170 (5.4); Fróes, R.L. 12718/79 (12.1); Ganev, W. 1236, 2527 (5.2); Gasson, P. 6022 (5.4); Guedes, M.L. s.n ALCB 26015 (5.1), 1465, 2082, 3344 (5.2), 4841 (5.5), 5258 (5.1), 10906 (5.4), 13582 (5.3), 14252 (5.1); Hage, J.L. 328 (5.1); Harley, R.M. 1548 (9.1), 2934 (5.5), PCD 3292 (9.1), 17354 (4.1), 17476 (4.2), 20530 (5.4), 20963 (5.2), 25898 (9.1), 27192 (5.2), 27550, 27755, 53863 (9.1); Hatschbach, G. 50130 (5.2), 50530 (11.1), 63017 (1.1), 63069 (4.2), 71238 (11.1), 78577 (5.2); Jardim, J.G. 351 (6.1), 390 (3.1), 609 (6.1), 1000 (7.2), 1031 (2.1), 1136 (5.1), 4363 (4.2), 4481 (7.1); Jesus, J.A. 524 (4.1); Kameyama, C. 73 (5.1); Lima, D.S. 72 (5.6); Lima, J. s.n. ALCB 6466 (5.2); Lima, S.S. 12 (5.1);
Lopes, M.M.M. 427 (2.1), 496 (5.1), 1374 (5.3), 1448 (8.1); Maas, P.J.M. 7064 (4.1); Machado, A.F.P. 962 (9.1); Macedo, G.E.L. 202 (4.1); Matos, F.B. 1686 (4.2); MattosSilva, L.A. 187 (11.2), 504 (4.1), 568 (3.1), 4787 (5.1); Melo E. 1340 (5.2), 1431 (5.4), 4021 (9.1); Mello-Filho, L.E. 2935 (4.1), 3033 (5.1); Miranda, A.M. 5165 (10.1); Mori, S.A. 9366, 9384 (4.1), 9825 (4.2), 10057 (9.1), 10840 (4.2), 11341, 12753 (4.1); Neves, M.L.C. 39 (4.1); Noblick, L.R. 2583 (5.1), 4234 (5.4); Nunes, A.T. 95 (5.1); Oliveira, R.P. 786 (6.1); Orge, M.D.R. PL 620 (9.2); Paixão, J.L. 299 (5.1) , 1172 (4.1), 1264 (2.1), 1282 (4.2); Passos, L. 358 (5.2); Perdiz, R.O. 353 (5.1); Pereira, E. 6558 (11.2); Pinheiro, R.S. 446 (4.1); Pinto, G.C.P. 31 (5.6), 672 (5.5); Pirani, J.R. CFCR 7259 (9.1); Queiroz, L.P. 1113 (5.4), 1166 (5.5), 2095 (5.2) , 4781 (5.5), 5501, 7666 (5.2); Ramos, C.E. 97 (4.1); Rapini, A. 1317, 1518 (5.4); Ribeiro, T. 207 (5.2); Rocha, D.S.B. 1025 (1.1); Rosas, E. 55 (4.2); Santos, T.S. 498 (4.1), 1038 (5.1), 1039 (7.2), 1143 (5.1), 1538 (8.1), 1646 (4.2), 1776, 1972 (5.1), 2106 (8.1), 2767 (5.1), 3187 (4.1), 3317 (10.1), 3477 (9.1), 3958 (10.1), 4345 (3.1), 4463 (5.1); Scardino, L. G.P.C. 443 (9.2), 874 (5.5); Senna, L.R. 141 (5.5); Souza, A.E.A. 33 (2.1); Souza, E.R. 110 (5.5); Souza, V.C. 29953 (1.1); Thomas, W.W. 6222 (6.1) 7190, 7222 (12.1), 9961 (7.1), 10024 (8.1), 10733 (1.1), 10834 (12.1), 11098 (11.2), 11461 (4.2), 11512 (4.1), 11591 (9.2), 12476 (4.1), 12635 (5.1); Valadão, R.M. 460 (4.1); Xavier, A.B. 232 (5.2). 